ELISABETE APARECIDA MONTEIRO

\title{
SOBRE UMA ESPECIFICIDADE DO ENSINO DA PSICANÁLISE NA UNIVERSIDADE: A FORMAÇÃO DE EDUCADORES
}

TESE DE DOUTORADO

UNIVERSIDADE DE SÃO PAULO

FACULDADE DE EDUCAÇÃO

SÃO PAULO - 2005 


\section{SOBRE UMA ESPECIFICIDADE DO ENSINO DA PSICANÁLISE NA UNIVERSIDADE: A FORMAÇÃO DE EDUCADORES}

Tese apresentada ao Programa de Pós-Graduação em

Educação, da Faculdade de Educação da Universidade de São Paulo, como requisito parcial à obtenção do título de Doutor em Educação, sob a orientação do Prof. Dr. Leandro de Lajonquière.

UNIVERSIDADE DE SÃO PAULO

FACULDADE DE EDUCAÇÃO

SÃO PAULO - 2005 
BANCA EXAMINADORA

Prof. Dr. Alberto Villani

Profa. Dra. . Eliane Marta Teixeira Lopes

Prof. Dr. José Sérgio Fonseca de

Carvalho

Profa. Dra. Walquíria Grant

Prof. Dr. Leandro de Lajonquière

(Orientador) 
As aulas recomeçaram seriamente no dia seguinte ao da chegada dos alunos. Lembro-me ainda da minha emoção quando o vozerio deu lugar ao mais profundo silêncio, à entrada do sr. Creakle. Ficou em pé no vão da porta, os olhos fixos em nós, como nos contos de fadas, quando o gigante vem examinar seus infelizes prisioneiros. Tungsby estava ao lado do sr. Creakle. Eu não compreendia porque ele gritava "Silêncio!" com voz tão feroz, pois estávamos todos mudos e imóveis, como que petrificados. Vimos moverem-se os lábios do sr. Creakle, e ouvimos Tungsby repetir as palavras seguintes:

- Meninos, eis um novo semestre. Vejam como vão se comportar. Ardor no estudo, é o que lhes aconselho, porque voltei cheio de ardor para castigá-los. Por mais que esfreguem, não apagarão as marcas do lugar onde eu lhes bater. E, agora, todos ao trabalho!

Tendo pronunciado tão horrível exórdio, Tungsby desapareceu e o sr. Creakle aproximouse de mim. Disse-me que ele também sabia morder; mostrou-me a bengala e perguntou-me o que eu pensava daquele dente? "É um dente canino, hein? É um dente grande, hein? Morde bem, hein?" E acompanhava cada pergunta com uma pancada que me obrigava a dobrar-me. Paguei assim, como disse Steerforth, o meu direito de cidadania na Instituição Salem.

\section{$(\ldots)$}

O colégio do dr. Strong era ótimo, e parecia tão pouco com o do sr. Creakle, quanto o bem se parece com o mal. Confiava-se em todas as circunstâncias na lealdade e sentimento de honra dos alunos. Essa confiança produzia os melhores resultados. Sentíamo-nos todos responsáveis pela fama do estabelecimento. Entregávamo-nos com toda a atividade ao estudo, a fim de contentar o dr. Strong. Divertíamo-nos a valer durante os recreios, e desfrutávamos ampla liberdade. Mas lembro-me de que gozávamos do bom conceito da cidade e nosso procedimento não prejudicava a reputação do colégio e de seu diretor. Quanto ao dr. Strong, era ele idolatrado pelos alunos e na verdade bem o merecia.

David Copperfield, Charles Dickens, 1849. 


\section{AGRADECIMENTOS}

Ao Prof. Dr. Leandro de Lajonquière, que há dez anos reveste de sensibilidade, amizade e generosidade as lições responsáveis por minha trajetória.

Aos professores que compuseram a banca de qualificação, Prof. Dr. Alberto Vilani e Prof. Dr. Rinaldo Voltolini, pelas preciosas observações que fizeram a pesquisa avançar.

Aos meus pais, Ayres e Lourdes, pela vida. 


\section{RESUMO}

A certeza da existência de um domínio que garanta o "bem fazer", apoiada na lógica do discurso universitário, caracteriza a pretensa "Pedagogia Científica" da atualidade. A demanda pelas teorias psicológicas (especialmente, as do desenvolvimento), o "professor reflexivo" (racional e explicativo) e o espaço conferido aos recursos tecnológicos vêm servir à lógica que anima o discurso pedagógico.

A maneira de a pedagogia compreender a educação, como aplicação dos princípios científicos que permitem o controle da aprendizagem, observa um racionalismo-cientificista, resistente à idéia de não saber inerente à relação do sujeito com o desejo, noção revelada pela psicanálise.

A resistência à aceitação dessa impossibilidade por parte daqueles impregnados do discurso pedagógico, bem como de um grupo maior de racionalistas-cientificistas, é explicada no fato de que o desejo sempre se revela après coup, então, reclama a renúncia à ideia clássica de controle e previsão.

O "problema" da Educação passa pela palavra e pelo fato de que 0 sujeito (falante ou ouvinte) está, por princípio, implicado em todo ato. A "verdade" da palavra, então, permite compreender a natureza da impossibilidade estrutural que a psicanálise descortina. Ela se relaciona com uma realidade inequívoca: a fala mediada pelo Outro. Portanto, em última instância, é o desejo que fala.

Em linhas gerais, os educadores devem extrair, essencialmente, duas contribuições da experiência com a teoria freudiana, sendo que a primeira abre caminho para a segunda: o conhecimento da constituição infantil e sobre si mesmos. No entanto, perseguindo uma relação de causalidade entre os meios pedagógicos utilizados e a previsão dos resultados, a pedagogia mantém-se resistente à noção de que o inconsciente possui um peso maior do que as intenções conscientes do educador.

A psicanálise possibilita compreender que sustentar a transmissão significa suportar, subjetivamente, a angústia de uma posição discursiva que 
exige a renúncia da onipotência narcísica e dos ideais de grandeza e de perfeição. Por isso, em oposição aos métodos (ao padrão), pode-se refletir sobre a questão do estilo na tarefa de cada educador.

O discurso pedagógico mantém a instituição educativa suspensa na ilusão. Seria necessário, portanto, renunciar a essa espécie de sustentação e dar lugar à realidade, lembrando Freud, ou, como a psicanálise permite ver, às infinitas faces da verdade.

A pesquisa ora apresentada tenciona demonstrar que a especificidade e a legitimidade do ensino da psicanálise a educadores repousa nas condições que vem oferecer para o resgate do sentido atualmente perdido da educação. 


\section{ABSTRACT}

The certainty of the existing domain that guarantees the assertion of an action, which could be called a "well done action", based on the academical speech coherence, characterizes the pretentious "Scientific Pedagogy" of the present time. The demand for psychological theories (specially, the ones concerning to development), the "reflective teacher" (rational and explanatory) and the space granted to the technological resources underlie the reason that encourages the pedagogical speech.

The way by which pedagogy understands education, as application of scientific beginnings that allow the control of learning, observes a scientific rationalism, resistant to the idea of non-lore, which is inherent to the relation between subject and desire, knowledge revealed by the psychoanalysis.

The resistance to the acceptance of this impossibility by those who are impregnated of the pedagogical speech, as well as by a larger group of scientific rationalists, is explained on the fact that the desire is always revealed après coup, claiming the renouncement to the classic idea of control and forecast.

The "problem" of Education goes through the word and the fact that the individual (speaker or listener) is, in beginning, implied in every action. The "truth" of the word, then, allows understanding the nature of the structural impossibility exposed by the psychoanalysis. It is linked to an unmistakable reality: the speech mediated by the other person. Therefore, ultimately, it is the desire that speaks.

In general lines, educators should extract, essentially, two contributions of the Freudian theory experience, having the first one make way to the second: the knowledge of children constitution and of themselves. However, pursuing a causality relationship between the practiced pedagogical ways and the forecast of results, pedagogy keeps on resistant to the notion that the educator's unconscious weighs more than his conscious intentions.

Psychoanalysis allows comprehending that sustaining transmission 
means to support subjectively, the anguish of a discursive position that demands the renouncement of the narcissistic omnipotence and the ideals of magnitude and perfection. Therefore, in opposition to the methods (to the pattern), the style in each educator's task can be thought.

The pedagogical speech keeps the educational institution held by illusion. It would be necessary, therefore, to renounce this sort of sustentation and give place to reality, or, as psychoanalysis shows, to the infinite faces of the truth.

In this present research it is intended the demonstration that the specificity and the legitimacy of the psychoanalysis teaching to educators lies on the conditions it offers for the rescue of the lost sense in education. 


\section{SUMÁRIO}

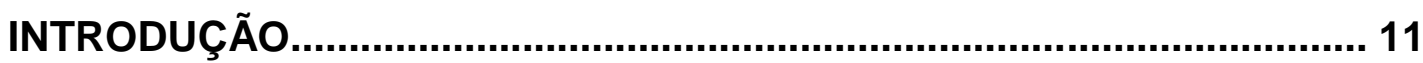

CAPÍTULO I - DO RACIONALISMO AO CIENTIFICISMO: O DISCURSO

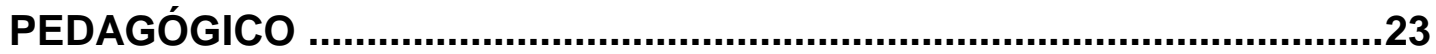

O contexto: a assim chamada "sociedade do conhecimento" 27

Tecnologias e descobertas científicas a serviço de uma "educação adequada". 29

Desenvolvendo a capacidade de pensar ou o "aprender a

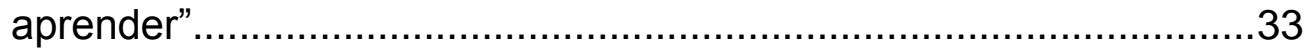

A leitura cientificista do construtivismo .............................................. 34

O conceito de "professor reflexivo" na formação de educadores...... 37

Desenvolvimento de capacidades e inserção profissional: finalidades da educação? 42

\section{CAPÍTULO II - A PSICANÁLISE FRENTE À SUMMA DILIGENTIA DA UNIVERSIDADE: O RACIONALISMO CIENTÍFICO ................................ 52}

Os novos paradigmas científicos: o inconsciente e o átomo............... 56

A psicanálise sob o olhar da epistemologia das ciências .................. 61

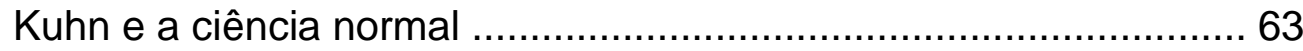

Progresso e racionalidade em Larry Laudan ................................... 67

A psicanálise como contraciência ................................................. 70

O empirismo lógico e os "psicanalistas do comportamento" nos

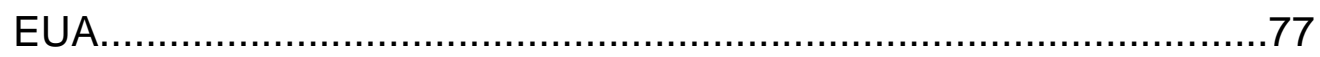

Naturwissenschften: entre o desejo pela cientificidade e a natureza do objeto ............................................................................... 81

O discurso da universidade versus uma teoria fictícia....................... 89 
CAPÍTULO III - SOBRE O ESTILO: A TRANSMISSÃO DA PSICANÁLISE

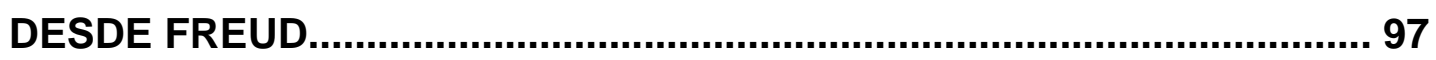

O método dogmático e o método genético na transmissão da

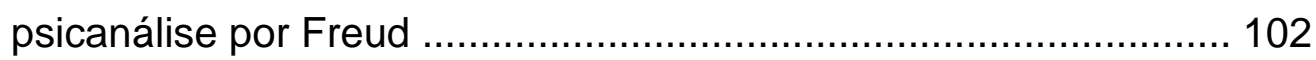

Da transmissão à formação: as instituições psicanalíticas ............. 107

O ensino da psicanálise: estilo e invenção ...................................... 122

Lacan e Laplanche na universidade ........................................... 129

CAPÍTULO IV - UMA ESPECIFICIDADE NA FORMAÇÃO DE

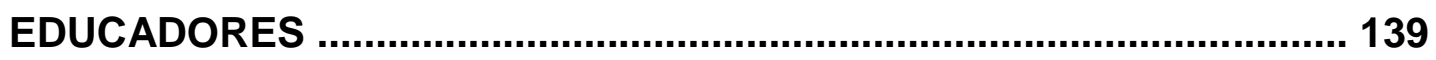

Psicanálise, ou o terceiro na formação de educadores .................. 155

$\mathrm{O}$ eu do sujeito versus o sujeito do inconsciente ou, a especificidade freudiana 162

CONSIDERAÇÕES FINAIS 167

BIBLIOGRAFIA 172 


\section{INTRODUÇÃO}

Na história da psicanálise, há inúmeros momentos em que a questão da transmissão da descoberta psicanalítica se constituiu em foco de reflexão. Em 1918, por exemplo, provavelmente em razão do Quinto Congresso Psicanalítico Internacional que ocorreu em Budapeste, Freud escreveu Sobre o Ensino da Psicanálise nas Universidades. Em 1919, Ferenczi foi nomeado professor de psicanálise na Universidade de Budapeste, onde havia uma grande agitação dos estudantes de medicina quanto à inclusão da psicanálise no currículo, movidos que estavam por uma exigência de verdade, de revelação. $O$ título do texto em húngaro traduz-se por: "Deve a Psicanálise ser ensinada na universidade?" Nesse texto, Freud mostrou-se a favor do ensino da psicanálise no curso de medicina descrevendo duas etapas do curso, que seriam: uma etapa elementar (introdutória) a todos os estudantes de medicina, em que se trataria detalhadamente das relações entre vida mental e vida física, e outra de aulas especializadas para psiquiatras. Além disso, e para além do campo dos distúrbios psicológicos, Freud afirma a contribuição da psicanálise na solução de problemas da arte, da filosofia e da religião:

Os efeitos fecundadores do pensamento psicanalítico sobre essas outras disciplinas certamente contribuiriam muito para moldar uma ligação mais estreita, no sentido de uma universitas literarum, entre a ciência médica e os ramos do saber que se encontram dentro da esfera da filosofia e das artes. (1919 [1918], 1988, p. 188-9)

Lendo o texto citado acima, é possível depreender das palavras de 
Freud que assim como o que se ensina na universidade não é suficiente para a formação de especialistas e, por isso, os recém formados devem procurar aperfeiçoamentos (Freud usa o exemplo dos estudantes de medicina que pretendem se dedicar às cirurgias), também no que se refere à psicanálise, o objetivo do ensino universitário seria de que o estudante aprendesse algo sobre a psicanálise e que aprendesse algo a partir da psicanálise. Deduz-se que aprender algo sobre e a partir da psicanálise não atende à "capacitação" para a prática da clínica psicanalítica, nem ao conhecimento mais profundo e abrangente do desenvolvimento da teoria, mas introduz o estudante (o de medicina é apenas um exemplo) a uma compreensão específica, a uma perspectiva de homem que ultrapassa a biológica.

Mesmo que aparentemente a universidade se apresente como um espaço privilegiado e passível de comportar o ensino da psicanálise, ainda hoje a pergunta originariamente em húngaro, permanece. Isto, pode-se antecipar, parece ser devido a uma diferença fundamental entre, por um lado, o discurso que rege o pensamento nas universidades e, por outro, o discurso psicanalítico.

Em primeiro lugar, apesar de serem distintos (conforme se verifica nas proposições de Lacan), é sabido que o discurso da ciência norteia o discurso universitário e, isto quer dizer que a universidade se apóia no pressuposto de que é possível construir um saber sobre a verdade. Enquanto que, nas palavras de Mário Fleig, "o discurso psicanalítico nos evidencia que, apesar dos efeitos da verdade inconsciente estarem se revelando em ato, a cada verdade não corresponde necessariamente um saber" (1998, p. 33). Para evidenciar o mesmo distanciamento, é possível destacar o pensamento de Maud Mannoni quanto à especificidade da formação do analista, ressaltando a experiência analítica do aprendiz enquanto paciente e, depois, como analista: "Assim, o saber se estende de uns aos outros sem que se possa falar de comunicação. No quadro universitário, ao contrário, o ensino limita o que pode comunicar, de acordo com as regras deste quadro" (1989, p. 84).

Se Freud sublinhou a possibilidade de que os universitários aprendam algo sobre e a partir da psicanálise, na polêmica em torno dos cursos ou 
disciplinas de psicanálise, talvez coubesse uma análise nas concepções de ensino e de transmissão. Até certo ponto, a psicanálise parece poder ser enquadrada no contexto do estilo acadêmico, porém, não formaria analistas, já que neste caso há ainda a supervisão e a análise pessoal. Na perspectiva de Octave Mannoni (1982), surge daí uma primeira diferença, a saber: o ensino enquanto informação não deveria causar certos efeitos particulares sobre os discípulos, pois o ensino acadêmico está organizado para defender-se contra esses efeitos. A defesa contra tais efeitos poderia levar a uma deformação da teoria psicanalítica, na medida em que a conduziria para certeza universitária. O risco de se desnaturalizar, de se desarmar e neutralizar o discurso perturbador de Freud a partir da crescente difusão da teoria, também é considerado por Piera Aulagnier (1990).

Deve-se colocar, então, a pergunta sobre a possibilidade do ensino da psicanálise. Isto porque, quando se pensa na transmissão da psicanálise, dois importantes fatores são considerados: o ambiente transferencial em que a transmissão ocorre e o saber que se transmite e que se encontra atrelado ao inesgotável e inatingível saber inconsciente. Por isso, por não comportar estes dois fatores mutuamente supostos (ou talvez, por não reconhecê-los), é que a transmissão da psicanálise na universidade ainda é bastante polêmica. Disso se poderia deduzir que: os limites da universidade comportam o ensino (cujo resultado é previsto) e não a transmissão (e seus efeitos) da teoria psicanalítica.

Avançar nesta constatação implica em, inicialmente, compreender que não há qualquer possibilidade de verificação objetiva da psicanálise, ou melhor, não é possível estabelecer uma construção teórica sobre o inconsciente nos moldes da ciência positiva, referendada pelo discurso universitário. Apoiando-se em Lipps ${ }^{1}$ (1897), em A Interpretação de Sonhos (1900), Freud diz que o problema do inconsciente é menos um problema psicológico do que o problema da psicologia:

É essencial abandonar a supervalorização [presente na psicologia] do estar consciente para que se torne possível formar uma opinião correta da origem do psíquico. (...) deve-se pressupor que o inconsciente é a base

\footnotetext{
${ }^{1}$ Theodor Lipps (1851-1914) era um professor de Munique que escrevia sobre psicologia e estética, e ao qual se atribui a introdução do termo Einfühlung (empatia).
} 
Lacan expõe a mesma condição que caracteriza o objeto da psicanálise, como se é possível observar no Seminário 5 (1957-1958), As Formações do Inconsciente:

\begin{abstract}
Digamos que tudo o que é da ordem do inconsciente como estruturado pela linguagem coloca-nos diante do seguinte fenômeno: não é nem o gênero nem a classe, mas tão-somente o exemplo particular que nos permite apreender as propriedades mais significativas. (...) Há nisso uma inversão de nossa perspectiva analítica habitual, no sentido da análise das funções mentais. Poder-se-ia chamá-la de fracasso do conceito, no sentido abstrato do termo. Trata-se, mais exatamente, da necessidade de passar por uma forma que não a da apreensão conceitual. (...) Considerando o terreno em que nós nos colocamos, mais do que pelo uso do conceito, é por uma distorção do conceito que somos obrigados a proceder. (1999, pp. 69-70)
\end{abstract}

Superficialmente, pode-se dizer que o conhecimento sobre 0 inconsciente não carrega consigo uma lógica preestabelecida, por isso, tampouco possibilita um saber a priori sobre suas produções.

Lacan ensinou psicanálise na universidade e, segundo Roudinesco (1977), procurou formalizar o ensino sobre o inconsciente nos moldes dos ideais da ciência oficial, adotou as proposições da ciência lingüística e criou os matemas, chegando a buscar a fórmula axiomática da psicose, da neurose e da perversão. Mesmo assim, é possível afirmar que Lacan não adulterou o ensino sobre o inconsciente (o saber do qual trata a psicanálise), conceitualizando-o (ou mesmo isolando-o materialmente), aliás, considerava-se um poeta antes de um cientista. Cabe lembrar que quando Lacan afirma não ser lacaniano não atende à demanda universitária, pois se nega a ocupar a posição do Eu Ideal, do Eu que domina, em que está situada a verdade do discurso universitário a qual, pelo enunciador, "a coisa é idêntica a si mesma", desencadeando na certeza sobre seu conhecimento, um conhecimento, portanto, estabelecido.

A aproximação da psicanálise com outros saberes participou dos planos de Freud. Basta lembrar que a esperança de que o esclarecimento trazido pela Psicanálise pudesse alcançar a profilaxia mais radical das neuroses acompanhou-o por um longo tempo, como se verifica em As Perspectivas Futuras da Terapêutica Psicanalítica, de 1910, mas se revelou 
um engano, quando se reconheceu uma tendência "natural" do homem à neurose, ou ainda, a necessidade da repressão no desenvolvimento da civilização. Atualmente, permanece o interesse em estabelecer contribuições psicanalíticas a outros campos do conhecimento, dentre eles a educação. No entanto, também permanecem indefinições sobre a maneira pela qual tais contribuições possam acontecer.

Há, sem dúvida, muito que aprender do conjunto teórico estabelecido na obra psicanalítica desde Freud. No entanto, a teoria psicanalítica não se localiza no rol dos saberes diretamente aplicáveis, no sentido em que não oferece previsões e domínios técnicos da realidade. Como diz Maria Lúcia Romera: "Mas, se ao cavalo selvagem não se faz a domagem, ao inconsciente não se ditam regras, não se o normatiza e ele aparece, exigindo vitória. Não avisa que chega, não bate à porta, só resta saber o rumo tomado" (1994, p. 57-8). A psicanálise, o estudo do inconsciente, trabalha com um saber a posteriori, desta forma se distancia da pretensão de controle científico. Em outras palavras, há uma particularidade no ensino da psicanálise, isto é, para além da escrita psicanalítica há uma "reinvenção" ou uma produção da teoria na realidade, definida como uma teoria fictícia (Mannoni, 1989).

Talvez seja possível antecipar que é justamente devido ao seu caráter fictício que a psicanálise não atende ao que se preconiza no discurso predominante do campo educativo, a saber, o discurso pedagógico atual. É necessário considerar que a formação de educadores se encontra predominantemente nos limites dos saberes universitários e segue preferencialmente as proposições da pedagogia, que se constitui num apanhado de discursos que se pretendem científicos, racionais, lineares, cujas leituras da realidade abrem possibilidades de orientações para as práticas escolares e rejeitam a idéia do não saber.

Há uma preocupação evidente na pedagogia de hoje em alcançar os acertos e evitar os erros. Isso conduz a uma crença na possibilidade de controle dos resultados, oferecido pelas descobertas científicas. Os 
pedagogos de hoje estão convictos de que o conhecimento científico possa trazer controles sobre a aprendizagem, a disciplina e o desenvolvimento (entre outros fatores), isto é, que possa garantir, como diz Mireille Cifali, o "fazer bem" (1999, p.139).

A certeza sobre a existência de um domínio que garanta o "fazer bem" é gerada pela lógica do discurso universitário, no qual a pedagogia está mergulhada. Assim, aquilo que a pedagogia de hoje compreende como ação educativa, a saber, a aplicação de preceitos científicos que ofereçam o controle da aprendizagem, respeita uma racionalidade marcante, enquanto que o ensino da psicanálise conta com os pontos de não saber inerentes à relação do sujeito com o desejo.

É possível que se deduza daí uma importante divergência entre o discurso pedagógico e o discurso psicanalítico. Quando se pensa no educar, parte-se de uma determinada concepção de sujeito para o qual a educação se dirige e o que, em última instância, se transmite (para além do ensino e da informação). Em primeiro lugar, a psicanálise possui uma determinada concepção de sujeito que se distancia do modelo científico, portanto, dos pressupostos da pedagogia (Ferretti, 1997). Em segundo, para a psicanálise, a transmissão de conhecimentos não ocorre isoladamente da transmissão de um "certo" saber, tampouco pode ser pensada alheia à transferência e, nessa perspectiva, a idéia de ensino sem efeitos (universitário ou não) não se sustenta.

A estrutura do encontro entre os sujeitos na educação é a mesma da análise, apesar de guardar suas especificidades. Ela ocorre quando o sujeito $^{2}$ supõe a um outro o saber sobre o desejo (a transferência), portanto, atribuindo-lhe o poder de revelar aquilo que lhe falta - o objeto $a^{3}$ - que o coloca na posição desejante. "Freud também indica que [análise e educação] têm em comum um meio de ação: o poder de sugestão conferido pelo amor que a criança, ou o paciente, dirige ao educador (ou analista)" (Millot, 1995, p. 127). O poder de sugestão provém do lugar em que

\footnotetext{
${ }^{2}$ Sujeito porque se encontra sob o registro da castração e que, como um ser em falta, é, nas proposições lacanianas, o sujeito do desejo (desejo inconsciente, portanto, sujeito do inconsciente). 3 "Termo introduzido por Jacques Lacan, em 1960, para designer o objeto desejado pelo sujeito e que se furta a ele a ponto de ser não representável, ou de se tornar 'resto' não simbolizável" (Roudinesco; Plon, 1998, p. 551)
} 
educador e analista são colocados: ideal-do-eu. No entanto, enquanto o educador deve sustentar tal posição para que, pelo fornecimento de certos traços identificatórios (via di porre), o educando possa situar-se pelo domínio do princípio da realidade; o analista, por outro lado, busca sua destituição do ideal-do-eu de seu paciente, dissolvendo a transferência (via di levare).

Se por um lado não há saber sobre o desejo, por outro é essa condição de não saber, de dependência em relação ao outro, que coloca o sujeito em condição de participar da transmissão "de um conjunto parcial de conhecimentos ou uma amostra daquilo que os outros souberam acumular com antecedência" (Lajonquière, 1999, p. 167). Na medida em que um (aluno) reclama ao outro (professor) o saber sobre o desejo, esse outro lhe oferta os conhecimentos (epistéme) pelos quais perpassam tantas outras coisas: "Mais ainda, cabe concluir que educar não é nada mais que o corriqueiro pôr em ato de um processo de filiação ou assujeitamento a ideais, desejos, sistemas epistêmicos e dívidas [simbólicas]" (idem, p. 173).

A maneira psicanalítica de compreender a educação diverge do discurso racional da pedagogia, pois o processo ensinar-aprender, segundo a psicanálise, está submetido às singularidades (intérminas) de cada um dos sujeitos envolvidos. Isto quer dizer que o ensino da psicanálise, como qualquer outro, além de assumir uma ou outra configuração dependendo do sujeito para quem for dirigido, não possibilita determinar a configuração dessa realidade que se apresenta interior, singular e que, principalmente, não é, tampouco estará pré-constituída. Em resumo, não há previsões assim como não há conhecimento direto e antecipado sobre a realidade com a qual se trabalha. Também porque, essa realidade não é pré-existente ao encontro educativo.

É das proposições psicanalíticas sobre a estrutura da ação educativa (o desejo de saber e a transferência), da reflexão em torno da afirmação freudiana sobre a impossibilidade de educar (juntamente com outras duas profissões: curar e governar) que a educação pode extrair a contribuição psicanalítica. No entanto, submetida ao discurso pedagógico, parece que tal conhecimento se the mostra pouco interessante ou desviante, pois não pode convertê-lo em algum método, algum controle da realidade. Já que as lições de Freud nos mostram que não há controle do professor sobre aquilo que 
ensina, tampouco sobre o aluno.

Mireille Cifali, em L'Infini Éducatif: Mise en Perspective (1986), de maneira muito interessante, recupera as tentativas de contribuição ao campo da educação que partiram do segmento tradicionalmente mais céptico, mais supostamente científico da história da psicologia, representada por William James e, também, por Claparède. Em seu estudo, mostra como os esforços em retirar a educação do rol das artes a fim de conceder-lhe o status de ciência resultaram em conclusões surpreendentes, tais como: de que a psicologia científica não é capaz de oferecer a ajuda que os pedagogos esperam dela, ou ainda, de que apenas uma pesquisa da verdade, afastada de um ceticismo estéril poderia no futuro criar perspectivas para fortalecer a educação. Hoje, vivendo o futuro em relação a estes autores, verifica-se que no campo da educação segue (e seguirá) a ausência de regras fixas, de dogmas, a impossibilidade de previsões e métodos que garantam seu sucesso. Por uma (simples?) razão, a educação é fundamentalmente um encontro com o outro. Cada outro traz uma realidade desconhecida, um mundo de incertezas.

O estudo da transferência mostra que o encontro entre professor e aluno não se restringe no encontro entre dois outros, mas no encontro entre vários outros que habitam a subjetividade do professor e outro tanto de outros que habitam a subjetividade do aluno. Em suma, o conceito psicanalítico de transferência revela a impossibilidade de existir um controle dos efeitos produzidos pelo encontro educativo. Mais ainda, revela que 0 encontro é sempre um desencontro.

Cifali elabora uma preciosa e inquietante reflexão: "Ninguém reduzirá no futuro esta impossibilidade, nosso progresso somente será de entendê-la não como uma infelicidade, mas como constitutiva da nossa relação ao outro-sujeito" (1986, p. 154). Noutras palavras, na educação operam os mesmos limites caros à compreensão do sujeito pela psicanálise.

Retornando à questão do ensino da psicanálise na universidade, especificamente na formação de educadores: a mesma distância que se 
coloca entre o discurso psicanalítico e o universitário, interpõe-se na concepção de educação para a psicanálise e para a pedagogia, isto é, podemos pensar em ensinar, seja psicanálise ou qualquer outra disciplina, sem causar efeitos? Há possibilidade de se transmitir algo sem estar subjetivamente implicado no processo? Em 1914, no texto Algumas Reflexões sobre a Psicologia do Escolar, Freud indica que a figura do professor não passa despercebida. Sendo admirado, criticado ou rejeitado, efeitos que apontam para o seu lugar na economia psíquica do aluno e não para a sua pessoa.

Percebe-se que a contribuição que a psicanálise pode oferecer à formação de educadores segue na contramão daquilo que o discurso pedagógico valoriza e pelo qual anseia. Nisto repousa a idéia da especificidade do ensino da psicanálise.

A pesquisa ora apresentada pretende demonstrar a premissa desdobrada nos seguintes tópicos:

- A psicanálise constitui um corpo teórico que possibilita à educação uma "outra forma de pensar", desaprisionando-a da busca infrutífera pelo conhecimento absoluto e pelo controle da ação educativa. Logo, o ensino da psicanálise aos educadores não se limita a uma contribuição, mas apresenta-se como a possibilidade de que a educação seja resgatada de um imobilismo ou de "malabarismos" estéreis;

- Opondo-se ao descrédito pretensamente científico que ainda possa representar resistências à sua inserção na formação de professores, ou que venha conferir-lhe, aí, um papel secundário, a psicanálise, que não se traduz no discurso das ciências positivas e não obedece ao discurso universitário, faz ver a educação submetida à mesma lei: da impossibilidade do desejo;

- Assim, a teoria psicanalítica não é apenas uma contribuição legítima à educação, como também necessária, especialmente nos dias de hoje, quando o sentido da educação é encoberto pelas ilusões que alimentam o discurso pedagógico atual.

lluminados pelo estudo da teoria psicanalítica e, não menos importante, por uma longa trajetória de vida escolar (discente e docente) 
marcada por um entusiasmo pelas questões que cercam a responsabilidade de educar, os fundamentos que sustentam a afirmação acima foram dispostos ao longo de quatro capítulos:

No primeiro capítulo, é tecido um panorama dos atuais paradigmas na formação de educadores. Tomando o discurso pedagógico como instância que arbitra sobre os vários rumos que a educação tem tomado, dentre eles a pesquisa e a formação, esse capítulo destaca alguns contextos que alimentam a idéia de uma "Pedagogia Científica", tais como: a adequação ao cenário global que se traduz por "sociedade do conhecimento"; a transmissão mais adequada, que se faz por meio dos recursos tecnológicos e demais descobertas científicas; a educação adequada ao mercado de trabalho; o lema do "aprender a aprender", resultante das descobertas científicas sobre os processos cognitivos que pretensamente habilitam o professor à tarefa de "ensinar a aprender"; a abordagem cientificista na tônica dada às teorias construtivistas; o "educador reflexivo", que se debruça sobre o saber hipercomplexo, a partir do qual se pretende representar a pedagogia atual.

Nessa direção, procura-se evidenciar as convergências com a definição do discurso da pedagogia que este trabalho apresenta: o racionalismo cientificista. No fechamento do capítulo inicial, faz-se uma retomada do sentido original da educação, contrastando-o com os desvios provenientes da pretensa "Pedagogia Científica".

No segundo capítulo, são apresentadas diferentes leituras em torno do estatuto epistemológico da psicanálise, uma polêmica que acompanha a pergunta sobre a legitimidade de seu ensino na universidade, território privilegiado do desenvolvimento e da transmissão da ciência. Propõe-se evidenciar alguns dos posicionamentos presentes no interior da própria "instituição psicanalítica" acerca do seu lugar no campo epistemológico. Paralelamente, e dentro dos limites deste trabalho, são abordados alguns debates provenientes da Filosofia da Ciência que dividem a compreensão dos critérios impostos às teorias para que tenham ou não o mérito científico; seu "contraponto", a Epistemologia da Ciência, procurando explicitar em cada disciplina seus critérios e seu regime de validação; acrescentam-se, ainda, alguns autores com posicionamentos singulares. 
A importância da discussão proposta no segundo capítulo consiste em colocar em evidência o que sustenta a resistência em relação à psicanálise no ambiente universitário, principalmente, na formação dos educadores, em que impera o discurso pedagógico. Essencialmente, dois aspectos estão implicados nesta polêmica: em primeiro lugar, a impossibilidade de predição e controle do objeto em torno do qual a teoria psicanalítica foi desenvolvida (o inconsciente); em segundo lugar, a problemática envolvida na questão da transmissão e do ensino da psicanálise, em suma, a negação dos efeitos da transmissão pelo discurso da universidade.

Imersa no cenário mundial que acompanha as produções da comunidade científica, diante das diferentes culturas visitadas, das lutas e conquistas que caracterizaram os últimos períodos históricos, a transmissão da psicanálise, mesmo pretendendo manter-se fiel a Freud, vem apresentando várias nuances desde seus primórdios. O terceiro capítulo apresenta um panorama dos modelos de mestria no contexto da psicanálise, partindo da delimitação do estilo de Freud. A partir dele, é possível fundamentar a implicação da relação estabelecida com o conhecimento a ser transmitido, produzindo estilos particulares naqueles que se revestem de responsabilidade pela transmissão. Assim, o que neste trabalho é designado por estilo, representa, em última instância, o resultado do desejo investido no conhecimento a ser transmitido, ou ainda, a relação do sujeito com o conhecimento.

O quarto capítulo dedica-se ao trajeto percorrido pela conexão psicanálise-educação, desde a utópica profilaxia das neuroses por meio de "pedagogia-psicanalítica", até a compreensão da proposta freudiana de uma educação para a realidade. Nesse capítulo, enfatiza-se a especificidade e a fertilidade da transmissão da psicanálise na formação de educadores que, uma vez atravessados pelo saber psicanalítico, podem conceber a noção de estilo, de singularidade na relação com o conhecimento. Portanto, a transmissão psicanalítica a educadores possibilita a implicação com o ato de educar, o reconhecimento do sujeito (do inconsciente), o questionamento sobre si e sobre os ideais que animam seu exercício. 


\title{
CAPÍTULO I
}

\section{DO RACIONALISMO AO CIENTIFICISMO: O DISCURSO PEDAGÓGICO}

\author{
"Disciplina fundadora amplamente 'teórica', \\ a História da Educação perdeu grande parte \\ do seu sentido no momento em que a \\ Pedagogia passou a definir-se numa \\ perspectiva 'aplicada', com base nos critérios \\ 'cientificos' da psicologia experimental e da \\ sociologia positivista". (Apresentação de \\ António Nóvoa para "História da Pedagogia" \\ de Franco Cambi, 1999)
}

Enfatiza-se uma mudança radical na forma de compreender a pedagogia, atrelada às mudanças percebidas na educação. Até o início do século $\mathrm{XX}$, a pedagogia era caracterizada por um conjunto de teorias que, pretensamente, se deduziam dos sistemas filosóficos. Isto é, de cada teoria se extraía uma determinada concepção de educação que, por sua vez, gerava modos distintos de operar práticas pedagógicas. Segundo Cambi (1999), a forma tradicional de se pensar os problemas educativos, predominante ou exclusivamente filosófico, reduzia-se a um saber pragmático e normativo.

A partir da segunda metade do século $X X$, a pedagogia tornou-se "outra coisa":

... redescrita em termos empíricos, articulou-se sobre várias ciências (...) predispôs um saber tecnicamente mais eficaz, pensando sobre a experiência e pela experiência, para guiá-la, para modificá-la, para planificá-la. Entre o empirismo (ciência empírica) e tecnologia, se dispôs a nova identidade da pedagogia... (Cambi, 1999, p. 599)

Cambi afirma que, hoje, os problemas educativos devem ser pensados a partir dos saberes empíricos que compõem as ciências da 
educação. Isso significa submetê-los a processos de análise e de intervenção "que permitam soluções verificáveis, inspiradas numa lógica da experimentação e do controle científico" (idem, p. 598, grifos nossos).

Múltiplos modelos articularam o estatuto lógico subjacente ao discurso da pedagogia. Dentre os maiores, o modelo analítico o vê organizado em torno da lógica científica, ao critério da explicação e verificação, sobretudo representado pelo pensamento pedagógico norteamericano (neoempirismo lógico). O modelo estruturalista, principalmente de inspiração no racionalismo crítico de $\mathrm{Popper}^{4}$, empenhado numa metateoria que evidenciasse os aspectos científicos das pedagogias e dos seus discursos. O modelo dialético (partindo de Marx e de Gramsci, por exemplo) reconduzindo a pedagogia para o terreno da ideologia, propondo um saber pedagógico de base científica, por sua vez, corrigido pela consciência política.

Uma ciência positivista, empirista, social, política, natural... Oscilante e, até certo ponto, confusa. Em meio a uma longa (e ainda atual) busca por uma identidade ${ }^{5}$, a pedagogia ora é definida como a ciência da educação (aparente consenso entre seus representantes), ora como uma das ciências da educação. Libânio e Pimenta a definem como "ciência da prática social da educação" (2002a, p. 35), buscando delimitar, ainda mais, sua significação epistemológica.

Ao longo do texto que ora se apresenta, transitam idéias de pedagogos adeptos dos três modelos. Mesmo assim, pode-se dizer, em linhas gerais, que à pedagogia tem sido atribuída a responsabilidade pela investigação das práticas educativas, de forma a organizar a concretização dos meios e processos educativos de uma sociedade. Tal responsabilidade implica, como se afirma, na investigação dos conhecimentos e saberes que pretendam ser aplicáveis à educação e, propondo-se estudar o fenômeno educativo em sua globalidade, promove a inter-relação dos saberes científicos, ao integrar os enfoques parciais das ciências da educação, "em função de uma aproximação global e intencionalmente dirigida aos

\footnotetext{
${ }^{4}$ Ver nota na página 60.

5 Uma identidade in fieri, como define Cambi (1999, p. 642) e como é possível verificar em "pedagogia e pedagogos: caminhos e perspectivas", organizado por Selma Garrido Pimenta (2002).
} 
problemas educativos" (idem, p. 37).

Investigadora da prática educativa e integradora dos diversos enfoques das ciências da educação, a pedagogia se constitui, segundo Libânio, "na teoria e prática da formação humana" (in Pimenta, 2002, p. 61), fundamentando-se no conceito de educação como "prática social que busca realizar nos sujeitos humanos as características de humanização plena" (idem, p. 66). Isto é, se o objetivo final da educação é a humanização plena dos sujeitos, segundo o autor, cabe à pedagogia formular a teoria e a prática que conduzirão a educação ao alcance de seu objetivo.

Tamanha responsabilidade ainda é ampliada pelo imperativo de que a pedagogia sustente a exigência de uma cultura geral para todos. Para tanto, Libânio afirma a necessidade de

... conhecer e compreender motivações, interesses, necessidades de alunos diferentes entre si, capacidade de comunicação com o mundo do outro, sensibilidade para situar a relação docente no contexto físico, social e cultural do aluno. (Ibid., p. 89)

A Pedagogia contemporânea, portanto

Não pode mais desconhecer o fato de que as escolas precisam responder pela ajuda ao fortalecimento das subjetividades dos alunos, ao lado de desenvolver também o sentimento de pertencimento à humanidade, à coletividade, implicando valores de compartilhamento e solidariedade. (Ibid., p. 89)

Como "tecnologia organizadora da prática docente" (Franco, in Pimenta, 2002a, p. 125), investigando os conhecimentos e saberes que se organizam historicamente, a pedagogia fundamenta "as bases dos saberes, diretrizes e orientações à praxis educativa" (idem, p. 122).

Frente às freqüentes situações imprevistas na prática educativa, segundo Franco, o fazer educativo deve ser investigativo, oportunizando a expressão do novo, para que ele seja analisado a partir de uma ação coletiva, dialógica e emancipatória entre os sujeitos da prática. O sujeito da prática, como investigador da prática, utilizará "procedimentos que possam desencadear ações formadoras e incentivadoras dessa emancipação, produzindo a transformação democrática da realidade" (ibid., p. 124). Portanto, (e para tanto), conclui a autora, "o fazer educacional há que ser 
científico" (ibid., p. 124, grifo nosso).

Comum a qualquer sociedade humana, a educação em saberes precedentes nem sempre dependeu (e há muitas sociedades que continuam não dependentes) de um discurso pedagógico que sistematize sua prática. Carvalho (2001) supõe que essa necessidade surja de sociedades onde o grau de especialização tenha sido intensificado, onde há diversidade de valores e metas educacionais, além de uma complexidade das instituições. Assim, tendo a educação como centro de seus debates, questionam-se sobre a constituição dos conhecimentos e das aprendizagens, sobre sua transmissão e objetivos.

Sejam quais forem os fatores, hoje, pode-se perceber que a pedagogia, como ciência da educação, observa, analisa, avalia, valida e "autoriza" para a educação (ou não) os diversos saberes, com vistas a garantir a cientificidade das pretensas contribuições à prática educativa, em boa parte das sociedades ocidentais: "através do filtro científico-técnico [a pedagogia] vive agora a sua estreita relação com a prática. E é com esse modelo de pedagogia que a pesquisa científica atual deve trabalhar, assumindo-o como guia" (Cambi, 1999, p. 599).

O "especialista em ciências da educação" ou o "operador educativo mais pedagogo" é, para Cambi, quem melhor pode "colher e julgar o background de teorias, práxis, posições da educação, sua espessura temporal (social, teórica, científica e prática) e operar assim um controle mais autêntico e mais capilar do próprio saber e agir" (idem, p. 19). Em suma, o pedagogo é considerado o especialista que analisa e arbitra sobre $o$ conjunto das ciências da educação e demais pretensas contribuições ao campo educativo.

Alguns discursos paralelos fortalecem esse propósito, dentre eles: o veloz desenvolvimento científico-tecnológico; a globalização da economia que dita modelos ao mercado de trabalho e, como uma das supostas conseqüências desse panorama, a necessidade de se desenvolver, nos alunos, a qualidade de pensar, manifesta no lema aprender a aprender. Um último e, talvez, mais expressivo discurso, sobre a qualidade do educador que, nesse contexto, possa fazer frente à prática educativa idealizada pela pedagogia: o professor reflexivo. 


\section{O contexto: a assim chamada "sociedade do conhecimento"}

Percebe-se, claramente, uma descrição enfatizada das mudanças ocorridas no interior da pedagogia, que não se limitam ao desenvolvimento do conjunto das ciências da educação, mas que (também por meio destas) pretendem acompanhar e abranger a dimensão política e econômica de um mundo conhecido por uma suposta "globalização". Acredita-se, portanto, que através de um esclarecimento, as práticas educativas poderão atender, com maior amplitude e complexidade, às exigências da sociedade globalizada.

Os pedagogos identificam as exigências provenientes desse mundo contemporâneo, as quais recaem sobre os educadores, a saber: novos objetivos, novas habilidades cognitivas, mais capacidade de pensamento abstrato e flexibilidade de raciocínio, capacidade de percepção de mudanças.

Para tanto, repõe-se a necessidade de formação geral e profissional implicando o repensar dos processos de aprendizagem e das formas do aprender a aprender, a familiarização com os meios de comunicação e o domínio da linguagem informacional, o desenvolvimento de competências comunicativas e capacidades criativas para análise de situações novas e cambiantes. (Libânio, 2002a, p. 94)

No entanto, nessa proposta, a educação parece ter tomado sentidos diferentes daqueles a partir dos quais foi estabelecida. Assentada no paradigma de que qualidade em educação significa preparar os indivíduos para o enfrentamento da competitividade internacional, a escola passa a ser pensada como uma empresa, o aluno um cliente, o conhecimento um produto comercial, como manifesta nesta percepção: "A última observação é que a evolução tecnológica e econômica levou a um novo relacionamento entre a escola e seus 'clientes" (Houot, in Avanzini, 1999, p. 150).

Do texto de Houot se extrai uma apreciação aparentemente otimista, por isso muito questionável, dessa nova realidade:

Durante longo tempo, principalmente na França, a escola e a empresa observavam-se de modo crítico; mas o sucesso das novas tecnologias e o da empresa, desde os anos 80, instalou o modelo da empresa como uma referência que tende a impor-se em toda parte, mesmo nas escolas. 
O autor ainda afirma: "o ambiente da empresa estava, sem dúvida, mais bem preparado" (idem, p. 151). Nesse trecho, Houot se refere à absorção das novas tecnologias. Mesmo assim, poderia ser questionado no seguinte sentido: o ambiente empresarial estaria melhor preparado, ou, como instrumento de um sistema capitalista, estaria pronto para dominar todos os segmentos da sociedade, principalmente aquele que já se encontrava a deriva diante da perda de seus fundamentos? Essa discussão será retomada no final deste capítulo.

Atendendo às novas exigências do mundo econômico, a um público diferente, procurando fazer frente à suposta concorrência da larga difusão dos meios de acesso ao "saber" e à informação, atendendo a expectativas sociais supostamente mais importantes, a escola se moderniza à imagem da empresa. Dentre tantos sinais de "modernização" da escola, a linguagem empresarial é incorporada ao discurso pedagógico. Alguns exemplos ilustram essa absorção: "além dos conhecimentos técnicos sobre a maneira de pôr em sinergia elementos e componentes (...) o segundo pólo de conhecimentos é relativo à gestão de grupos (...)" (Lamy, in Perrenout et alii, 2003, p. 43).

Em oposição, e em consonância com as idéias contidas nesta tese, Duarte (2001) relaciona cinco ilusões da chamada sociedade do conhecimento: primeira, que o acesso ao conhecimento foi amplamente democratizado; segunda, a capacidade de mobilizar conhecimentos é mais importante do que a aquisição de conhecimentos teóricos; terceira, o conhecimento válido é aquele proveniente dos contratos culturais (intercontinentais); quarta, os conhecimentos todos têm o mesmo valor; quinta, o surgimento de apelos românticos, irreais e descontextualizados ao cultivo do respeito às diferenças culturais.

No discurso dos que se percebem em conformidade com o contexto mundial, em geral os "informados", nota-se uma falta de diferenciação entre a noção de conhecimento e de informação. Uma questão que merece uma análise mais abrangente do que os limites deste texto. 


\title{
Tecnologias e descobertas científicas a serviço de uma "educação adequada"
}

\begin{abstract}
Como ser coerente com a realidade do aprendiz, como reconhecer nele um ser em devir, a caminho? Como lhe revelar seus recursos, seu potencial? Como construir o ato de ensinar a partir de um melhor conhecimento do ato de aprender? Como desvendar a lógica das etapas no decorrer das quais o professor é mediador? Quais as raízes e os mecanismos biológicos da aprendizagem, da linguagem, da percepção, da memória, da atenção? O que é inteligência hoje? Qual é a melhor progressão, o melhor ritmo para o organismo-que-aprende? Como dosar a parte do modelo e da autonomia em relação ao modelo? Como suscitar e manter a vontade de aprender? Qual é a natureza, o estatuto e o papel do saber? Como suscitar a alegria e o orgulho de conhecer? Como responsabilizar quem aprende?... (Trocmé-Fabre, in Avanzini, 1999, p. 59)
\end{abstract}

Numa cerimônia católica realizada nas proximidades do dia do professor, o padre cede a palavra da homilia ${ }^{6}$ a uma professora da rede pública de ensino. Muito orgulhosa pela oportunidade de falar a um público numeroso, muito maior do que sua sala de aula, a professora lembra da figura bíblica de Jesus Cristo, como educador de seus apóstolos e, com forte entusiasmo, lança uma curiosa observação: "Se sem nenhum recurso Ele conseguiu tamanho êxito, o que não podemos fazer diante da realidade atual, como, por exemplo, o fato de termos computador, televisão e uma antena parabólica em cada escola?" A professora parecia não ter dúvidas que, dispondo de tecnologias, ensinaria melhor que Jesus Cristo.

$\mathrm{Na}$ ocasião, não foi levantada a possibilidade de as novas soluções tecnológicas permitirem dispensar a própria professora no processo de formação do aluno, que: uma vez autônomo e motivado, frente ao caráter lúdico do computador, e, livre do julgamento do adulto (meio "emocionalmente neutro"), segundo Houot (1999), acha-se mais à vontade para aprender.

Postulando uma "criança autônoma", o educador renuncia à sua função. Nessa perspectiva, pretensamente superior à capacidade da professora e, conseqüentemente, de Jesus Cristo, se poderia supor, então, que o padre deverá, em breve, dispor de um computador para realizar a

\footnotetext{
6 "Pregação em estilo familiar e quase coloquial sobre o Evangelho" (Ferreira, 1999, p. 1059)
} 
homilia no dia do extinto professor.

As máquinas tomaram um espaço significativo nos processos ensinoaprendizagem. A calculadora, a TV, o vídeo e, especialmente, o computador não são mais considerados suportes e passaram a receber o status de protagonistas em várias práticas educativas. Estas, mais impessoais, mais controláveis, mais microestruturadas, mais capazes de autocorreção, estão cada vez mais semelhantes ou próximas do "brilho e da glória" das experiências científicas, o que permite a crença numa pretensa programação didática mais eficaz e compreensiva.

\footnotetext{
As diversas máquinas para ensinar, segundo Skinner, são pedagogicamente positivas porque permitem a autocorreção, porque seguem o ritmo natural da aprendizagem, porque têm uma seqüência coerente. (Cambi, 1999, p. 616)

Outras inovações técnicas realizadas durante o século XX possibilitam ampliar o leque das soluções para individualizar o ensino, desenvolver novas formas de tutoramento e para vencer, de certa forma, as restrições de tempo. (Houot, in Avanzini, 1999, p. 152)
}

Hipoteticamente, as descobertas científicas (e as tecnologias decorrentes) guardam as respostas a tantos "como(s)" apresentados no início deste capítulo. Não apenas fornecendo um receituário dos meios (fórmulas, métodos, etc), mas, principalmente, sugerindo proporcionar um conhecimento mais do que abrangente, quase absoluto, capaz de prevenir os erros e tornar mais (cientificamente) adequado o propósito que a pedagogia vislumbra na educação.

Em meio ao grande volume de novidades científicas, Trocmé-Fabre (1999) destaca as ciências cognitivas ${ }^{7}$ como o ponto de convergência de muitas disciplinas e de recursos que evidenciam os conceitos de aprendizagem e memória como de acesso aos agentes da educação e ao público em geral, portanto, não mais restrito aos laboratórios.

Em 1950, com Karl Lashley, anunciadas como movimento de oposição ao behaviorismo, as ciências cognitivas se propunham estudar os mecanismos cerebrais implicados no comportamento. Na década de 70 , do século passado, tentaram fazer revelações em torno do (antigo) problema

${ }^{7}$ Esse tema retorna na página 79 
epistemológico sobre o conhecimento, através da informática e da eletrônica, já que, de acordo com o postulado de um de seus principais representantes, John von Neumann, "o cérebro humano é uma máquina lógica (...), cujas funções lógicas podem ser calculadas por redes de unidades simples (os neurônios)" (apud Trocmé-Fabre, 1999, p. 68). As ciências cognitivas alimentam uma concepção pedagógica dedicada a uma visão científica dos problemas da aprendizagem e da instrução, procurando estabelecer, em última instância, uma instrução científica.

Jerome S. Bruner (1915, apud Cambi, 1999) concebe uma escola que esteja organizada segundo uma "teoria da instrução", a saber: que considere a "progressão da aprendizagem"; que esteja estruturada a partir do princípio de "reforço" (capaz de uma aprendizagem auto-corretiva); e, que estimule a "vontade de aprender", através do intercâmbio e da valorização da competência.

Cambi (1999) apresenta uma perspectiva que merece ser submetida a questionamentos. Segundo ele, a pedagogia cognitiva deslocou o eixo da pedagogia para os processos de aprendizagem, qualificando-a no sentido instrutivo, tornou a pedagogia escolar mais racionalizada e mais eficaz, adquirindo um papel crucial no âmbito das sociedades industriais marcadas pelo crescimento das informações e pela difusão das tecnologias.

Uma pedagogia mais racionalizada, sim. Mais eficaz?

É possível identificar vários problemas na apreciação feita por Cambi. Dentre eles, talvez o mais importante, a avaliação positiva dos resultados da educação atual. Essa discussão será contemplada em breve neste capítulo, por ora, outro discurso ilustrará o que pode ser chamado de cientificismo pedagógico: as ciências naturais.

Além do neocomportamentalismo de Skinner e do desenvolvimento do computer science, Hélène Trocmé-Fabre (1999) elege um estudo científico sobre o qual acredita que a educação deva encontrar apoio para inscrever-se na evolução: a descoberta do DNA. Uma realidade complexa a ser ensinada como referência do "livro da vida", pois implica num processo de complementaridade (cooperação), duplicação (multiplicação), estabilidade, ligações externas e trocas que ilustram o equilíbrio do eixo dar e receber. 
O DNA, segundo Trocmé-Fabre, comprova a diversidade dos seres vivos, portanto, cada ser vivo é considerado um ensino e uma aprendizagem: desde uma ameba, cada sujeito (como o da educação) é uma universidade. Com tais lições biológicas sobre a diversidade, a autora acredita que se torna possível compreender noções de cooperação, de autoorganização e, principalmente, reconhecer a impossibilidade da homogeneização, já que, "a célula toma decisões constantemente" (idem, p. 74). Em última instância, o processo de humanização, de civilidade, estaria "autorizado", porque apoiado nas ciências biológicas. Em outras palavras: se o trabalho das células está apoiado no eixo dar e receber, por que não estariam as relações humanas?

Diante desse "destacado recurso científico", Trocmé-Fabre lança uma questão aparentemente inquietante: "o sistema educativo reserva espaço suficiente a essa capacidade fundamental de nosso cérebro?" (ibid., p. 74). Responde: somente num espaço em que se privilegie a iniciativa, a abertura de espírito, a colaboração, a autonomia e o questionamento, abarcaria a capacidade cerebral. De natureza transdisciplinar, esse espaço deve integrar a especificidades da disciplina, da didática e do aprendiz que, segundo a autora, formam a base do ato educativo:

Um lugar de encontro e ressonância, em que o aluno pode ser convidado a desenvolver sua capacidade inata, ilimitada, de aprender. Um lugar onde pode "alojar" seu potencial, aprender a atualizá-lo, construir seu "como ser". Um lugar onde se trata verdadeiramente do oficio de aprender (ibid., p. 82).

Uma "engenharia da aprendizagem", na percepção da autora, que inclui uma teoria do funcionamento mental e que respeita uma "democracia cognitiva", pleiteia uma engenharia da didática e da formação.

Nota-se que a compreensão da organização mental está creditada, exclusivamente, nas pesquisas em neurobiologia e nas ciências cognitivas.

O homem é uma mistura inseparável de racional e emocional. Os cientistas abordam esse problema sob diversos ângulos, conforme a área de pesquisa. Hoje, a afetividade é reconhecida como motor dos processos cognitivos. O cérebro afetivo (ou sistema límbico) é fortemente conectado a outras regiões cerebrais, particularmente a nossos lobos frontais, indispensáveis a nossa reflexão, à elaboração de nossa identidade e a nossas capacidades de planificação (ibid., p. 79). 
Uma suposta "engenharia" também qualifica as competências de um formador de professores: "... engenharia de formação para conceber, conduzir, avaliar uma ação de formação; de sociologia das organizações, das teorias da mudança, dos grupos, da comunicação para intervir numa equipe" (Altet et alii, 2003, p. 74, grifos nossos).

Assim, uma engenharia de aprendizagem estaria capacitada a dar garantias para que os agentes da educação contribuam com o projeto de desenvolver no aluno o ofício de aprender.

\section{Desenvolvendo a capacidade de pensar ou o "aprender a aprender"}

Muito comum encontrar, atualmente, o seguinte argumento: do surgimento dos novos paradigmas da ciência, das inovações tecnológicas e comunicacionais decorre uma transformação na concepção de conhecimento, que impõe uma reavaliação na investigação sobre o ensino e a aprendizagem. Segundo Libânio (in Pimenta, 2002a), trata-se de ampliar a atenção sobre os processos cognitivos, convertidos na prática do professor ao ensinar a pensar, ou desenvolver a qualidade do pensar. Exigência, para - autor, que deve ocupar o centro da gestão escolar e do projeto pedagógico.

Conforme a percepção dos autores, um repertório de teorias decorrentes das ciências da Educação habilitaria uma prática pedagógica munida de estratégias intencionalmente planejadas e, portanto, capaz de desenvolver, estimular, aperfeiçoar, especialmente no âmbito da educação formal, a capacidade de pensar:

... [estratégias] que ajudem o aluno a utilizar de forma consciente, produtiva e racional o seu potencial de pensamento e que permitam torná-lo consciente das estratégias de aprendizagem a que recorre para construir e reconstruir os seus conceitos, atitudes e valores. (Santos, 1994, apud Libânio, op.cit.., p. 60)

Frente à evolução do mundo do trabalho e com vistas à 
adaptabilidade do estudante, pensa-se em intervir explicitamente nos processos de pensamento. Na prestigiada perspectiva cognitivista, isto significa que, antes de ensinar, acredita-se ser necessário desenvolver as capacidades de aprendizagem, a agilidade mental e a credibilidade na própria capacidade. Esse último atributo é adquirido na extinção do reforço que mantém a convicção do fracasso por determinado aluno.

Duarte (2001) situa a pedagogia do aprender a aprender juntamente com: as pedagogias das competências, a ênfase no construtivismo, a Escola Nova (escola ativa) e os estudos na linha do "professor reflexivo".

O autor destaca quatro posicionamentos valorativos no lema "aprender a aprender": primeiro, prioridade às aprendizagens que o aluno realiza por si mesmo, em detrimento da transmissão de conhecimentos e experiências pelo outro; segundo, maior importância à construção de conhecimentos, sua elaboração e descoberta, do que a aprendizagem dos saberes já constituídos; terceiro, são os interesses e necessidades da criança que devem conduzir sua atividade; quarto, a educação deve preparar os indivíduos para uma sociedade em constante e acelerado processo de mudança.

Em linhas gerais, na percepção de Duarte, o núcleo fundamental do lema "aprender a aprender" é formado por uma "concepção educacional voltada para a formação da capacidade adaptativa dos indivíduos" (2001, p. 38). O caráter adaptativo dessa pedagogia evidencia-se em alguns lemas, tal como "formar as competências necessárias à empregabilidade". Nesse prisma, os ideais pedagógicos estariam confundidos e fundidos aos ideais da sociedade capitalista contemporânea.

\section{A leitura cientificista do construtivismo}

Essa nova perspectiva na compreensão da aprendizagem, supostamente oposta à tradição escolar, orienta-se, segundo a declaração oficial [Parâmetros Curriculares Nacionais], pelos "enfoques cognitivos", que têm como marco de referência a teoria genética de Piaget e de outros teóricos do desenvolvimento que compõem o quadro da educação construtivista (Monteiro, 2000, p. 17). 
Seja em âmbito nacional, como nos Parâmetros Curriculares Nacionais, ou mundial, como no Relatório Jacques Delors (relatório da comissão internacional da UNESCO), as mudanças que redirecionaram o suposto enfoque tradicional na transmissão para o enfoque na aprendizagem convergem para um mesmo referencial teórico: o construtivismo.

Ensinar, hoje, para a maioria dos autores, deve consistir em conceber, encaixar e regular situações de aprendizagem seguindo os princípios pedagógicos ativos e construtivistas. Nessa perspectiva, as descrições das práticas educativas da, assim chamada, escola tradicional recebem um contorno caricaturado: autoritário, ultrapassado, baseado na frágil intuição dos antigos educadores.

Compreende-se que uma prática fiel aos princípios construtivistas deva aplicar a tese de que o conhecimento é fruto da ação do sujeito. Aliás, a expressão "o sujeito constrói seu próprio conhecimento" resultou no conceito "construtivista", como termo-chave da perspectiva piagetiana e ponto de convergência com as demais teorias psicogenéticas interacionistas e outras correntes associadas.

Por isso, o conceito de "escola ativa" que teve origem no início do século XX, com a Escola Nova, tomou um sentido atual (apesar de preservar suas características originais) e, principalmente, numa conotação científica de prática educativa.

Essa pretensa prática educativa científica estabelece novos papéis: 0 professor não é mais transmissor de informações, mas um "colaborador indispensável da classe"; a noção de aluno é substituída por sujeito psicológico, seja uma criança ou um adolescente.

Para que o dito autoritarismo seja evitado na educação de crianças e jovens, pensa-se ser imperioso apresentar razões e submetê-las a um juízo crítico baseado, num conhecimento científico, fundamentalmente "construtivista". Nesse ínterim, percebe-se, claramente, que o novo papel atribuído ao professor tem provocado prejuízos à sua legítima autoridade.

A "Pedagogia Ativa", como critério de fidelidade ao modelo construtivista, segundo Carvalho, é pouco clara: "O próprio Piaget alerta 
para o fato de que, em uma perspectiva construtivista, o conceito de 'ação' não deve ser compreendido no plano puramente físico ou material, mas inclui as 'ações mentais' ou 'operações'” (2002, p. 47). Sendo assim, desde que envolva o pensamento do aluno, uma aula expositiva pode ser considerada ativa.

De Rousseau até Froebel e Pestalozzi, é introduzida a idéia de que o objetivo central da educação seria desenvolver as capacidades psicológicas da criança, de acordo com o ritmo, as etapas e a natureza do desenvolvimento infantil. Esse ideal encontra em Piaget um apoio pretensamente inquestionável, já que provém de investigações empíricas e não mais numa "imprecisa intuição" de educadores ou numa perspectiva filosófica.

As ações educativas, veiculadas nas concepções construtivistas e conceitos oriundos de investigações e teorias psicológicas, são compreendidas e transformadas de maneira a conferir pretensas bases científicas. Assim, porque psicologicamente (portanto, cientificamente) embasados, o ensino e a nova "relação professor-aluno" são pretensamente mais adequados, mais eficazes e de maior respeito pelo aluno. ${ }^{8}$

José Sérgio de Carvalho (2001) estabelece várias críticas à apropriação dos conceitos construtivistas pelo discurso pedagógico, dentre elas, talvez a mais central fosse de que, em abstração do contexto empírico e discursivo em que foram, a princípio, elaborados os resultados de pesquisas psicogenéticas, os conceitos e as concepções sobre 0 desenvolvimento psicológico são transpostos para o contexto escolar, deduzindo daí conseqüências, implicações e um pretenso saber disponível para aplicações práticas nesse campo.

\footnotetext{
No entanto, os resultados dessas pesquisas não constituem um discurso pedagógico no sentido estrito, posto que não têm na instituição escolar e na aprendizagem que nela se realiza nem seu ponto de partida, nem seu destino primordial. Não visam, portanto, a constituir-se em discurso esclarecedor ou orientador das práticas educativas escolares, mas apenas buscam compreender certos processos psicológicos presentes na criança e pretensamente subjacentes ao seu processo de desenvolvimento e aprendizado, mesmo que ele ocorra à margem das instituições escolares (Carvalho, 2001, p. 43).
}

\footnotetext{
${ }^{8}$ A autora da presente pesquisa tratou amplamente desse tema em dissertação de mestrado A transferência e a ação educativa (2000).
} 
O autor também lança um questionamento sobre as incursões de Piaget no contexto escolar. Segundo Carvalho, mesmo reconhecido como autor cioso da observação empírica em psicologia, Piaget descreve práticas escolares que não partiram desse tipo de observação, mas apenas das vagas impressões que o cientista tinha de uma sala de aula. Dessa forma, as referências ao contexto escolar desconsideram o fato de que cada sala de aula possua uma dinâmica própria e peculiar.

O discurso pedagógico construtivista, apoiado num espírito científico, tem cometido uma série de reducionismos: "Propondo procedimentos e orientações que ignoram as particularidades do contexto escolar e os compromissos educacionais com certas tradições públicas" (idem, p. 68).

A partir de uma relação particular com o conhecimento, o professor educa no intuito de preservar certas tradições culturais. $O$ desenvolvimento e a realização dos sujeitos são conseqüências desse seu propósito.

\title{
O conceito de "professor reflexivo" na formação de educadores
}

\begin{abstract}
Dada a natureza do trabalho docente, que é ensinar como contribuição ao processo de humanização dos alunos historicamente situados, esperase dos processos de formação que desenvolvam os conhecimentos e as habilidades, as competências, atitudes e valores que possibilitem aos professores irem construindo seus saberes fazeres docentes a partir das necessidades e desafios que o ensino como prática social lhes coloca no cotidiano. (Libânio; Pimenta, 2002a, p. 44)
\end{abstract}

Um panorama mundial complexo, descrito por autores dos mais variados campos do saber como: de velozes mudanças, grandes desafios, intensa competitividade, descobertas científicas, acesso ilimitado a informações, valorização do conhecimento, exige sujeitos com know-how nos diversos setores da sociedade, especialmente capazes de operar a "máquina industrial". Uma sociedade supostamente movida por muito conhecimento demanda sujeitos competentes, criativos, dinâmicos, capazes de conduzir um trabalho em grupo, além de uma infinidade de outras características associadas à empregabilidade. Os movimentos no campo 
educativo somam-se a esse panorama: a nova "Pedagogia Científica"; o enfoque no processo de aprendizagem; a ruptura com uma educação tradicional pautada em algumas vertentes filosóficas.

A "transformação dos saberes" e as mudanças histórico-sociais, numa sociedade descrita por Cambi como mais dinâmica e mais aberta "... reclama a formação de homens sensivelmente novos em relação ao passado; homens-técnicos e homens-abertos capazes de fazer frente às inovações sociais, culturais e técnicas" (1999, p. 595).

Talvez se possa acrescentar certa tendência do discurso pedagógico em aderir rapidamente às novidades, uma tendência ("bem brasileira") aos modismos. Como descreve Libânio (in Pimenta, 2002b), uma tendência manifesta em um rápido abandono de linhas de pesquisa, em favor de outras consideradas mais novas, por isso, pretensamente mais avançadas. Um permanente abandono dos paradigmas clássicos do conhecimento.

Dessa forma, a definição da imagem do saber pedagógico mudou, configurando-se como saber hipercomplexo "a ser submetido a uma coordenação reflexiva e capaz de desenvolver também uma radical autoreflexão" (idem, p. 598).

Um saber hipercomplexo, a serviço da preparação desses novos homens, implica numa nova e inquestionável competência dos professores. Conseqüentemente, desde 1990 e a partir dos pressupostos do norteamericano $D$. Shön, a formação de professores tem recebido forte influência do conceito de professor reflexivo, proveniente de grupos de pesquisadores em diferentes países.

Valendo-se do conceito de experiência compreendida (reflexão na experiência), da filosofia de John Dewey ${ }^{9}$, Shön trabalhou com reformas curriculares nos cursos de formação profissional. Criticou o clássico modelo didático em que primeiro se apresenta a ciência ao aluno, depois sua aplicação e o estágio, propondo uma epistemologia da prática:

\footnotetext{
${ }^{9}$ John Dewey (1859-1952), professor norte-americano de renome mundial, cuja ação pedagógica se deve à renovação dos métodos de ensino nos Estados Unidos. Essencialmente, considerava a escola como o baricentro de toda a vida social e a mola de seu desenvolvimento, ou seja, colocava como central a função política da pedagogia. Em 1896, junto à Universidade de Chicago, Dewey fundou
} 
... valorização da prática profissional como momento de construção de conhecimento $^{10}$, através da reflexão, análise e problematização desta, e o reconhecimento do conhecimento tácito, presente nas soluções que os profissionais encontram em ato. (Pimenta, 2002b, p. 19, grifo nosso)

Desenvolvendo a capacidade de refletir, de acordo com essa concepção, os professores serão capazes de responder a situações novas. $\mathrm{E}$, diante de situações que superem o repertório constituído, o professor reflexivo, também um professor pesquisador da prática, analisa, contextualiza, estabelece possíveis explicações sobre a gênese, problematiza, dialoga com outras perspectivas, apropria-se de teorias sobre o problema e, dessa forma, mantem-se investigando.

Claramente tributária do conceito, Pimenta (2002b) expõe algumas críticas à apropriação generalizada da perspectiva da reflexão, dentre elas, o risco da individualização do professor, isto é, um descompasso com um contexto mais amplo, chamado de político-epistemológico. A pesquisa organizada e publicada pela autora, Professor reflexivo no Brasil: gênese e crítica de um conceito (2002b), se debruça sobre as diversas modalidades de reflexão, como conhecimento do conhecimento, ou, ato de pensar sobre si mesmo; como reflexão sobre uma experiência concreta; reflexão dialética, como realidade dada/captada pela reflexão; reflexividade de cunho neoliberal (no âmbito do positivismo e do tecnicismo); reflexividade de cunho crítico (reconstrucionista social).

A potencialidade reflexiva do professor se define por sua capacidade de pensar sobre os próprios pensamentos e atos, sobre o contexto social e sobre as formas de intervenção (estratégias, intenções e representações). Fundamentalmente e, a fim de superar uma abordagem tecnicista do conceito de reflexividade, como metodologia de trabalho, afirma-se ser necessária uma teoria crítica que permita aos professores "ver mais longe" (Libânio, in Pimenta, 2002b, p. 67).

Da mesma forma que na pedagogia do aprender a aprender, desenvolvido no aluno, o conceito de professor reflexivo aponta para a necessidade de potencializar a aprendizagem do professor: "os mesmos

uma "escola-laboratório", uma verdadeira escola experimental. Trbutário do puericentro pedagógico que tem origem em Rousseau (Lello, 1966; Cambi, 1999).

${ }^{10}$ Novamente o conceito construtivista no discurso pedagógico. 
processos e resultados que devêssemos esperar da formação geral dos alunos das escolas regulares deveriam ser conteúdos da formação de professores" (idem, p. 73). Em suma, o lema "refletir sobre a prática" vem na tentativa de promover o professor a pesquisador e, assim, pretende-se alcançar o êxito da educação escolar. Em substituição ao tecnicismodidático, a reflexão sobre a prática impediria a aplicação cega das estratégias e dos recursos tecnológicos que, agora, se ajustam à realidade dos acontecimentos.

Entretanto, a elucidação psicanalítica na educação afasta a idéia de um racionalismo que reflete e deduz a educação de uma criança. Aponta, pelo contrário, que o que faz ato na educação não se relaciona com o acúmulo de saber, mas repousa naquilo que se transmite sem saber, transmite-se, portanto, o não sabido. A transmissão da impossibilidade de se saber sobre o desejo é o que constitui o faire semblant do adulto.

Numa publicação francesa de 1987, é recuperada uma excêntrica experiência pedagógica do início do século XIX, que, apesar de não representar algum modelo de prática pedagógica, suspende qualquer certeza sobre uma imperiosa racionalidade no ato de educar. Jacques Rancière relata a história de Joseph Jacotot, revolucionário na França de 1789 que, depois de ter desempenhado altos cargos públicos e ter lecionado Análise, Ideologia e Línguas Puras e Transcendentes e Direito, em 1818, é exilado nos Países Baixos, onde recebe permissão de lecionar.

A peculiaridade da história de Jacotot é que, tendo assumido o posto de professor, um bom número de alunos dispostos a beneficiarem-se de suas lições ignoravam o francês, enquanto Jacotot, por sua vez, ignorava completamente $\mathrm{o}$ holandês. No entanto, procurando responder às expectativas, o professor decide recorrer, aleatoriamente, a algum texto publicado nos dois idiomas (Telêmaco), solicitou aos alunos que aprendessem amparados pela tradução francesa. Tratava-se de uma solução de improviso, cujo resultado superou as expectativas do próprio Jacotot. 
Ele estava esperando por terríveis barbarismos ou, mesmo, por uma impotência absoluta. Como, de fato, poderiam todos esses jovens, privados de explicações, compreender e resolver dificuldades de uma língua nova para eles? De toda forma, era preciso verificar até onde esse novo caminho, aberto por acaso, os havia conduzido e quais os resultados desse empirismo desesperado. Mas, qual não foi a sua surpresa quando descobriu que seus alunos, abandonados a si mesmos, se haviam saído tão bem dessa difícil situação quanto o fariam muitos franceses! Não seria, pois preciso mais do que querer, para poder? Todos os homens seriam, pois, virtualmente capazes de compreender o que outros haviam feito e compreendido? (Félix e Victor Ratier, apud Rancière, 2004, p. 18-19)

Numa lógica absolutamente inversa aos paradigmas do "professor reflexivo", do "aprender a aprender", a experiência de Jacotot evidencia certa cegueira da racionalidade pedagógica, da necessidade de explicações: "Ninguém nunca sabe, de fato, o que compreendeu. $E$, para que compreenda, é preciso que alguém tenha dado uma explicação, que a palavra do mestre tenha rompido o mutismo da matéria ensinada" (Rancière, 2004, p. 20-21).

Considerando-a como "mito da pedagogia", Rancière enfatiza a proliferação e o aperfeiçoamento da explicação para melhor ensinar e melhor aprender. Apesar de, frisa ainda o autor, não encontrar manifestações de que a compreensão tenha sido efetivamente aperfeiçoada. Em última instância, os métodos racionais da pedagogia servem para "endireitar" o acaso, pelo caminho da razão. No entanto, com Jacotot, os alunos aprenderam sem mestre explicador, o que não significa a ausência do mestre. Jacotot havia sido mestre quando "retirava" sua "ciência", ou, sua inteligência para deixar a inteligência dos alunos entregues àquela do livro.

\footnotetext{
A criança que repete as palavras aprendidas e o estudante flamengo "perdido" em seu Telêmaco não se guiam pelo acaso. Todo o seu esforço, toda a sua exploração é tencionada pelo seguinte: uma palavra humana lhes foi dirigida, a qual querem reconhecer e à qual querem responder - não na qualidade de alunos, ou de sábios, mas na condição de homens (...) (idem, p. 29).
}

No ato de ensinar e de aprender, segundo Rancière, há duas inteligências e duas vontades, no entanto, o que sustenta a ação educativa não se relaciona com ligar uma inteligência a outra, mas uma sujeição de vontade a vontade: "o aluno estava ligado a uma vontade, a de Jacotot, e a 
uma inteligência, a do livro, inteiramente distintas" (idem, p. 32). Assim, Jacotot poderia ensinar inclusive o que ignorava. ${ }^{11}$

Vivendo um contexto político (pouco diferente do atual) em que a instrução era palavra de ordem central, em que o desenvolvimento de práticas de instrução tinha como objetivo oferecer maior acesso ao homem do povo, fazendo com que o conhecimento estivesse adaptado ao nível de inteligências limitadas (uma racionalização das formas de aprendizagem, tornando-as mais acessíveis aos desiguais), Jacotot expõe um paradoxo: pretendendo reduzir a desigualdade social, a escola e a sociedade não cessam de reproduzí-la. Em outras palavras, ao estabelecer a igualdade como objetivo, a desigualdade e a incapacidade são colocadas de antemão, e se confirmam, uma vez que a redução das mesmas torna-se o próprio significado de educar. Em síntese, o que a escola pretende reduzir, a desigualdade, não cessa de reproduzir e eternizar. Dessa forma, em $O$ Mestre Ignorante (2004) Rancière valoriza, na experiência de Jacotot, a idéia de que a igualdade é fundamental e ausente, assim como, é dependente de que sejam permanentemente inventadas formas de sua verificação.

\section{Desenvolvimento de capacidades e inserção profissional: finalidades da educação?}

Diante do exposto até aqui, uma síntese do propósito da educação, compreendido a partir do discurso pedagógico atual, pode ser configurada em duas idéias principais: os alunos precisam aprender a aprender e os professores precisam aprender a refletir. Daí, uma dúvida é desencadeada: tais competências não existiam ao longo da história da ação educativa? "Não é bem assim", talvez respondesse um pedagogo. Provavelmente concluiria que, "hoje, o aprender e o refletir recebe suporte científico, portanto, é melhor, porque mais eficaz e mais fiel à realidade psicológica dos

\footnotetext{
${ }^{11}$ Apesar de não se fundamentar na psicanálise para a discussão que faz a partir da experiência de Jacotot, Rancière aproxima-se, até certo ponto, de algumas noções psicanalíticas sobre o ato de educar, especialmente o conceito de mestre não todo e sobre o desejo de saber.
} 
sujeitos e à realidade social-política-econômica da sociedade mundial".

Deduz-se que no dito ensino tradicional havia uma precariedade de conhecimentos científicos aplicados à prática educativa, causando prejuízos à aprendizagem. Hoje, com as mudanças que culminaram na pedagogia científica, a prática educativa se pretende mais eficaz.

Ao longo do século $X X$, destacou-se uma preocupação em combater - fracasso escolar, por meio da generalização de uma estratégia que permitisse o sucesso de todos. Para além desse propósito, no cotidiano escolar, questões preocupantes continuam, cada vez mais, a assombrar a educação em proporções internacionais. Entre as mais evidentes: a indisciplina, o baixo nível de conhecimento dos alunos das últimas etapas de escolarização e a deficiência da população universitária.

Mougniotte apresenta um diagnóstico claro e realista das condições atuais da educação, relacionando a abundância de pesquisas em torno de metodologias e a contraditória dificuldade de se instruir:

Trata-se de um paradoxo chocante: nunca, sem dúvida, se inventaram tantos métodos, mas nunca se constatou tanto a dificuldade de conseguir a instrução dos alunos. A riqueza da investigação parece proporcional à precariedade dos resultados (in Avanzini, 1999, p. 123).

Provenientes dos mais diversos modelos e mesmo professando os atuais desafios educacionais que a sociedade impõe ao ensino, os autores proclamam em coro o objetivo da educação: a humanização das gerações sucessivas. Nesse ínterim, a pedagogia seria, para o conjunto de pedagogos, o paradigma do desenvolvimento da humanidade.

No entanto, o que se pôde concluir dos textos sobre a pedagogia atual, diz respeito a uma concepção de educação dispersa, desviante, que ao pretender controlar tudo, tem se arriscado a perder tudo. Cada vez mais distante de sua finalidade, vê-se sintetizada em problemáticas opções: a formação com objetivo profissional em detrimento de uma educação (sentido amplo, onidirecional) e, conseqüentemente, a opção por uma cultura especializada, uma qualificação precisa, limitada a uma competência adquirida em vista do uso que dela será feito, no lugar de uma cultura geral. $\mathrm{Na}$ mesma linha, o objetivo de adaptação e a disseminação da idéia de 
evoluções inevitáveis, com automática aceitação, isenta de juízo pessoal.

Prevalece a concepção de ser humano como portador de um capital de capacidades sobre as quais é necessário investir, em detrimento de outra que 0 considera portador de um potencial polivalente, ou, fundamentalmente, um herdeiro de todo o conjunto de conhecimentos construídos pela civilização. Isto porque, junto às contestações da legitimidade das estruturas e dos poderes, a autoridade foi recusada, dando lugar a um ceticismo e, como efeito, uma crise moral dos adultos.

Uma crise que se originou num suposto engajamento ético no diálogo que, não mais movido pela diferença entre o adulto e a criança, agora, exprime justificativas cada vez mais explicáveis (Lajonquière, 2001). A absorção e apropriação dos saberes científicos disponibilizados pela psicologia do desenvolvimento, por exemplo, serviu aos pedagogos para justificarem essas opções.

Há que se reconhecer a diferença como condição necessária ao ato de educar. A diferença inicial, provavelmente, encontra-se na capacidade de apreensão das razões da ação educativa. Isto é, dado os limites que caracterizam os estudantes, tenta-se fazer com que estes acreditem que as coisas são deste ou daquele modo, em outras palavras, a razão da educação é em princípio de quem ensina. Uma perspectiva que destoa do apelo presente no discurso pedagógico à submissão das razões a um pretenso juízo crítico, pautado em critérios científicos, em suma, uma razão puramente racional.

A obsessão pelos métodos cientificamente fundamentados é apenas uma manifestação desse racionalismo cientificista. Uma prática educativa racional exclui a expressão dos infinitos estilos ${ }^{12}$ de educar.

Podemos, por exemplo, crer que a própria autonomia dos professores na escolha de um determinado modo de trabalho, desde que respeitados certos padrões morais, seja um valor mais importante no contexto educacional do que a eventual maior eficácia ou rapidez de uma certa forma de trabalho. (...) o êxito ou o fracasso de uma ação educativa não se mede apenas pela posse ou ausência de certas informações ou capacidades, mas necessariamente inclui a apreensão de valores $e$ procedimentos ligados ao seu conhecimento (Carvalho, 2001, p. 24).

\footnotetext{
${ }^{12}$ A ideia de estilo como expressão da singular relação do professor com o conhecimento será, mais
} adiante, foco de uma discussão sobre o ensino da Psicanálise. 
Se por um lado a educação vem ganhando volume e peso na sociedade global, a crise que também vem apresentando é atribuída ao desmoronamento das finalidades válidas anteriormente, das ideologias, dos valores que forneciam uma finalidade à sua ação (Avanzini, 1999). No lugar da rechaçada educação tradicional, vê-se um discurso pedagógico que se pretende original, racional e científico, no entanto, notoriamente hesitante e incerto.

As doutrinas, os métodos, as técnicas e a prática pedagógica visam o controle e a garantia do sucesso da ação. No entanto, como constata Lopes (2003), nada pode garantir o sucesso da educação. Tal impossibilidade traz mal-estar e gera ilusões. Lajonquière assinala o mesmo encadeamento: os modismos pedagógicos que se manifestam já há algum tempo têm se tornado cada vez mais velozes e, na intenção de tornar a escola mais "eficaz", "viva" e "significativa", paradoxalmente, impossibilitam um desdobramento fértil da crise escolar, portanto, "vão na contramão de uma reinstitucionalização da realidade da infância conhecida” (2001, p. 16).

O termo racionalismo é empregado no título deste capítulo na medida em que dá conformidade a um tipo específico de discurso sobre o conhecimento, identificado por uma:

doutrina segunda a qual nada existe que não tenha a sua razão de ser, de tal maneira que por direito, senão de fato, não há nada que não seja inteligivel. (...) todo conhecimento certo provém de princípios irrecusáveis, a priori, evidentes (...). Do ponto de vista da disciplina intelectual: fé na razão, na evidência e na demonstração (...) (Lalande, 1999, p. 910).

Em grande parte, o racionalismo traduz o sentido preponderante na delimitação da função da ciência, enquanto opõe-se a todas as formas de irracionalismos: misticismo, ocultismo, filosofia do sentimento, tradicionalismo.

Em Descartes, o método (como caminho, direção, avaliação e medida) existe para proporcionar maior alcance e fundamento à razão e, 
obedecendo ao pressuposto filosófico da unidade da razão, não há a possibilidade de que os procedimentos metodológicos variem diante de diferentes objetos. A unidade da razão significa a unidade do método, portanto, para esse filósofo, o conhecimento é sistemático. A sistematicidade do conhecimento exclui coisas, representações ou percepções que, mesmo existindo, não poderão se tornar objeto de conhecimento. Descartes reconhece, a partir da crença na veracidade divina, a existência de elementos que não se pode compreender ou conhecer completamente (Silva, 1996).

Espinosa, por sua vez, propõe um racionalismo absoluto, pautado na confiança na capacidade liberadora da razão, isto é, "afirma e demonstra que a totalidade do real é inteligível e pode ser inteiramente conhecida por nosso intelecto, não havendo lugar para mistérios, milagres e coisas ocultas" (Chauí, 1995, p. 34). Em busca de um conhecimento verdadeiro, no Tratado da Correção do Intelecto, Espinosa desenvolve um "caminho reflexivo", que consiste em fazer com que nosso intelecto conheça a si mesmo, como capacidade inata de conhecimento verdadeiro. Mais ainda, "O Tratado visa a oferecer à inteligência os recursos para chegar ao bem verdadeiro. Com isso, Espinosa articula internamente o desejo da felicidade, da liberdade e da verdade" (idem, p. 38).

Apesar de tão breve referência à designação do termo racionalismo e da reconhecida pluralidade do campo pedagógico descrita por $\mathrm{Cambi}^{13}$, o racionalismo se revela no discurso pedagógico refletido na pretensão de se evitar os erros, promover os acertos, através de controles e previsões científicas e da apreensão absoluta da realidade pela reflexão. Não só adere ao discurso capitalista do "mundo globalizado", como foi anteriormente tratado, mas também estabelece um ideal (como tal, irrealizável) de um desenvolvimento pleno das capacidades psicológicas das crianças e dos adolescentes, até mesmo do professor.

Um racionalismo pedagógico que se pretende científico, que busca

\footnotetext{
13 “Como saber complexo, que pode ser interpretado através de diversos paradigmas (ou modelos) teóricos, que deve confrontar-se de forma articulada e dialética (não linear e plural), como constituído de elementos diversos que só um metacontrole (...) permite fixar, reconhecer, e não caindo no erro de querer reduzir a complexidade / riqueza / variedade e pluralismo / conflitualidade da pedagogia" (1999, p. 637).
} 
avidamente pela instrumentalização do saber e pela tecnificação do ensino, parece muito mais próxima de um racionalismo radical, à moda espinosiana e distante de uma definição como a de Blum de que "a palavra pedagogia implica uma arte, preocupações finalistas e normativas que nada têm a ver com a investigação e a instituição de leis científicas" (in Lalande, 1999, p. 801), a pedagogia atual ultrapassa o racionalismo e beira o cientificismo, como uma

... idéia de que a ciência faz conhecer as coisas tais como elas são, resolve todos os problemas reais e é suficiente para satisfazer todas as necessidades legítimas da inteligência humana; (...) a idéia de que o espírito e os métodos científicos devem estender-se a todos os domínios da vida intelectual e moral, sem exceção (Lalande, 1999, p. 160).

No campo da pedagogia, como ciência que reflete e arbitra sobre as ciências da educação, há um movimento crescente de estudos sobre a prática do ensino e da aprendizagem, visando uma progressiva aproximação entre o discurso educacional e os discursos científicos, predominantemente demandados à psicologia do desenvolvimento e da aprendizagem (também da sociologia da educação) e, paralelamente, uma expectativa de conseqüente renovação das técnicas e procedimentos didáticos e pedagógicos.

\footnotetext{
Assim, um suposto avanço no campo teórico - decorrente da transposição dos modi-operandi das práticas e dos discursos científicosdeveria ter como conseqüência o desenvolvimento de procedimentos pedagógicos mais eficazes, já que seriam inspirados em teorias empiricamente testadas ou informações sistematicamente controladas (Carvalho, 2001, p. 28).
}

Reconstruindo-se em torno dos princípios psicológicos, na concepção de Cambi, a pedagogia deve integrar tais princípios, operar sobre eles e produzir sua "otimização": "... isto é, o uso mais amplo e completo possível em cada sujeito. A pedagogia tem, de fato, uma autonomia em relação à psicologia, enquanto disciplina operativa, que deve produzir efeitos na educação de determinados sujeitos" (1999, p. 610).

Tem-se a ilusão de que, amparados pelas ciências, os procedimentos didático-pedagógicos tragam garantias dos "efeitos" que se busca no aluno. A "Pedagogia Científica" mostra-se contrária à idéia de que o ensino possa 
ser uma invenção contínua, aleatória e arriscada, e que, por isso, como descreve Mougniotte (in Avanzini, 1999), só é possível tatear, tentar dispositivos desigualmente pertinentes e, ao final, avaliá-los de forma mais ou menos rigorosa. E, como invenção constante, a educação sempre será "problemática" (ou impossível, na concepção Psicanalítica) e a eficácia de um método nunca será garantida, tampouco universalmente bem-sucedida.

Valem algumas ressalvas: os efeitos, sobre os quais Cambi se refere anteriormente, são aqueles da ordem da previsibilidade e do controle estabelecidos pelos domínios da "Pedagogia Científica". A prática docente é compreendida como uma ação plenamente racional, programada e deliberada, resultante da capacidade de pensar.

Quando a subjetividade é mencionada pelos autores, recebe um caráter completamente consciente e racional. Por exemplo, Mireille Snoeckx assume que sua pesquisa em torno da formação de professores provém de uma história pessoal e parece concordar com a afirmação de Mireille Cifali: "É inútil narrar, ou descrever, se o portador da ação não assume sua subjetividade e nega o impacto do afeto na pesquisa. É nossa presença no texto, e não nossa ausência, que dá ao escrito seu interesse e perenidade" (in Altet et alii, 2003, p. 22). Entretanto, subverte a idéia de Cifali, no sentido em que não se contenta em assumir a interferência da própria subjetividade no trabalho, mas completa com uma esperança ou advertência: "uma subjetividade que pretendo controlada" (idem, p. 22, grifo nosso).

Gimeno Sacristán (1998), por sua vez, junto às necessidades, reconhece a interferência dos desejos e emoções no pensamento do sujeito, mas que, como acredita, também podem ser diretamente conhecidos pela reflexividade:

\footnotetext{
As ações apresentam-se aos sujeitos como inteligíveis à consciência, de modo que o que fazemos tem a ver com o que pensamos, e vice-versa. A reflexividade consiste, precisamente, nesse processo de tomar consciência da ação, de tornar inteligível a ação, pensar sobre o que se faz (Libâni, in Pimenta, 2002b, p. 69).
}

Em suma, quando o professor endereça uma demanda ao campo psi, sua expectativa é de receber orientações sobre métodos de ensino e aprendizagem e técnicas de motivação. Assim sendo, mantém-se afinado 
com o espírito da modernidade e surdo ao apelo do inconsciente (Bacha, 2002, p. 14).

Neste capítulo, propôs-se explicitar o que está sendo qualificado de racionalismo cientificista, característica do campo pedagógico e, assim, poder situar a contribuição psicanalítica, como reveladora dos elementos que ultrapassam (porque intangíveis) a dimensão racional no ato educativo.

Nesse sentido, o que se propõe não é, propriamente, da ordem do combate a um ideário, mas, dirigindo-se à comunidade educativa, buscando alcançar os olhos e ouvidos dos educadores (dentre eles, os que estão em formação), a presente pesquisa tem a intenção de trazer ao debate os impossíveis do exercício de educar.

Essa proposta implica, portanto, no esclarecimento de que a especificidade do ensino da psicanálise na formação de educadores, como legítima contribuição à educação, deve-se, essencialmente, a uma divergência entre seu discurso e o discurso pedagógico, dado a uma "cada vez mais central cientificização" deste último (Cambi, 1999, p. 600).

A psicanálise não oferece orientações para a prática educativa, certezas, tampouco garantias, por não comungar da idéia pedagógica de que tanto mais eficaz quanto mais ciência é acrescida à prática do educador. Em suma, para a psicanálise, educar não significa fazer ou aplicar ciência. Isto também porque, a psicanálise pensa a infância de outra forma, diferente daquela imaginada no discurso formado pelas injunções dos ideais pedagógicos.

Nesse ínterim, a psicanálise oferece condições para que a educação perceba os limites que se impõem às razões que a pretensa "Pedagogia Científica" se acha em condições de apresentar, quais sejam, sobre a ilustre ciência, a tecnologia, o mercado, os interesses da comunidade.

O que se percebe é que o discurso pedagógico, no interior da educação, não assume nada que seja da ordem do não saber. Por sua vez, retirando o véu que oculta os desejos, dos quais dependem as razões professadas pela pedagogia, a psicanálise revela à educação que estas 
supostas razões Ihe escapam. Logo, em tempos de valorização do pragmático, do lucrativo e do otimizado, a psicanálise mantém-se não pragmática, não diretiva, sem pretender controles ou utilidades, mas pretende resgatar um ensino em que o educador, sem a intenção de fazer render, sabe para que serve o que ensina (Bacha, 2002). Um resgate, todavia, que não representa um retorno às práticas educativas do passado, mas que, por meio da crítica e do questionamento, torna evidente o que ficou esquecido em relação ao eixo do trabalho educativo.

Cedendo espaço às formações imaginárias que caracterizam a atualidade, aquelas que alimentam a ilusão de um "mundo natural" cujo acesso dar-se-ia pelos objetos de consumo, pela adequação ao mercado, aos métodos psicopedagógicos, ao conhecimento científico e tecnológico, a educação assiste a falência de seu estatuto simbologênico.

É certo que vários elementos do campo educacional podem e têm sido objeto de investigação dos vários ramos da ciência, no entanto, em concordância com Carvalho (2001), a educação, seja ela familiar ou escolar, não constitui uma ciência nem um campo autônomo do conhecimento. Talvez se possa reconhecê-la no campo das artes.

Márcia Neder Bacha inicia seu texto recuperando a finalidade da Educação: "Na Antigüidade Grega, educar era a arte de iniciar o outro naquilo que o faria melhor, levando-o a cultivar-se e a cultivar em si a humanidade" (2002, p. 13). O que Bacha coloca sob a forma de questionamento, aqui talvez se possa exprimir como constatação: ao tornarse técnica de adaptar com pretensões à ciência, tendo o mercado como única ambição, a concepção de homem como obra a ser criada foi soterrada e a educação perdeu-se como arte de formar.

A apologia da objetividade científica que dá forma ao discurso pedagógico mantém a pesquisa e a formação dentro dos mesmos limites.

Mougniotte (1999) distingue dois tipos de pesquisa dos quais resultam os novos saberes em educação: a pesquisa em educação, a invenção e a aplicação de inovações que tendem a melhorar a prática; e a pesquisa sobre a educação, o conhecimento sobre o fenômeno educacional em si. Nesse segundo tipo é que a psicanálise, portanto também esta pesquisa, está situada. Não é sobre o como, mas, o porquê, o sentido, os mecanismos e 
estruturas de funcionamento que a educação põe em jogo, em suma, sua finalidade.

Todavia, a partir do discurso pedagógico, ao conjunto das pesquisas educacionais, tem-se exposto objeções em torno de suposta invalidade e inutilidade àquelas que não atendam um dos dois objetivos: credibilidade científica e utilidade prática (Mougniotte, 1999). A psicanálise, portanto, é duplamente objetada nesse campo.

O próximo capítulo tratará da questão da "credibilidade", a partir do debate em torno do estatuto epistemológico atribuídos à psicanálise. Em seguida, são apresentadas as questões sobre a transmissão e a "utilidade" da psicanálise na educação. 


\section{CAPÍTULO II}

\section{A PSICANÁLISE FRENTE À SUMMA DILIGENTIA DA UNIVERSIDADE: 0 RACIONALISMO CIENTÍFICO}

\footnotetext{
"Não devem esperar, no entanto, ouvir a boa notícia de que a luta contra a psicanálise terminou, e que esta, afinal, foi reconhecida como ciência e aceita como tema de ensino nas universidades." (Sigmund Freud, 1932, p. 137)
}

O debate em torno da legitimidade do ensino da psicanálise na universidade apresenta uma estreita relação com a questão do lugar em que esta ocupa no plano do conhecimento. No ambiente universitário, definir se determinada disciplina possui o mérito científico significa distingui-la das chamadas pseudociências ou de outros saberes (no sentido frouxo do termo saber), conseqüentemente, merecendo maior ou menor crédito dos estudantes, professores e pesquisadores. Em última instância, o discurso científico vem interditar o uso de procedimentos que the são alheios e a circulação de pensamentos estranhos à sua linguagem, através de um conjunto de critérios considerados racionais e empíricos.

Tais critérios deixam-se resumir grosso modo como: apresentar evidências que dêem plausibilidade aos pressupostos, explicitar as variáveis em jogo, formular um corpo teórico com coerência interna, ter capacidade de prever resultados, se possível propor experimentos replicáveis e falseáveis, e numa comparação com teorias rivais, criticar e explicar as insuficiências do adversário, explicar os sucessos do adversário, propor hipóteses novas com maior poder explicativo do que a dos adversários e com maior capacidade de articular fatores entre si e capaz de gerar mais previsões. (Hanns, 2000, p. 185)

O marco inicial do interesse pela demarcação dos critérios que 
regulamentam o campo da produção de conhecimento, como é sabido, data da subversão da cultura medieval e pela irrupção da ciência moderna, entre os séculos $X V$ e XVIII. Entre o final do século XIX e o início do século XX, são as chamadas ciências humanas que vêm reclamar o direito pela cientificidade reconhecida.

Se por um lado, há, atualmente, no contexto internacional, um esforço de várias correntes do meio psicanalítico de aproximar-se da universidade, obter reconhecimento acadêmico e, se possível, científico, visando influenciar as regulamentações e garantindo alguma legitimação acadêmica e social ${ }^{14}$. Por outro lado, permanece uma forte oposição na sociedade científica com relação ao reconhecimento da cientificidade das proposições psicanalíticas. Discussões em torno do mérito psicanalítico atingem diferentes populações, algumas fortemente fundamentadas em critérios estabelecidos pela Filosofia da Ciência, outras que parecem refletir uma resistência conhecida pelos psicanalistas há mais de um século, na maioria das vezes, associada à recusa da sexualidade como um elemento essencial à compreensão do funcionamento psíquico. O Prêmio Nobel Gerald Edelman, neurobiologista norte-americano, considera que o anti-freudismo está muito mais relacionado a uma resistência dos cientistas ao seu próprio inconsciente, do que com uma discussão científica (apud Roudinesco, 2000).

No esforço de encontrar vulnerabilidades, quase todos os dias são publicados textos das mais variadas influências que pretendem expor enganos e fragilidades nas construções teóricas, chegando, até mesmo, a explorar escândalos envolvendo supostos eventos da vida particular de Freud, no intuito de esvaziar qualquer mérito da criação a partir da "moral" de seu criador.

Nesse contexto, em defesa da psicanálise, psicanalistas engajados em soluções interpretativas das diferentes concepções de ciência buscam apoio num novo paradigma filosófico que, como argumentam, não mais

\footnotetext{
${ }^{14}$ Em nota de rodapé, Luiz Hanns fornece as seguintes informações: "Tanto a IPA como as principais instituições lacanianas têm orientado seus membros a aproximarem-se da universidade e a IPA oferece hoje subsídios para pesquisas empíricas de cunho científico que visem fundamentar a psicanálise cientificamente. (...) Gestaltistas, junguianos, rogerianos, humanistas, etc., todos enfrentam
} 
pretende uma verdade fixa e imutável. Outros questionam a negativa pelo reconhecimento da cientificidade da teoria psicanalítica, aplicando os próprios critérios científicos estabelecidos por alguns filósofos (como os de Thomas Kuhn e de Larry Laudan). Estes conjugam os paradigmas psicanalíticos com os científicos.

Também há os que atribuem à psicanálise um estatuto de contraciência. Munidos dos mesmos elementos que compõem a discussão filosófica dos critérios de cientificidade, localizam uma posição anterior ao fazer ciência, no cerne da concepção de conhecimento (o pensamento, ou cogito), do problema da racionalidade, onde encontram o lugar da psicanálise: a ante-sala da ciência. Um pouco próximos a esse posicionamento estão os que afirmam a psicanálise como uma derivação da ciência, um rompimento discursivo.

Outra defesa, distinta dos propósitos dos anteriores, é representada por um grupo de psicanalistas que se mantém isolados de tais debates, aparentemente indiferentes à problemática epistemológica, ou desconfiados de que o reconhecimento da influência das variáveis políticas e sociais possa se caracterizar num empreendimento falido de antemão, ou, ainda, desacreditam na prática do ensino de psicanálise, quando não há experiência do ouvinte com a análise. Postura que pode ser compreendida como um mero anticientificismo ou como uma suposta fidelidade a um pretendido caráter enigmático dos textos psicanalíticos e refratários aos leitores não-psicanalistas. Terminam por não questionar ou debater a teoria e os conceitos que acreditam guiar seu suposto único interesse: a prática clínica. A recusa desses psicanalistas ao diálogo com outros campos do conhecimento abrange, inclusive, o principal objeto desta pesquisa: a educação.

Caberia, provavelmente, pensar-se numa distinção entre um ensino exotérico da psicanálise, e um ensino esotérico: o primeiro, exotérico com " $x$ ", permite identificar o grupo disposto ao debate com outros campos: 
transmitido ao público sem restrição, dado ao interesse generalizado que suscitava e a forma acessivel em que podia ser exposto, por se tratar de ensino dialético, provável, verossímel (Ferreira, 1999, p. 861).

O segundo, esotérico com "s", em que se situam tais psicanalistas resistentes ao diálogo:

\footnotetext{
Diz-se do ensino que, em escolas filosóficas da Antiguidade grega, era reservado aos discípulos completamente instruídos. 2. P. ext. Todo ensinamento ministrado a círculo restrito e fechado de ouvintes (idem, $p$. 808).
}

Todas estas posturas são, por vezes, compreendidas como desafios de poder dentro das instituições ou entre instituições, que muitas vezes terminam por desqualificá-las.

\begin{abstract}
Disso não decorre, porém, a conclusão por antecipação de que toda articulação entre Psicanálise e Ciência constitua, obrigatoriamente, o esconderijo das influências ideológicas sorrateiras; tampouco, que o território do misticismo seja o refúgio, por excelência, da virtude e da verdade; e, muito menos, que a ausência da cientificidade constitua uma espécie de atestado de "pureza ideológica" (Pacheco Filho, 2000, p.38).
\end{abstract}

Safouan, Julien e Hoffmann (1996) identificam três respostas à pergunta sobre a natureza da relação da psicanálise com os outros saberes: na primeira, transformada em gueto, a tese freudiana é situada na exterioridade científica e cultural, ninguém, além do analista, estaria habilitado a dizer nada de válido sobre a psicanálise, uma exceção às regras (à moda do judaísmo de Freud); na segunda, "missionária", a psicanálise julga tudo, dá lições e distribui valores, ocupando uma posição de supervisão e dom, enquanto os psicanalistas estariam na condição de não castrados.

Essas duas respostas, mesmo contrárias, estariam apoiadas numa mesma idéia: a auto-suficiência. O que, nesse caso, expõe uma resistência também nociva à intenção de contribuição entre psicanálise e educação.

Uma terceira resposta, segundo os autores, confere à psicanálise um caráter parasitário de sua existência lingüística e a destitui de palavras que Ihe sejam próprias. Assim, a cada conexão, teria sua prática, seus conceitos e seus obstáculos renovados. Não se pode negar que esta seria a fonte de 
possíveis distorções da psicanálise em muitos campos, inclusive no campo educativo.

Não pretendendo medir a potência dos discursos em questão, o presente texto tampouco tem como objetivo refutar ou colaborar com uma ou outra afirmação, mas apenas expor alguns dos diferentes caminhos trilhados por autores preocupados em desvencilhar a teoria e a prática psicanalítica de uma imobilidade em relação aos outros campos do conhecimento, mantendo-a em diálogo com a ciência atual, bem como com o pensamento contemporâneo. Diálogo que parece condição de "esclarecimento de pontos cegos, zonas de obscuridade e miopia e fontes de erro presentes na busca de conhecimento; também, eventualmente, as formas de ultrapassagem e superação de impasses" (Pacheco Filho, 2000, p. 38).

\section{Os novos paradigmas científicos: o inconsciente e o átomo}

Um dos maiores físicos nucleares do mundo, Prêmio Nobel em 1932, Werner Karl Heisenberg (1901 - 1976), ao debater sobre os pontos fundamentais e os problemas filosóficos da teoria quântica, levantou a necessidade de se derrubar as bases da física clássica e erguer um novo edifício científico. Sinteticamente, isto implicou, de início, na alteração da maneira de descrever os movimentos em nível atômico (mudança que caracterizou a mecânica quântica); depois, em se descrever a relação entre o resultado de uma medição e a perturbação causada sobre ele pelo observador.

Assim como toda observação perturba o sistema observado, as perturbações introduzidas no processo de medição não podem ser calculadas no campo microscópico. Isto é, ao se fazer uma medição, perturba-se de tal forma o sistema que se torna impossível fazer uma previsão exata sobre seu comportamento futuro, sendo possível apenas estabelecer a probabilidade de que algo aconteça. A formulação mais completa desta proposição de Heisenberg é designada por Princípio das Incertezas (Ferracini, 1996). 
Aceito, aparentemente, pela maioria dos cientistas, o Princípio das Incertezas formou a base da filosofia da ciência, que considera inerente à própria natureza a impossibilidade de prever fenômenos, porém, não como uma deficiência humana ou experimental.

Há um argumento comum entre os que se dedicam ao debate sobre a ciência e o lugar da psicanálise no campo do conhecimento: as revoluções científicas que caracterizaram o início do século $X X$, especialmente as transformações dos conceitos e objetos no interior da física e a teoria da relatividade, rompem com a pretensão da busca de uma verdade e de uma realidade fixas e imutáveis, revolucionam a concepção de métodos científicos, oferecem um novo paradigma científico, um novo modelo para a ciência, onde, se acredita, a psicanálise tem seu lugar.

Em linhas gerais, na evolução da ciência do século $X X$, com o desenvolvimento da física relativista,

... os processos e eventos foram tomando o lugar dos objetos; os processos irreversíveis, o lugar dos reversíveis; o devir e a mudança, o lugar do ser e da permanência; as noções de destino, liberdade e espontaneidade, o das de causalidade, determinismo, mecanicismo e racionalidade; as de interação e informação, a de causalidade unilateral isolada; e a de acaso, a da ordem (de uma ordem primeira) (Rolim, 2000, p. 8).

Dentre as repercussões das novas referências do fazer ciência encontra-se o reconhecimento do papel do experimentador como intérprete da verdade e da realidade dos fenômenos. Diferente do mero papel de observador presente na física clássica, na física quântica o experimentador é também sujeito em seu experimento (idem, p. 9). Isso significa considerar que aquele que observa, escuta, descreve e julga sabe menos do que aquele que é observado. E, enquanto a física começa a constatar que o sujeito observador interfere no objeto observado, a psicanálise já “.... denunciava as ilusões egóicas da própria noção de sujeito, remanescente da certeza do eu pensante cartesiano" (Saporiti, 1994, p. 11). Isso, obviamente, ultrapassa uma possível interpretação ingênua que se refira à "substância 
psicológica" do cientista, isto é, para a Psicanálise não se trata de uma realidade psicológica que acomoda um novo conhecimento, mas um "eu que não pensa e não diz", que é "pensado e dito pelo saber" que ele pretende controlar.

Nesse novo cenário científico, as proposições psicanalíticas obedecem à mesma ordem das outras ciências da natureza. Além da questão do deslocamento do saber do experimentador para o saber que sabe o observador, torna-se possível traçar alguns outros paralelos, como faz Ana Maria Rolim (2000): a descoberta da função da fantasia sobre o psiquismo, redimensiona a importância da rememoração do real vivido, assim como o elétron que, dependendo da forma como se o mede, pode se mostrar ora como partícula ora como onda, impossibilitando sua definição. Dessa forma, ambos os campos prescindem de uma anterioridade essencial na determinação de um fenômeno (um pensamento inconsciente ou um evento físico subatômico). As propriedades dos pensamentos inconscientes e dos elétrons são definidas a posteriori e carregam a marca da presença do experimentador ou analista.

Outro paralelo: a idéia de tempo absoluto foi abolida da psicanálise desde os seus primórdios. O tempo de um sujeito é singular, portanto, intemporal, tal como se apreende da teoria do complexo de Édipo.

\footnotetext{
E o que dizer do $2^{\circ}$ princípio da Termodinâmica, a entropia? Ao retomar, em 1967, aquela matéria que Planck flagara "privilegiando" certos estados que a "atraem", Prigogine conclui que a produção de entropia contém dois elementos sempre ligados (dialéticos): um, criador de desordem e, outro, de ordem. A coexistência de tempos diferentes e articulados - um que desagrega e outro que agrega - retira do caráter irreversível da entropia o papel negativo e depreciado que ele até então desempenhara. (...) Enquanto a ordem era vista, pela ciência e pela filosofia, como primeira e essencial, a desordem era vista como degradação da ordem preexistente $e$, portanto, como não-equilíbrio, como acidental e contingente, como morte (Rolim,2000., p. 10).
}

Apesar das revoluções internas, talvez se defendendo contra 0 desconhecido, é possível perceber uma resistência das ciências que continuam operando a partir de concepções reguladas pelo paradigma do sujeito cartesiano. Por sua vez, o caráter subversivo da psicanálise, segundo Saporiti, não define somente outro olhar do homem para si próprio, como também impõe a submersão do olhar do cientista sobre o que faz. A 
psicanálise traz, portanto, um novo "modo de pensar" (1994, p. 11). ${ }^{15}$

Essencialmente, o que se coloca em discussão é que a comunidade científica tem apresentado uma condição para o reconhecimento da psicanálise: que ela se ajuste a critérios de verdade que nada tem a ver com a sua verdade que, por sua vez, não absoluta, confunde-se com a idéia de ficção (tema que reaparecerá em outros pontos deste trabalho). Em linhas gerais, para a psicanálise, a verdade não é a apreensão absoluta do real (se este não fosse irredutível), tampouco uma totalidade.

Saporiti (1994) acredita numa possível solução para esse impasse: deixar as referências de críticos racionalistas, representadas principalmente pelo teórico Karl Popper ${ }^{16}$, e acatar o critério extraído das teorias de Charles S. Peirce ${ }^{17}$. Propõe-se aqui, então, uma explanação rápida e despretensiosa do que os referidos teóricos defendem.

Antes, porém, de apresentar alguns poucos elementos da noção popperiana de ciência e de racionalidade, vale assinalar um interesse inicial de Popper pela psicanálise:

\begin{abstract}
... Após o colapso do Império Austríaco, a Áustria havia passado por uma revolução: a atmosfera estava carregada de slogans e idéias revolucionárias; circulavam teorias novas e freqüentemente extravagantes. Dentre as que me interessavam, a teoria da relatividade de Einstein era sem dúvida a mais importante; outras três eram a teoria da história de Marx, a psicanálise de Freud e a "psicologia individual" de Alfred Adler.

... Durante o verão de 1919, comecei a me sentir cada vez mais insatisfeito com essas três teorias... passei a ter dúvidas sobre seu status científico. (Popper, 1972, p. 64)
\end{abstract}

Se na concepção atual de cientificidade permanece uma marcante

\footnotetext{
${ }^{15}$ Nesse caso, o novo modo de pensar que a psicanálise traz atingiria os critérios de cientificidade. Noutra leitura, apresentada no próximo tópico, o pensar psicanalítico estaria numa posição anterior às ciências naturais.

16 “O físico e filósofo austríaco Karl Raimond Popper (1902-1994), exilado na Nova Zelândia após a ascensão do nazismo e depois radicado na Inglaterra, tornou-se um dos mais conhecidos filósofos da ciência de nossa época. Participou inicialmente do famoso Círculo de Viena, construindo depois uma concepção pessoal da metodologia científica, procurando desmontar sobretudo a habitualíssima prática de verificação de hipóteses..." (Turato, 2003, p. 71).

17 "Uma concepção completamente diferente da do positivismo dá forma à filosofia de C. S. Peirce (1839-1914). Enquanto Comte descartara as hipóteses como metafísicas, Peirce, ao contrário, pretendia demonstrar que a elaboração de hipóteses é uma atividade vital, com lógica própria. A obra de Peirce é volumosa e fragmentária. Além disso, ele muitas vezes lutou com problemas difíceis e sugestões novas. Portanto, não é fácil conseguir uma visão clara de sua posição. Contudo, não resta dúvida de que foi uma das mentes mais originais do final do século XIX e, certamente, o maior pensador americano de todos os tempos" (Russell, 2001, p. 398).
} 
fundamentação apoiada no racionalismo ${ }^{18}$ crítico, Popper destaca-se como referência na formulação dos critérios a que toda teoria que se pretenda científica deve obedecer. $\mathrm{O}$ eixo das críticas que se voltam às teorias é o critério de refutabilidade. Segundo Popper, o critério de verificabilidade através do método científico tradicional (observação e indução) deveria ser substituído pelo critério de demarcação da falseabilidade (refutação) ${ }^{19}$. Em linhas gerais, para esse teórico, demarcando o limite entre o que é e o que não é científico encontra-se a possibilidade de refutação da teoria, isto é, ela própria deve permitir experimentos que possam dar desmentidos parciais e indiretos. Portanto, a distinção entre o metafísico ou ideológico e o científico, não é o fato de que o primeiro seja falso, mas sim que ele é concebido de maneira que se torna impossível provar seu falseamento: "... como no exemplo da física, que é verdadeiramente ciência porque faz predições que a experiência pode contradizer" (Turato, 2003, p. 73). Sendo caracterizada como uma postura crítica, uma postura da procura do erro, segundo Popper, a postura científica não vem questionar o sentido lógico da psicanálise. No entanto, as interpretações psicanalíticas, baseadas essencialmente em observações clínicas, não possibilitam experimentos que a refutem, pois, o crivo científico encontra uma grande "falha" na teoria psicanalítica: os fatos a confirmam sempre.

Para demonstrar sua afirmação, Popper recorre a um exemplo: um homem pode tanto salvar uma criança de afogamento, quanto pode afogá-la e, em ambos os casos, a psicanálise oferecerá explicações, o que a tornaria irrefutável (Popper, 1972, p. 65). Aqui, no entanto, Günbaum (1984, apud Marinho, 2001) expõe a insuficiência do exemplo: há uma preocupação de Popper em alcançar uma teoria psicológica que não diferenciasse dois homens, ou o mesmo homem em situações diversas; desaparece a noção de singularidade da situação e do sujeito; em suma, uma ciência que seria incompatível com o fenômeno humano.

\footnotetext{
18 "No sentido metafísico, doutrina Segundo a qual nada existe que não tenha a sua razão de ser, de tal maneira que por direito, senão de fato, não há nada que não seja inteligível. (...) Doutrina segundo a qual todo conhecimento certo provém de princípios irrecusáveis, a priori, evidentes, de que ela é conseqüência necessária e, por si sós, os sentidos não podem fornecer senão uma ideia confusa e provisória da verdade (Descartes, Espinosa, Hegel)" (Lalande, 1999, p. 910).

${ }_{19}$ No entanto, segundo Luiz Hanns (2000), muitas das hipóteses da Psicanálise são falseáveis, na medida em que tendências podem ser testadas em amostras suficientemente grandes.
} 
Marinho (2001) acredita que Popper nunca tenha se libertado de um cientificismo que caracteriza a primeira fase de sua obra, quando o critério de demarcação entre ciência empírica e não-empírica se estende ao critério de demarcação entre o racional e o irracional. Confundindo, portanto, cientificidade com racionalidade.

Buscando outro modelo de pensamento filosófico, para Pierce:

\begin{abstract}
A verdade é o que alguém faz com as suas próprias declarações. (...) Na discussão da lógica das hipóteses, Peirce deu uma contribuição fundamental. (...) As hipóteses resultam num terceiro processo lógico, radicalmente diferente [da dedução e da indução], que Pierce, no seu costumeiro estilo pitoresco, chama de 'abdução'. Isto equivale a adotar tentativamente uma hipótese porque salva alguma aparência particular (Russell, 2001, p. 400).
\end{abstract}

Na teoria peirceana é notória a tensão entre o real "existente" e o real "possível ou potencial", assim como as tensões: simetria / assimetria, temporalidade / atemporalidade, reversibilidade / irreversibilidade, continuidade / descontinuidade... "todos eles pares que compõem o nosso mundo quer seja o exterior, quer seja o interior, do nosso psiquismo que, para Peirce, não é tão diferente assim do externo, pois ambos seriam feitos de um mesmo estofo" (Saporiti, 1994, p. 125).

Em suma, a partir da leitura de Saporiti (1994), enquanto Popper se apóia numa lógica pautada nas noções de "verdade" e "falsidade" para avaliar a cientificidade da psicanálise, a teoria de Peirce parece convergir com a noção de verdade psicanalítica, na medida em que incorpora a "incerteza" (hipótese), possibilitando que as noções de espontaneidade e determinismo possam conviver sem serem antagônicas.

\title{
A psicanálise sob o olhar da epistemologia das ciências
}

"Se Freud transitava tão despreocupadamente entre esses domínios 
[psíquico e somático], isso é muito mais um indício de que não se está trabalhando com as idéias tradicionais do que outra coisa." Assim, Luiz Roberto Monzani (1991, p. 127) redireciona a discussão em torno da contribuição de Freud às chamadas ciências humanas. Em linhas gerais, uma compreensão que há tempos vem oscilando entre, por um lado, a concepção naturalista, determinista, mecanicista e, por outro lado, uma pesquisa do sentido, como interpretação. Monzani expõe as deformações e os fracassos nas leituras realizadas através de critérios que são estranhos ao discurso psicanalítico: materialismo, fenomenologia, existencialismo, etc.

$O$ autor afirma a necessidade de que seja feita uma leitura interna do discurso psicanalítico, "examinar seus contornos próprios, suas linhas de projeção, a articulação das teses entre si, o modo de validação, etc" (idem, p. 126), paralelamente, a preocupação em abandonar hábitos inveterados, resistências que fazem com que o crítico seja insensível e tome certas ordens como eternas. Em relação à linguagem biológica de Freud, por exemplo, Monzani observa que é sabido que uma ciência que está nascendo tende a tomar emprestado o vocabulário de outra já existente. Em sua perspectiva, o crítico deve ser capaz de considerar isso.

Distinto do projeto da Filosofia da Ciência, que se impõe aos saberes como detentora dos critérios válidos a toda disciplina que se pretenda científica, a Epistemologia das Ciências, apesar de também pretender investigar os procedimentos de uma disciplina, parte do ponto de vista "de que cada domínio científico tem seu contorno e sua especificidade própria e que é inútil tentar instaurar um ideal unitário de ciência" (ibid., p. 131). Há, portanto, duas maneiras distintas do discurso filosófico se relacionar com o discurso psicanalítico e uma epistemologia da psicanálise, mesmo distante de trazer conclusões, tem se revelado bastante frutífera, na percepção de Monzani.

Somente a partir de uma leitura desprovida de preconcepções científico-filosóficas é que se permite compreender o sujeito "revelado" pelo discurso psicanalítico. A qual concepção de sujeito, Monzani se refere? O sujeito tomado daí não se assemelha com a substância psicológica que, como cientista, reflete o saber das coisas e, sob o título de professor, traduz essas mesmas coisas com perfeição. Tampouco se relaciona com aquele do 
qual se espera acomodar, com a mesma perfeição, o saber das coisas num organismo em desenvolvimento, porque, por exemplo, é aluno.

Por intermédio da linguagem, o sujeito estabelece certo número de relações estáveis, porém, no interior dessas relações inscreve-se algo muito mais amplo do que se percebe em seu enunciado, que the diz respeito exclusivamente.

\section{$\mathrm{Kuhn}^{20}$ e a ciência normal}

A partir do texto ${ }^{21}$ de Raul Albino Pacheco Filho (2000), intitulado O método de Freud para produzir conhecimento: revolução na investigação dos fenômenos psíquicos?, neste segmento, propõe-se, por um lado, uma incursão aos pressupostos de Thomas Kuhn sobre os critérios de cientificidade, suas críticas dirigidas à psicanálise e, por outro, a aposta de Pacheco Filho no aceite da psicanálise pelos mesmos critérios estabelecidos por Kuhn.

Sua concepção de ciência questiona as posições epistemológicas mais ortodoxas em diversos aspectos, entre os quais, apenas para citar um exemplo de interesse especial para a discussão da cientificidade da Psicanálise, a concepção de uma diferença radical entre fato e teoria, que permitisse o estabelecimento de procedimentos de coletas de dados empíricos "puros", absolutamente independentes da influência $e$ "contaminação" do ponto de vista teórico do pesquisador (Pacheco Filho, 2000, p. 238).

Em Lógica da descoberta ou psicologia da pesquisa?, de 1970, comparando à astrologia, Kuhn desqualifica a psicanálise do conjunto das disciplinas científicas por não atender às características do que intitula ciência normal, a saber, por não gerar atividades de solução de enigmas ou

\footnotetext{
${ }^{20}$ Thomas Samuel Kuhn (1922-1996) nasceu em Ohio (EUA). Entre 1940 e 1943, estudou física na Universidade de Harvard, onde doutorou-se em 1949. Migra para o Departamento de Filosofia da Universidade da Califórnia, em 1956. Ali permanece até 1964, quando passa a exercer a função de professor de filosofia na Universidade de Princeton, até 1979. Trabalhou num projeto de documentação da história da mecânica quântica. Foi presidente da Sociedade Norte-Americana de História da Ciência (1969 a 1970) e da Associação Norte-Americana de Filosofia da Ciência (19891990). Ao longo de sua carreira, recebeu prêmios importantes (Mendonça; Videira, 2002).
} 
de resolução de quebra-cabeças (apud Pacheco Filho, 2000). Essas seriam as características que constituem o critério científico, na perspectiva de Kuhn, no lugar da refutação de Popper.

Segundo Kuhn, a sucessão dos acontecimentos no interior da ciência acompanha os seguintes períodos: o pré-paradigmático, em que diferentes escolas competem, num debate, pelo domínio na área de estudo de um universo comum entre elas; o de crise e pesquisa extraordinária, que entrecorta todos os demais períodos e se caracteriza pelo surgimento de novos paradigmas, estes compreendidos como um conjunto de realizações modelares de investigação, composto por lei, teoria, aplicação e instrumentos de pesquisa; o ápice desses períodos seria o das revoluções científicas, que consistiriam em episódios e investigadores extraordinários que "conduziriam a comunidade da disciplina a um novo conjunto de compromissos de investigação, que subverteriam a tradição de pesquisa da área ditada pelo paradigma anteriormente vigente" (idem, p. 242).

No período pré-paradigmático, os cientistas estariam absorvidos pelo debate, levados a concentrar esforços na discussão sobre os fundamentos (princípios filosóficos, metodológicos e epistemológicos) do seu campo de estudo; portanto, furtando-Ihes a dedicação à investigação do seu universo de pesquisa. A superação desse período significaria para a disciplina um grande triunfo, pois, permitindo maior dedicação à pesquisa, facilitaria seu progresso.

É nesse período pré-paradigmático que Kuhn localiza o campo de pesquisa sobre o psiquismo, portanto a psicanálise. Para superá-lo, a disciplina deveria demonstrar capacidade para solucionar problemas reconhecidamente relevantes. Assim, a ciência normal se caracterizaria pelo cumprimento da "promessa" de solução de tais problemas relevantes e, quando a disciplina frustrar as expectativas sobre ela (mecanismo de afrouxamento de regras e diretrizes da pesquisa), haveria mais um momento de evolução na sucessão dos acontecimentos científicos.

$\mathrm{Na}$ interpretação de Pacheco Filho, a psicanálise se enquadra nas características da ciência normal de Kuhn. Em primeiro lugar, propondo leis

\footnotetext{
${ }^{21}$ Um dos capítulos que compõem Ciência, pesquisa, representação e realidade em psicanálise. Livro que Raul Albino Pacheco Filho organizou, junto com Nelson Coelho Junior e Miriam Debieux Rosa.
} 
e teoria sobre os fatos psíquicos, construção de método para sua investigação e proposta de aplicação (intervenção psicoterápica), segundo o autor, a psicanálise deve ser considerada um paradigma.

Um paradigma instalado no campo da disciplina criaria uma tradição de pesquisa que estabeleceria quatro definições. A primeira seria a definição das entidades fundamentais que comporiam o universo de estudo da disciplina e que poderiam constituir objetos apropriados de estudo. Pacheco Filho destaca algumas das entidades fundamentais da Psicanálise que a diferencia das demais abordagens da psicologia do final do século XIX:

... as manifestações do inconsciente, a sexualidade infantil e demais eventos e processos a eles relacionados: entre eles, o recalque, a resistência, a transferência, o complexo de Édipo, e o complexo de castração, apenas para citar os mais importantes (2000, p. 250).

A segunda definição designaria o modo de interação entre as entidades fundamentais e de como poderiam ser captadas pela percepção do cientista. Pacheco Filho identifica como exemplo dessa definição de interações as concepções psicanalíticas de sobredeterminação ${ }^{22}$ e de séries complementares ${ }^{23}$ : "o inter-relacionamento interativo e complexo entre numerosos processos é um dos pressupostos essenciais da psicanálise, a respeito do modo de interação entre os fatores pertencentes a seu domínio" (idem, p. 251).

O paradigma deveria, também, definir questões que evidenciassem a imposição de problemas na investigação científica sobre as entidades fundamentais. Esta, a terceira definição, estaria presente na psicanálise, segundo Pacheco Filho, em diferentes momentos da história da teoria, como exemplo, cita um trecho do texto $O$ Inconsciente, em que Freud expõe o problema da explicação metapsicológica, que exigiria uma descrição ainda inexistente do processo psíquico em três dimensões: dinâmica, topográfica e

\footnotetext{
22 “Termo empregado em filosofia e psicologia para designar, conforme as modalidades próprias de cada objeto, uma pluralidade de determinações que geram um dado efeito. Essa palavra foi utilizada por Freud, em particular, na interpretação de sonhos" (Rodinesco; Plon, 1998, p. 718).

23 "Expressão utilizada por Freud para explicar a etiologia das neuroses e ultrapassar a alternativa que a obrigaria a escolher entre fatores exógenos ou endógenos: estes fatores são na realidade complementares, pois cada um deles pode ser tanto mais fraco quanto o outro é mais forte, de modo que um conjunto de casos pode ser classificado numa escala em que os dois tipos de fatores variam
} 
econômica.

Finalmente, como a quarta definição estabelecida pela tradição de pesquisa criada por um paradigma, Kuhn se refere à delimitação dos métodos e técnicas que poderiam conduzir a investigação sobre as entidades fundamentais, apropriadamente, no campo da ciência. Pacheco Filho relaciona a seqüência histórica dos métodos que a psicanálise criou, a fim de atender a investigação e a solução do sofrimento psíquico:

Do método catártico, passando pela técnica de pressão, até aos mais refinados desenvolvimentos posteriores do método psicanalítico, com sua abordagem hermenêutica e centrada na transferência e na interpretação, para a decifração dos fatos inconscientes, o que se observa é uma busca constante de novas e melhores maneiras de aproximação do seu objeto... (ibid., p. 252).

Guiando-se ainda pelas exigências kuhnianas na determinação de um paradigma, este deveria promover e dirigir uma dedicação à pesquisa de forma precisa, esotérica e extenuante. Pacheco Filho manifesta a convicção no intenso trajeto investigativo de Freud, como em sua "escuta exaustiva e aprofundada do que diziam seus pacientes, buscando compreender-lhes, no decorrer de longos processos de atendimento, os significados ocultos por trás da fachada de motivações e intenções racionais conscientes (...)" (ibid., p. 254). Freud era incansável na busca pelo significado de fenômenos considerados indeterminados por outros paradigmas (como se observa no estudo sobre os sonhos).

No conjunto das teses de Freud, o autor também evidencia atividades científicas com características de solução de enigmas ou quebra-cabeças, preconizadas por Kuhn, que realizariam a "promessa" de sucesso da psicanálise na solução de problemas relativos à explicação dos fenômenos psíquicos, seriam elas: a explicitação do processo de defesa psíquica contra representações conflitivas e angustiantes; revelações sobre as obsessões, as fobias e as neuroses; perversões, distúrbios de caráter, psicoses e manifestações psicossomáticas; além da compreensão mais profunda dos processos psíquicos que incluem os sonhos, a vida de vigília, os afetos, a percepção, a memória, a vontade, o pensamento, cultura e sociedade, entre 
muitos outros elementos, cuja aproximação resultou da combinação das atividades de observação empírica e reflexão teórica.

Ainda tratando das características de solução de enigmas ou quebracabeças, Pacheco Filho destaca a presença de regras na investigação científica empreendida pela psicanálise: apesar de manter seu posicionamento sobre as relações entre soma e psique como fenômenos interdependentes, Freud apresenta em suas pesquisas um deslocamento de concepções mecanicistas e reducionistas, para uma concepção mais psicológica, assim, o "desenvolvimento do conhecimento dos fenômenos psíquicos não precisa permanecer no aguardo de uma explicação neurofisiológica dos processos psíquicos" (ibid., p. 261). Também, destaca a prioridade dos dados extraídos das investigações no contexto da clínica psicanalítica, demonstrando que a procura de apoio nos fatos era, em Freud, uma imposição de coerência.

O segundo exemplo converge com outra característica de ciência normal que seria a integração entre fatos e teoria. Integração que Pacheco Filho não apresenta dificuldade em localizar, devido aos inúmeros relatos de casos que acompanham o desenvolvimento da teoria psicanalítica, desde os contidos em Estudos sobre a Histeria. "Essa crescente rearticulação da teoria e aperfeiçoamento dos conceitos, com uma progressiva integração com os dados da experiência, é inegável a marca do trabalho de Freud" (ibid., p. 265).

Para finalizar o debate estabelecido por Pacheco Filho, a partir do referencial de Kuhn, deve-se destacar uma última característica do trajeto da ciência normal: a pesquisa extraordinária que dá origem a uma revolução científica. $O$ autor lembra que apesar de passagens em que Freud perseguia o que o paradigma vigente indicava como relevante (por exemplo, as referências fisiológicas), foram justamente suas pesquisas que ultrapassaram as restrições estabelecidas que trouxeram uma revolução no conhecimento. Para tanto, destacou-se a importância da intuição na orientação de seu trabalho, que permite atribuir-lhe a característica de pesquisa extraordinária; além de certos traços de sua personalidade, dentre 
outras, sua insatisfação diante da perspectiva de uma carreira de importância mediana.

\section{Progresso e racionalidade em Larry Laudan}

Epistemólogo contemporâneo, norte-americano residente no México, Laudan realiza uma permanente tentativa de superar os impasses enfrentados no debate entre diferentes correntes, em torno da racionalidade da atividade científica, da escolha entre teorias e da noção de progresso.

Em Progress and its Problems - Towards a Theory of Scientific Growth, de 1977, Laudan levanta importantes questões diante do que qualifica de preconceitos culturais em favor da ciência na cultura moderna (apud Marinho, 2001), isto é, uma disposição em tomar a racionalidade e o progresso da ciência como um fato óbvio ou uma conclusão sem problemas.

Suas críticas, dirigidas a essa tendência moderna, estão apoiadas em quatro questões fundamentais trazidas por estudos recentes: a primeira repousa no fato de que os modelos de racionalidade definidos pela Filosofia da Ciência excluem praticamente toda atividade científica atual, forçando a percepção de toda ciência como irracional; a segunda se refere ao constante fracasso nas tentativas de mostrar que os métodos científicos garantem conhecimento verdadeiro, provável, progressista ou altamente confirmado, conduzindo, portanto, à conclusão de que as teorias científicas não são verdadeiras, não são prováveis, nem progressistas, tampouco confiáveis; a terceira, que considera a revelação de sociólogos da ciência sobre fatores históricos que levaram a decisões não racionais no campo científico; e a quarta, considera os trabalhos de historiadores e filósofos da ciência (dentre eles Kuhn), que afirmam a não racionalidade de certas decisões entre teorias e alegam serem, por natureza, irracionais as escolhas entre teorias competidoras, além disso, a noção de progresso é pouco precisa, na medida em que todo ganho de conhecimento implica perdas, o que torna impossível afirmar quando ou, mesmo, se há progresso.

Em síntese, Laudan faz ver a existência de um ceticismo alimentando 
os argumentos do relativismo cultural que, por sua vez, considera a ciência como um conjunto de crenças (dentre tantas) e que interpreta a apologia da ciência no Ocidente como produto de uma cultura que se estabeleceu pelo desenvolvimento científico. Uma interpretação como essa coloca a ciência no mesmo campo dos dogmas e ideologias, em que a objetividade e a racionalidade são impossíveis.

Suas propostas para solução dos impasses que se colocam diante de filósofos e epistemólogos da ciência passam pelo questionamento da subordinação tradicional do progresso à racionalidade científica, atentando ao caráter temporal do conceito de progresso em oposição ao caráter atemporal da racionalidade. Isto implica numa necessária inversão, no sentido em que a racionalidade científica revela-se pela escolha da teoria mais progressista.

A tese que mais distingue o trabalho de Laudan talvez seja sua definição de ciência como sendo essencialmente uma atividade de resolver problemas. Tratando tanto dos problemas empíricos, que "pretendem falar sobre o mundo e surgem no contexto de investigação de uma teoria" (Marinho, 2001, p. 77), quanto conceituais, que são definidos "por exclusão: são não-empíricos" (idem, p. 77); considera que os problemas científicos não diferem de qualquer outro tipo de problema: "Vê os problemas como as questões da ciência, enquanto as teorias seriam suas respostas" (ibid., p. 76). Logo, para se dizer de uma ciência, é necessário saber se ela fornece soluções satisfatórias para problemas importantes antes de perguntar se é verdadeira, confirmada e justificada pela epistemologia.

A fim de evitar confusões, Laudan especifica o que está designando por problema. Um problema é reconhecido como tal em um determinado tempo, assim, por motivos racionais, deixa de sê-lo em tempos posteriores; diferente de um fato que resta sem transformações. Segundo o autor, somente dessa forma podemos explicar a maior parte da atividade teórica que ocorreu na história (apud Marinho, 2001).

Desde Popper, passando por Kuhn, Laudan critica os filósofos da ciência por ignorarem o papel dos problemas conceituais, tratando-os como demonstrações de irracionalidade da ciência. Disso resulta, segundo ele, a falta de ajuste às epistemologias empiristas da ciência que, 
reconhecidamente, "têm ditado moda por mais de um século" (Laudan apud Marinho, 2001).

Apesar de concordar com boa parte do trabalho de Kuhn, a concepção de progresso representa uma importante diferença entre os autores. Como foi anteriormente analisado, para Kuhn, a evolução do conhecimento científico dá-se pela superação de paradigmas, portanto, é marcada por revoluções. No entanto, baseando-se um estudo retrospectivo, as "revoluções científicas", na perspectiva de Laudan, não foram tão revolucionárias como aparentam. Logo, discordando da chamada "ciência normal" (Kuhn), que pressupõe um paradigma dominante, Laudan afirma sempre terem existido disputas entre tradições de pesquisa e questionamentos sobre os fundamentos da ciência. O que levou, inclusive, a uma tradicional resistência por parte dos cientistas, diante de uma nova tradição de pesquisa.

Acrescenta-se aí a crítica de Laudan à ideia de Kuhn de que, no período de maturidade, o paradigma esteja imune a influências externas; assim como a exigência de Popper de aumento do conteúdo empírico, na medida em que uma nova teoria deva resolver problemas anteriores e novos.

Embora identifique imperfeições na teoria de Laudan, como a de deixar em segundo plano o problema da linguagem, Marinho a considera capaz "de superar muitas das insuficiências que encontramos na epistemologia popperiana, quando aplicada à teoria psicanalítica" (idem, p. 96). Ainda mais, dentre outras possibilidades que destaca na fundamentação de Laudan para o status epistemológico da psicanálise, Marinho menciona o espaço de reflexão para as relações entre "visão de mundo" e ciência; a centralidade da eficácia na solução de problemas como critério na avaliação das propostas científicas; o conceito de tradição de pesquisa, que possibilita pensar numa tradição freudiana ou, como prefere Marinho, tradição psicanalítica.

Finalmente, Marinho vê grande parte dos objetos de investigação psicanalítica (afetos, sonhos, lapsos), que encontram restrições na tradição popperiana, numa perspectiva diferente em Laudan, frente ao peso atribuído à noção de problemas conceituais em qualquer empreendimento científico. 


\section{A psicanálise como contraciência}

Verifica-se no trabalho de Foucault uma insistente aparição da teoria psicanalítica, a partir de confrontos e interrogações permanentes sobre seu sentido e o lugar ocupado no pensamento ocidental. Sua apreciação se desloca em redes de relações e em diversos desenhos de significação.

O inquietante é que este questionamento venha a cada vez de outro lugar: ora é a consistência epistemológica da psicanálise que é posta em xeque, ora sua inserção no social, ora a existência mesma dos objetos que estuda, ora o sentido e o alcance das teorias que a especificam (Mezan, 1988, p. 185-186).

A partir de uma arqueologia da loucura e de uma genealogia da sexualidade no Ocidente, Foucault analisa a construção histórica das práticas discursivas que abrangem o registro político e o registro ético. Inscrevendo a psicanálise nesses dois campos, confere a ela um estatuto político: uma ética na vontade de poder. Enquanto Lacan, com a introdução da lingüística de Saussure e a concepção de simbólico de Lévi-Strauss, concebe a Psicanálise como uma ética: uma ética do desejo (Birman, 1994, p. 63). Dentre outros autores, franceses em sua maioria, Foucault e Lacan deslocaram a problemática da cientificidade da psicanálise e inseriram-na no campo da cultura, mais propriamente, como interpretação.

\footnotetext{
Pode-se dizer que a filosofia, no mundo ocidental, havia, às cegas, e de algum modo em falso, na obscuridade, na noite de sua própria consciência e de seus métodos, circunscrito um domínio, aquele que ela chamava de alma ou de pensamento e que, agora, serve de herança a ser explorada pelas ciências humanas de um modo claro, lúcido e positivo. De modo que as ciências humanas ocupariam, com todo o direito, esse domínio um pouco vago que fora assinalado, mas abandonado como terreno inculto pela filosofia. (Foucault em entrevista com A. Badiou, produzida pela rádiotelevisão escolar, em 27 de fevereiro de 1965) ${ }^{24}$
}

A novidade que Foucault identifica no campo das ciências humanas é que a descoberta freudiana sobre 0 inconsciente desloca as tradicionais referências fisiológicas e sociais, para uma discussão em torno do problema

${ }^{24}$ In: Problematização do Sujeito: psicologia, psiquiatria e psicanálise / Michel Foucault; organização Manoel Barros da Motta. Rio de Janeiro: Forense Universitária, 1999, p.200. 
do conhecimento, situado nos limites da racionalidade. A partir de LéviStrauss e dos primeiros textos de Lacan, Foucault considera que, tanto à filosofia quanto às ciências humanas, não bastava mais dizer, ora como uns, que o sujeito era radicalmente livre e, ora como outros, que o sujeito era determinado por condições sociais (Foucault, 1999).

As ciências humanas passam não mais a analisar o que o homem é em sua natureza, mas passam a considerá-lo como fonte das representações que exprimem suas relações com a vida, com o trabalho e com a linguagem.

\footnotetext{
Mas por outro lado, para Freud, o inconsciente tem uma estrutura de linguagem. Não se deve esquecer, no entanto, de que Freud é um exegeta e não um semiólogo; é um intérprete, e isso não é um gramático. Enfim, seu problema não é um problema de lingüística, é um problema de deciframento (Foucault, 1999, p. 202).
}

A linguagem é considerada por Foucault como a contraciência capaz de unificar o campo das ciências humanas. Portanto, coloca a obra de Freud em um lugar privilegiado: sua posição no conjunto dos saberes que organizam a episteme de nossa época.

\footnotetext{
A uma pergunta do filósofo Badiou sobre a possibilidade de a psicologia ser capaz, como as ciências exatas, de fazer sua própria filosofia, responde que este papel cabe, nas chamadas ciências humanas, à psicanálise e à antropologia (Da Motta, Apresentação de Problematização do sujeito: psicologia, psiquiatria e psicanálise, 1999, p. VII).
}

Para Foucault, a psicanálise aparece como um saber contemporâneo que abre um novo espaço (teórico e prático), à medida que mostra que os processos inconscientes é que definem o psiquismo e não a consciência. Em Algumas Lições Elementares de Psicanálise, de 1938, Freud declara firmemente que a sua teoria nega o nivelamento entre o que é psíquico e o que é consciente, compreendendo a consciência como uma qualidade pouco freqüente do psíquico e, portanto, sendo este último, inconsciente em si mesmo. Assim, a definição do objeto da psicanálise (o inconsciente) traz consigo uma subversão das fronteiras disciplinares, pois está presente em todos os níveis dos fenômenos humanos. O grande impacto da psicanálise freudiana foi de questionar radicalmente a filosofia do "sujeito pensante" ou 
da consciência. Em Foucault, portanto, trata-se de uma oposição à tradição que identifica o cogito e o sujeito contra o inconsciente.

Intermediando a relação do homem com o mundo e a representação que tem de si mesmo, as leis do psiquismo atravessam também os "Homens da Ciência”. Trata-se, portanto, de uma incerteza, a qual os cientistas pouco têm se submetido, caso contrário, traria uma transformação profunda da própria cultura científica.

Em suma, do ponto de vista daqueles que não pretendem defender a cientificidade da psicanálise, esta não se encontra no conjunto das ciências naturais, tampouco no das ciências humanas, mas seu estatuto de contraciência repousa na questão que a construção psicanalítica evidencia que: "o homem da ciência não existe", o homem, em sua amplitude, só pode ser pensado a partir da teoria do sujeito. A noção de homem, das ciências humanas, está atrelada a uma cultura e se submete a um método, enquanto a noção de sujeito é universal. No entanto, para que a ciência conserve seu caráter de comunicabilidade é necessário encobrir o sujeito implicado no conhecimento.

Partindo da afirmação do físico Marcelo Gleiser (1998), de que a característica reducionista do último século oferece conseqüências nefastas para o desenvolvimento científico, Jeferson Machado Pinto identifica a redução como uma imposição inerente à lógica científica:

... a eliminação do sujeito ou, mais precisamente, da causa do desejo do sujeito que o torna absolutamente singular (...) coerente com uma postura que visa entender o mundo pelo esvaziamento de suas qualidades sensíveis, mostrando, assim, um sujeito que se sustenta no próprio ato de pensamento, independente de quaisquer propriedades psicológicas ou atributos culturais particulares (Machado Pinto, 2000, p. 166).

Machado Pinto afirma uma dependência da psicanálise em relação à ciência, mas produzindo efeitos que vão em direção contrária a ela, na medida em que visa a produção de um saber autoral, o qual tem uma função de verdade para o sujeito em particular. Posição semelhante encontra-se no texto de Luciano Elia (in Alberti; Elia, 2000), segundo o qual, a psicanálise se relaciona com a ciência em termos de derivação e ultrapassagem, isto é, estabelece um corte, um rompimento discursivo que se verifica na posição 
da noção de sujeito em cada um dos dois campos. Para o autor, ao invés de se perguntar se a ciência poderia reconhecer a psicanálise, é essa última que coloca um problema à ciência: "precisamente a de ter reintroduzido o sujeito na cena discursiva em que a ciência, ao fundar-se, o situou e da qual, no mesmo golpe, o excluiu" (2000, p. 20). Retirado da condição de excluído, o sujeito da psicanálise só pode ser incluído - no saber teórico, na prática clínica, na atividade de pesquisa, etc. - como sujeito do inconsciente. "É portanto insustentável que a psicanálise seja uma 'ciência humana', não se tratando, nela, de forma alguma, do 'homem' - sendo a própria noção de 'ciências humanas' o efeito da 'humanização' do sujeito constituído pela ciência moderna" (idem, p. 22).

Esse conjunto de proposições, que se caracteriza pela crítica dos efeitos dessubjetivantes da hegemonia do discurso científico, destaca o eixo de onde se percebe a especificidade da psicanálise: sua ética, definida por bem dizer a relação do sujeito com o desejo e com o gozo.

Diante do extenso panorama de referenciais de análise sobre o estatuto da teoria psicanalítica, que esta pesquisa apenas tangenciou, há de se reconhecer a impossibilidade de sobreposição das idéias que emergem daí. Poucos autores intervêm apenas para fortalecer os argumentos já existentes, mas, principalmente, apresentam novos posicionamentos, evidenciam fragilidades e colocam a problemática da cientificidade da psicanálise sob um novo prisma.

Como psicanalistas, concordam numa idéia essencial: para além de uma determinação fisiológica, química ou biológica, o homem é portador de um inconsciente concebido em termos de universalidade e singularidade. Como define Roudinesco (2000), o sujeito freudiano é dotado de uma razão que vacila no interior de si mesma.

Sem dúvida que toda dedicação em torno da formulação do inconsciente, desde as primeiras pesquisas de Freud, trouxeram inteligibilidade ao que durante muito tempo teve como campo mais próximo as ciências ocultas. Freud apresenta à comunidade científica a possibilidade 
de se descrever em leis os processos psíquicos, a partir de uma postura de sustentação crescente da dúvida.

Como já foi colocado, ultrapassa os objetivos deste trabalho analisar se os que são a favor de um debate em prol do reconhecimento científico da psicanálise estão mais bem fundamentados ou não em relação aos que argumentam a psicanálise como contraciência ou como portadora de outro estatuto. Inclusive, alguns autores, como Joel Birman (1994), percebem esse debate como ocupando um lugar secundário nos campos da filosofia e da psicanálise e prevêem seu silenciamento. Enquanto outros, como Luiz Alberto Hanns (2000), alertam para o fato de que cabe ao campo da psicologia dinâmica, onde se localiza a psicanálise, apresentar alternativas de aferição acessíveis e metodologicamente aceitáveis aos órgãos de saúde, universidades, centros de pesquisa e consumidores que demandam esclarecimentos, sob o risco de que a atividade clínica seja rebaixada para o status de terapia inócua, ineficaz, colocada na ilegalidade, na qualidade de charlatanismo. Realidade possível, segundo o autor, a partir da formalização de um corpo doutrinário que agregue diversas teorias e práticas psicoterapêuticas.

\footnotetext{
Este “corpo doutrinário”, apesar das diferentes linguagens e divergências entre as escolas, pressupõe que estas possuem elementos em comum, e que é possível formalizar estes elementos numa linguagem científica acessível a todos. Ele começa a emergir nos programas de ensino nas universidades principalmente anglo-saxônicas onde cada vez mais se organizam as disciplinas tematicamente integrando num mesmo eixo temático as abordagens diversas, por exemplo, psicologia da mulher, psicologia do envelhecimento, etc. (2000, p. 190).
}

Hanns avança suas críticas em direção às duas posturas descritas no início do presente capítulo, a saber: a indiferença pela pressão normativa que mantém os psicanalistas afastados das universidades e instituições governamentais; e a argumentação anti-normativista a partir de argumentos epistemológicos (como se supõe no texto de Monzani e nos textos dos defensores da psicanálise como contraciência). A hesitação dos psicanalistas é vista pelo conjunto de autores que Hanns qualifica como desprovidos de auto-crítica, impedindo uma compreensão mais consistente de seus princípios metodológicos e epistemológicos mais fundamentais. 
$E$ É freqüente que então se refugiem num discurso defensivo de relativizar a ciência, ou busquem abrigo na arte, ou que tentem criar uma epistemologia exclusiva, imaginando que se participarem do jogo científico terão de abdicar da especificidade de suas práticas (2000, p. 183).

São notórias a extensão e a profundidade da reflexão proposta em cada texto ou debate que permanece alimentando a polêmica entre psicanálise e ciência. É necessário reconhecer, portanto, que a questão da cientificidade da psicanálise torna seu objeto cada vez mais evidente tanto para a comunidade científica quanto para os próprios psicanalistas que buscam, incansavelmente, explicações sobre ele.

O respeito e a admiração dirigidos aos epistemólogos mencionados nos últimos parágrafos não se repetem quando a discussão sobre os critérios de cientificidade provém do tratamento dispensado por vários cientistas norte-americanos. Os defensores da cientificidade da psicanálise e os defensores da psicanálise como contraciência observam que a exigência behaviorista na compreensão do comportamento humano atingiu a psicanálise norte-americana, distorcendo conceitos e impondo critérios pouco fundamentados.

\section{O empirismo ${ }^{25}$ lógico e os "psicanalistas do comportamento" nos EUA}

Alcançando várias tradições culturais do Ocidente, a psicanálise sofreu os efeitos dos diferentes paradigmas sociais na medida em que foi recebida e interpretada durante sua expansão e difusão. Assim, como mostra Birman (1994), é possível perceber uma distância razoável entre a maneira como a psicanálise foi incorporada nos Estados Unidos e na França. Segundo o autor, enquanto na França buscou-se, sistematicamente,

\footnotetext{
25 “Empirismo é o nome genérico de todas as doutrinas filosóficas que negam a existÊncia de axiomas enquanto princípios de conhecimento logicamente distintos da experiência." Axioma, num sentido mais usual: "premissa considerada sem demonstração por todos os que lhe compreendem o sentido. '(...) Ela não tem necessidade de ser demonstrada: ... é um princípio... demasiado evidente para que seja preciso parar para considerá-lo’ (Lévy-Bruhl)” (Lalande, 1999, p.300 e 119-120).
} 
fundamentar uma leitura da teoria freudiana como uma ciência da cultura, como interpretação (portanto, no campo hermenêutico), tal como se destacam nas referências a Foucault e Lacan, nos Estados Unidos, procurou-se efetuar uma leitura neopositivista de cientificidade sobre a Psicanálise.

Heinz Hartmann, Marianne Kris e Rudolph Loewenstein ${ }^{26}$, europeus que migraram para os Estados Unidos, desenvolveram a chamada "psicologia do ego", projeto que se apoiava num modelo epistemológico da cientificidade natural e que foi considerado como a mais importante tentativa de que a psicanálise se constituísse numa teoria científica. Todavia, inseria a psicanálise no campo da psicologia, como uma teoria adaptativa do organismo com o meio ambiente.

Tendo Hartmann como precursor, a partir de 1937, a Ego Psychology foi constituída a partir da concepção desenvolvimentista do ego:

... centrada no crescimento e no amadurecimento conseqüente de suas funções adaptativas às exigências diversificadas do meio ambiente. No campo teórico assim delineado, foi possível representar a existência de um ego livre de conflitos, não marcado pela incidência do narcisismo e da sexuação, denominado de região autônoma do ego (Birman, 1994, p. 59).

Para apresentar a psicanálise como uma teoria operacional verificável e testada empiricamente, foi necessário transformá-la, inclusive, excluindoIhe determinados conceitos (como o da pulsão de morte). Assim, diversos autores percebem que, junto com a psicologia, a psicanálise norteamericana, passou a se configurar em métodos não-diretivos de psicoterapia, em mera técnica de integração / adaptação.

\footnotetext{
Ao que se acrescenta uma forma mental muito autóctone que sob o nome de behaviorismo, domina de tal modo a noção psicológica na América, que está claro que recobriu a partir de então completamente na psicanálise a inspiração freudiana. (...) Aparece em todo caso de maneira incontestável que a concepção de psicanálise aí se curvou em direção à adaptação do indivíduo ao meio social... (Lacan, 1978, p. 110).
}

Ao pretender guiar-se pela racionalidade científica, alicerçada no ideal 
de objetividade e para corresponder aos critérios de cientificidade basicamente pautados no empirismo lógico, a psicanálise deveria preocuparse com a lógica da explicação, caracterizada pela validação empírica. O que significa tornar a sua teoria passível de controle experimental e permitir que, através de procedimentos objetivos, pesquisadores independentes decidam em caso de interpretações opostas sobre os fenômenos psíquicos. Finalmente, para atingir os critérios que se colocam, exige-se que o método da interpretação dê lugar a previsões verificáveis. Em última instância, a psicanálise deveria pretender, tal como o behaviorismo, a definição de meios para determinados fins (uma ciência instrumental).

A "Psicologia do Ego" produziu uma deformação sistemática do pensamento freudiano e, acreditando eliminar a "falsidade" da teoria, estabeleceu alianças com escolas opostas à psicanálise. Um acidente mais apropriado a um fanatismo cientificista do que produto de uma criteriosa análise da Filosofia da Ciência.

Nesse ínterim, talvez se faça necessário uma distinção entre, por um lado, o trabalho crítico da Filosofia da Ciência, fundamentado em importantes construções teóricas que enriquecem o debate sobre a verdade e, por outro lado, um fanatismo conhecido pelo neologismo "cientificismo" que vem representar uma qualidade pejorativa de um uso específico do fazer ciência, assim definido por Roudinesco:

... o cientificismo acompanha incessantemente o discurso da ciência e a evolução das ciências na pretensão de resolver todos os problemas humanos por uma crença na determinação absoluta da capacidade que tem A Ciência de resolvê-los. (2000, p. 60)

Em poucas palavras, no âmbito da fundamentação ou das motivações, percebe-se uma importante distinção entre o "espírito científico" e o "cientificismo".

$\mathrm{Na}$ França, o cientificismo tomou uma proporção minoritária. Mas, em território norte-americano, o cientificismo parece pretender buscar a

\footnotetext{
${ }^{26}$ Sobre os três autores mencionados, é possível conhecer sua procedência e um resumo de seu trabalhos no Dicionário de Psicanálise, de Elisabeth Roudinesco e Michel Plon, 1998, respectivamente nas páginas 327-8, 443-1 e 477-8.
} 
legitimação de uma defesa contra o "contágio da psicanálise" ${ }^{27}$ ou, como disse o Prêmio Nobel Gerald Edelman, a uma resistência dos cientistas a seu próprio inconsciente. Segundo Roudinesco: “... nos países puritanos, sobretudo no Canadá e nos Estados Unidos, ela [a psicanálise] foi designada como uma doutrina satânica" (idem, p. 77). Como se sabe, antes de dirigir-se à América, em 1909, Freud já receava a recepção de sua teoria pelo "puritanismo do novo continente", e, inicialmente, esta foi, de fato, acusada de doutrina pansexualista.

Atualmente, os Estados Unidos destacam-se no volume de críticas dirigidas à psicanálise, tanto na questão da sua cientificidade, quanto na questão da sua eficiência terapêutica. Para tratar dos valores embutidos na atual visão norte-americana sobre o lugar epistemológico e técnico da psicanálise, deve-se compreender um contexto cultural muito amplo que, neste trabalho, apenas terá isolado alguns de seus elementos como o foco de atenção.

Em Por que a Psicanálise?, Elisabeth Roudinesco (2000) se dedica amplamente à evolução sociocultural que tem apresentado a psicanálise com um caráter envelhecido, ultrapassado e ineficaz. Tal evolução não se restringe ao contexto norte-americano, apesar de aí ser marcante, mas se estende por boa parte da cultura ocidental. Alguns aspectos parecem se destacar nesse cenário: a concepção de indivíduo a partir de uma democracia capitalista; o desenvolvimento da indústria psicofarmacológica; a popularidade das ciências cognitivas ${ }^{28}$; e a proliferação das psicoterapias.

Sobre o homem na cultura ocidental, Roudinesco o apresenta como o contrário de um sujeito. A democracia capitalista, modelo político-econômico que rege boa parte da cultura mundial, intervém nas relações entre os homens com a valorização de uma competitividade baseada unicamente no sucesso material. A definição de sucesso, calcada no poder de consumo, concretiza-se na figura do cidadão feliz. Uma felicidade vendida sob diversas formas deixa de ser uma aspiração e passa a representar uma exigência.

\footnotetext{
${ }^{27}$ Lembrando a expressão de Freud quando, em 1910, visita a América: "Mal sabem eles que estamos trazendo a peste."

28 "Surgida nos Estados Unidos por volta de 1950, à 'ciência' cognitiva atribuiu-se prontamente a tarefa de descrever as disposições e capacidades da mente humana (cognição), tais como a linguagem, a percepção, o raciocínio, a coordenação motora e o planejamento" (Roudinesco, 2000, p. 79).
} 
Disso decorre a impossibilidade do homem falar de seus sofrimentos íntimos e o silêncio passa então a ser preferível à linguagem, fonte de angústia e vergonha. Vendo-o atender ao imperativo e reivindicar um espaço dentro da norma (associando-se a grupos e a comunidades), a modernidade tende a abolir no homem o desejo de liberdade e, dentre tantas perdas, ele não tem tempo para nada (Roudinesco, 2000). Em 1921, Freud oferece uma justificativa ao "estilo" norte-americano de viver: "a concorrência é muito mais aguda entre eles, não ter êxito significa a morte civil para cada um deles, (...). E êxito significa dinheiro. Pode um americano viver em oposição à opinião pública, tal como estamos preparados para isso?" (Gay, 1989, p. 514).

Uma sociedade, de homens supostamente livres, felizes e adaptados às velozes inovações da modernidade, é surpreendida pelo medo ${ }^{29} \mathrm{da}$ desordem e da infelicidade. Cenário propício para o desenvolvimento da indústria psicofarmacológica, que oferece o consumo (no sentido mesmo de fazer desaparecer) quase instantâneo do afeto vergonhoso; propício também ao cientificismo, crente na resolução de todos os problemas humanos, às ciências cognitivas e à proliferação de todo tipo de psicoterapia.

Sem desconsiderar a percepção de uma tendência praticamente mundial e como bem expõem historiadores do nível de Gilberto Freire, observa-se que o brasileiro, muito mais do que receber influências estrangeiras, realiza rápidas incorporações culturais, fascinado pelo produto importado, em sua maioria, inovações tecnológicas, que essencialmente prometem antecipações em relação ao futuro, um suposto controle e conseqüente proteção contra o atraso, a exclusão, o descompasso, o sentirse diferente ao modelo imposto, o que significaria quase uma sentença de

\footnotetext{
${ }^{29}$ Em 2003, Michael Moore recebeu o prêmio Oscar por seu documentário, como diretor de Tiros em Columbine. Toma o exemplo do atentado em Denver (Colorado), em que um grupo de adolescentes, caracterizados nos personagens da série Matrix, irrompe pelas portas de sua escola portando armas que usam para matar professores e colegas. O tema principal desse documentário é desvendar a razão pela qual parece ser tão fácil a um norte-americano disparar sua arma contra uma pessoa. Reunindo acontecimentos recentes e aspectos da história dos Estados Unidos, Michael Moore revela o medo como elementar em sua cultura. Moore conduz seu público a perceber que a violência é a manifestação de uma organização paranóica da cultura norte-americana. Uma reflexão psicanalítica acerca da função paterna na cultura americana pareceria resultar num instigante trabalho que, no entanto, extrapola os limites deste. Cabe apenas acrescentar a análise que Freud sobre o medo dos norte-americanos em relação à sexualidade e de uma retenção sádico-anal avessa ao prazer, que,
} 
morte. Em suma, a fonte cultural onde boa parte do mundo, inclusive o Brasil, procura referências para seu desenvolvimento obedece à lógica de que tudo deve corroborar com sua ideologia da felicidade. O preço disso é uma cegueira em relação a qualquer teoria da subjetividade, erradicando as paixões, o sofrimento, o sujeito, a linguagem, a história, em suma, o desejo, no âmbito da clínica e da reflexão universitária.

Alguns aspectos da cultura norte-americana já tinham sofrido pesadas críticas de Freud. Mais do que isso, em sua biografia redigida por Peter Gay, encontram-se expressões claras de seu anti-americanismo, que Gay interpreta como uma "encarnação" do inimigo que Freud assumidamente sempre precisou ter. Considerava os EUA e seus habitantes, hipócritas, incultos, superficiais, interessados apenas em dinheiro e veladamente antisemitas. E, apesar das boas perspectivas para a expansão da causa, em ocasião do convite do reitor da Clark University (Stanley Hall), os Estados Unidos, segundo Freud, foram responsáveis por uma disfunção intestinal e uma "paralisia em escrever" sofridas por ele. A cada viagem de seus adeptos aos EUA, Freud temia o abandono da causa.

Adversários da análise leiga, as pretensões dos norte-americanos

... realmente me parecem ir longe demais e excessivamente ditadas por interesses estreitos e egoístas.(...) eles colocam seus interesses de status acima da comunidade analítica e não vão enxergar os perigos a que expõem o futuro da análise. (Idem, 1989, p. 453-4)

Restrita aos doutores em medicina, a análise estaria demasiadamente envolvida em pesquisas orgânicas, em detrimento das pesquisas psicológicas. Em suma, para Freud, tratava-se de uma nação gigantesca que levava seus seguidores a enganos de proporções também gigantescas. Assim, tinha a impressão de que "a análise combina com os americanos assim como uma camisa branca combina com um corvo" (ibid., 1989, p. 510). 


\section{Naturwissenschften: entre o desejo pela cientificidade e a natureza do objeto}

Freud desempenhou todas as funções que hoje continuam centrais no meio universitário: como pesquisador, desenvolveu experimentos em laboratórios de destaque em produções científicas; publicou trabalhos no campo da neurologia; e, como professor, ministrou cursos e conferências. Reconheceu a importância de seus mestres, aos quais permaneceu fiel, mesmo quando iniciou sua polêmica investigação sobre o psiquismo. Viveu a época e o lugar de efervescência das discussões acerca da ciência, seus princípios, descobertas e sua promessa (presente ainda hoje) de resolução de todos os males do mundo. "Como a 'cientificidade' era altamente cotada na bolsa de valores culturais da época de Freud, era natural que ele procurasse a glória, não nos caminhos da filosofia ou da literatura, mas nos caminhos da ciência" (Japiassu, 1998, p. 66). Freud pretendeu impor-se como homem de ciência, a partir do reconhecimento da psicanálise pela comunidade científica de sua época.

Nos cinqüenta anos que dedicou à psicanálise, Freud enfrentou constantes críticas de opositores, além de ameaças de distorções da teoria por alguns aprendizes (como Jung e Adler). No entanto, o maior conflito talvez tenha ocorrido no âmbito interior. Provenientes de diferentes textos, destacam-se algumas passagens em que Freud manifesta sua decepção em não ver a psicanálise reconhecida como ciência. Em Algumas Lições Elementares de Psicanálise, publicado em 1938, um ano antes de sua morte, Freud compara a dificuldade que encontra para definir a natureza do psíquico com a situação do físico diante da natureza da eletricidade. Diz ele que: "a psicanálise constitui uma parte da ciência ${ }^{30}$ mental da psicologia"; que "também a psicologia é uma ciência natural'; e que a psicanálise adere à visão científica do mundo.

Durante toda sua vida, mesmo combatendo as críticas dos que duvidavam do mérito científico da psicanálise, Freud permaneceu convicto 
no aspecto da ciência que representa a perfeita visão da verdade e, por conseguinte, a integridade intelectual. Por isso, no início de sua vida profissional, percebe-se que o uso livre e audacioso da imaginação que lhe era peculiar cedeu lugar ao trabalho disciplinado e metódico da investigação científica, traço que sentia faltar em si mesmo. Equivocadamente atribuído a Goethe, o ensaio Sobre a Natureza, que Freud conheceu numa conferência de Carl Bernhard Brühl, é considerado responsável por seu interesse em tornar-se cientista natural, abandonando sua aspiração pelo direito. Mesmo assim, para além das exigências do curso de medicina, freqüentou as aulas de leitura de filosofia de Franz Brentano, especialmente sobre a lógica de Aristóteles.

Ainda como estudante e no início de sua vida profissional, trabalhou no Laboratório de Fisiologia de Ernst Brücke, homem que Freud admirou pela autoridade que representava e como disciplinado cientista. Parte de um abrangente movimento científico conhecido como Escola de Medicina de Helmholtz, o laboratório onde Freud trabalhou desde que completara o terceiro ano do curso de medicina esteve sempre impulsionado pelo juramento de seus fundadores, Brücke e Du Bois, datado de 1842:

\footnotetext{
Nenhumas outras forças, a não ser as físico-químicas comuns, acham-se em ação ativa no interior do organismo. Nos casos em que não se possam obter informações através dessas forças, eventualmente, ter-se-á de encontrar um caminho específico ou a forma de sua ação por intermédio do método físico-matemático ou admitir novas forças, idênticas em dignidade às forças químico-físicas inerentes à matéria, e que são redutíveis à força de atração e repulsão. (Apud Jones, 1979, p. 73)
}

Partindo das noções de força e quantidade, os fenômenos orgânicos eram aí concebidos pelo modelo de regulação do sistema nervoso, segundo o qual a energia proveniente do meio exterior é descarregada pela ação do sistema muscular (Lo Bianco, 2002).

Freud dedicou-se ao estudo da estrutura gonádica das enguias e, por orientação de Brücke ${ }^{31}$, passou para a investigação da histologia das células

\footnotetext{
31 “Exner era assistente de Brücke no Laboratório de Fisiologia e Freud era um dos pesquisadores, sob a orientação de Brücke, sendo também discípulo de Exner (Jones, 1980). O trabalho dava-se em circunstâncias tais que, por estarem ambos, Exner e Freud, sob a orientação de Brücke, tinham grande amizade um pelo outro e se dedicavam a um conjunto de idéias muito semelhantes" (Lo Bianco, 2002, p. 152)
} 
nervosas, estudo que permitiu deparar-se com a natureza da diferenciação entre a constituição cerebral dos animais inferiores com a do homem. Experimentou o confronto entre os fundamentos biológicos e as implicações filosóficas e religiosas que fundamentam as disposições do ser humano.

Habituado com as dificuldades impostas ao progresso do conhecimento, Freud desenvolveu novos métodos e instrumentos, como exemplo, criou uma nova fórmula para preparação do tecido nervoso a ser pesquisado. A experiência como cientista de laboratório promoveu a compreensão de que a teoria pode anteceder a especulação e uma compreensão de realidades nem sempre acessíveis pela observação.

No Instituto de Fisiologia, nos últimos anos da década de setenta (do século XIX), Freud conheceu Breuer, outro fiel seguidor da escola de Helmholtz que em 1880 passa a tratar de Anna O.. Nesse clássico caso, que praticamente funda a psicanálise, a histeria se apresenta numa nova perspectiva: qualquer que fosse a base neurológica, Anna O. evidenciou que os sintomas da histeria poderiam ser tratados e extintos pelo "mero" emprego de palavras. Desde aí, compreendeu que as associações de idéias, aparentemente desconexas, acidentais, inarticuladas e sem sentido, na verdade, tinham seu curso determinado por alguma instância "concreta". Isto se confirmava quando, na emergência de uma lembrança, uma cadeia de idéias precedentes tinha seu sentido revelado. Passando do emprego da hipnose ao método da associação-livre, Freud se manteve atento ao percurso do pensamento de seus pacientes.

Dos princípios centrados nas concepções científicas helmholtzianas, permanecia, em paralelo, o antigo problema das relações entre corpo e mente e uma aspiração pela descoberta de uma base fisiológica que explicasse o funcionamento mental. Isto fica evidente no texto de 1895, Projeto de uma Psicologia Científica:

O propósito [é] fornecer uma psicologia científico-naturalista, ou seja, apresentar processos psíquicos como estados quantitativamente determinados de partes materiais capazes de ser especificadas e, com isso, torná-los intuitivos e livres de contradição. [Estão] contidas duas idéias principais: 1) concebe o que diferencia atividade de repouso como $Q$, submetida à lei geral do movimento; 2) toma os neurônios como partículas materiais. (Freud, 1995, p. 9) 
Esse modelo teórico pretende explicar o funcionamento do psiquismo, baseando-se nas propriedades dos neurônios. Assim, considera a percepção como um conjunto de representações conscientes, sob a forma de força material localizada no neurônio, da qual uma parte é retida pelo neurônio, formando a memória. Aspectos qualitativos, como a percepção, a sensação e a memória, são concebidos como quantitativos, isto é, um jogo de quantidades que se movimentam (fluxo) com uma direção e passível de retenção. Em suma, cada conceito supostamente abstrato teria um correspondente material, integrado ao sistema nervoso central.

\footnotetext{
O que nos é apresentado com essas palavras [de Fechner] é a idéia de uma localização psíquica. Desprezarei por completo o fato de que o aparelho anímico em que estamos aqui interessados é-nos também conhecido sob a forma de uma preparação anatômica e evitarei cuidadosamente a tentação de determinar essa localização psíquica como se fosse anatômica. Permanecerei no campo psicológico... (Freud, [1900] 1988, p. 566-7)
}

Mesmo acompanhado das referências no determinismo, na causalidade, na exatidão, na disciplina, no positivismo científico, Freud identifica o momento de entregar-se irrestritamente ao exercício do pensamento, ao jogo da fantasia, dando margem às idéias de livre-arbítrio, finalidade, intenção e alvo. O próprio método da associação-livre tratava-se de um "deslocamento de uma pesquisa sistemática e orientada por um objetivo conhecido para uma oscilação cega e descontrolada" (Jones, 1979, p. 254).

Alguns autores consideram que, durante os anos de 1888 e 1889, Freud enfrentou internamente uma exigente luta, até libertar-se da idéia de correlacionar a atividade somática e psíquica. Identificam esse momento como a primeira expressão da psicanálise, com destaque ao texto de 1900, sobre $A$ Interpretação de Sonhos, como é possível perceber na citação acima. Assim, segundo esses autores, há dois tempos bem definidos no desenvolvimento da obra freudiana: o primeiro, de busca irrestrita pelos referenciais biológicos para respaldar a compreensão do funcionamento psíquico; o segundo, quando Freud teria abandonado, enfim, as amarras da herança da formação em medicina e, enfim, possibilitado emergir resultados mais fecundos em sua produção teórica. 
A partir de outra leitura das obras, pode-se verificar que Freud "sempre foi atormentado pela tentação de uma 'naturalização' da ciência do psiquismo" (Roudinesco, 2000, p. 64). Aspecto que pode ser verificado em suas correspondências com Fliess, entre 1887 e 1902, quando manifestava o desejo de que, finalmente, as bases fisiológicas viessem se sobrepor às bases psicológicas de sua teoria das neuroses e no já citado texto de 1938 , Algumas Lições Elementares de Psicanálise.

Lo Bianco observa que, se é possível identificar um abandono do pensamento científico no segundo momento dos textos freudianos, as marcas das idéias da época reaparecem em todo trabalho subseqüente. Sem dúvida que houve uma mudança significativa num sentido adverso dos estudos aos quais Freud se dedicava, no entanto, a autora explica tal separação como "um novo trabalho que se destaca do meio que o gerou (ou no qual foi gerado)" (2002, p. 155).

No posfácio do texto Fragmento de Análise de um caso de Histeria, de 1905, encontra-se uma defesa às supostas acusações de que a teoria das neuroses se limitasse a uma teoria psicológica, portanto, incapaz de solucionar um problema patológico. Nele, Freud esclarece que apenas a técnica terapêutica é puramente psicológica, mas que a sua teoria não deixa de apontar para as bases orgânicas da neurose. Nos Três Ensaios sobre a Teoria da Sexualidade, publicado também em 1905, baseando-se nas experiências com gônadas de animais, Freud afirma ter parcialmente esclarecido a questão da excitação sexual, por conseguinte, a ativação da anomalia sexual presente na origem de todas as neuroses. Apresenta uma distinção entre a excitação proveniente da estimulação das zonas erógenas e das provenientes de uma intoxicação por substâncias estranhas ao organismo (os alcalóides). Em Um Estudo Autobiográfico, de 1924, Freud reafirma a tese, já apresentada em 1905, da existência de dois tipos básicos de neurose: as neuroses de angústia, caracterizadas por manifestações mentais; e as neuroses atuais, caracterizadas por manifestações somáticas. As últimas comprovariam que os processos que determinam no organismo a formação e a utilização da libido sexual são, em última análise, de natureza química. 
Se hoje lanço um olhar retrospectivo aos meus primeiros achados, eles me surpreendem como sendo os primeiros delineamentos toscos daquilo que é provavelmente um assunto muito mais complicado. Mas no todo ainda me parecem válidos. (...) estou longe de negar a existência de conflitos mentais e de complexos neuróticos na neurastenia. Tudo o que estou afirmando é que os sintomas desses pacientes não são mentalmente determinados ou removíveis pela análise, mas devem ser considerados como conseqüências tóxicas diretas de processos químicos sexuais perturbados. (Freud, [1924] 1988, p. 32)

Em 1932, Freud ainda permanecia queixoso da incompreensão dos representantes da ciência oficial. Acusava-os de violação da lógica, da propriedade e do bom gosto para elaborarem argumentos preconceituosos em relação à jovem análise. Reconhecia a origem da resistência à psicanálise como a mesma que enfrentava no trabalho clínico: as representações mentais que constituem ameaças à estabilidade psíquica do sujeito são recalcadas e suprimidas da vida mental consciente. A dificuldade de reconhecimento e a tendência à rejeição da psicanálise são características inerentes ao saber que a teoria revela: essencialmente, de que nossas primeiras motivações não obedecem à racionalidade, de que não somos soberanos em nós mesmos. Conseqüentemente, a medicina seria levada a reconhecer sofrimentos que não provém do orgânico e a filosofia, um saber que não habita a consciência.

Essa capacidade de compreensão da oposição de cientistas a partir das premissas psicanalíticas já tinha sido demonstrada em 1914 em $A$ História do Movimento Psicanalítico e em 1924, no texto As Resistências à Psicanálise. "Diagnóstico" que evidenciava um impasse na discussão acerca da cientificidade da teoria freudiana: a resistência dos cientistas à Psicanálise está tão fora da consciência quanto a resistência dos pacientes em recordar. Em suma, Freud tratou a resistência de seus opositores como expressão da angústia desencadeada por uma percepção que exige reestruturação do campo afetivo, portanto, uma resistência de natureza emocional.

Em resposta ao repúdio da ciência oficial e ao boicote aos médicos e instituições praticantes da psicanálise, foi fundada a Associação 
Psicanalítica Internacional, a fim de evitar distorções da prática, promover a troca de idéias e o apoio mútuo entre os partidários. Dessa forma, foi declarado que o objetivo central da associação "era 'promover e apoiar a ciência da psicanálise fundada por Freud, tanto como psicologia pura como em sua aplicação à medicina e às ciências mentais (...)"' (Freud, [1914] 1988, p. 53).

Não há dúvidas de que Freud e psicanalistas contemporâneos seus nomeavam a psicanálise como ciência, uma ciência psicológica, porém, distinta da psicologia que se desenvolvia nos Estados Unidos. Apesar de utilizar o termo "psicologia" em sua obra, pensa-o sempre sob a forma de uma teoria do inconsciente, não como comportamentos (conscientes), tampouco como possuindo a função de proporcionar alívio imediato e controle da angústia característica do desconhecimento do homem sobre sua própria existência. Ao invés de tratar o sintoma, a psicanálise o traduz.

Conforme o exposto até o momento, é possível constatar duas idéias que freqüentam permanentemente $o$ trabalho de Freud: o reconhecimento da natureza não empírica do seu principal objeto de pesquisa, o inconsciente (Freud o compara com o objeto da física); e, por outro lado, a aspiração por encontrar bases orgânicas que fundamentassem o que sua teoria indica como o fator central na formação do psiquismo, a sexualidade. Portanto, ansiava o reconhecimento científico e o buscava através das bases biológicas, representadas pela química, pelos neurônios ou, ainda, pelos instintos. Parece terem Ihe faltado os elementos que o levaria a realizar sua aspiração, apoiando-se, prioritariamente, no objeto da psicanálise. Essa dificuldade é o que caracteriza o desafio daqueles que, ainda hoje, buscam o reconhecimento científico da teoria psicanalítica.

Se no início de sua empreitada o argumento neurológico não the foi favorável, Freud sempre percebeu a consistência de outro argumento: transitando por entre métodos, critérios e contestações, a psicanálise, tal como as outras ciências, opõe-se à certeza religiosa. Tema amplamente abordado em O Futuro de uma llusão, de 1927, mas cuja polêmica retoma a pergunta: os "Homens da Ciência" estariam menos suscetíveis às ilusões do que os teólogos? Em ocasião da publicação do texto, Freud mantinha sua correspondência com o pastor protestante Oskar Pfister, portanto, um 
diálogo inquietante com a religião.

\begin{abstract}
De qualquer modo, a experiência "pura" é a meus olhos uma ficção, e quando revisamos a história das ciências vemos como a realidade contida na nossa assim chamada experiência é dúbia. E também essa mistura de ilusão e verdade a que chamamos de "experiência", nós só a obtemos com a ajuda de pressuposições transempíricas. Conceitos como causa, atmosfera, átomo etc. certamente estão saturados de contradições mais grosseiras que aqueles dos teólogos, e o senhor sabe melhor do que eu como as leis da natureza encontram-se desmanteladas na física atual. 0 cientista só-empírico é aos meus olhos um non sens... (Oskar Pfister, carta de 24 de novembro de 1927).
\end{abstract}

Para iluminar um pouco mais a análise do contexto no qual transitam as bases do trabalho de Freud, algumas considerações sobre as influências da produção literária do movimento romântico, na passagem do século XVIII ao XIX, apontado por Lo Bianco (2002) como um universo que coloca as artes no centro das preocupações humanas, podem justificar o interesse de Freud pelo tema dos sonhos, do cotidiano, do desejo, da morte, do estranho e do inconsciente. Temas contra os quais se opunham as proposições da ciência objetiva.

A dimensão do "inexplicável", a referência ao misterioso e ao demoníaco no pensamento romântico, elementos cuja aproximação se daria por meio da introspecção e da intuição, traziam consigo a dimensão de interioridade. Lo Bianco estabelece paralelos entre a obra freudiana e as características desse cenário: no texto $A$ Interpretação de Sonhos, a espontaneidade, os sentidos, a intuição; o pensamento poético nas considerações sobre o desejo; a figurabilidade, o símbolo na lógica inconsciente; a singularidade na inserção do sujeito na cultura; e, finalmente, a dimensão inatingível e inesgotável do sujeito humano.

\title{
O discurso da universidade versus uma teoria fictícia
}

A polêmica em torno da cientificidade da psicanálise interessa especialmente à presente pesquisa, pois encerra uma segunda polêmica: a legitimidade, ou mesmo, a fertilidade de seu ensino. A impossibilidade de 
que o discurso psicanalítico seja veiculado pela linguagem científica, do ponto de vista de alguns teóricos, coloca em suspenso a validade de suas proposições, assim, passa-se a questionar a "transmissibilidade" do empreendimento epistemológico representado pela teoria psicanalítica (Dor, 1993).

É exatamente no objeto da psicanálise que repousam as bases da questão da cientificidade e, conseqüentemente, da transmissão: em primeiro lugar, o inconsciente se interpõe na relação do sujeito com o conhecimento, redimensionado as noções de verdade e de certeza; em segundo lugar, o inconsciente emerge no ato da transmissão, opondo as noções de saber e de conhecimento, à medida que, implicado no desejo de "um a um", traduzse pelo fenômeno da transferência.

O discurso psicanalítico está subordinado à sua própria constatação: não existe transmissão sem transferência, o que invalida qualquer tentativa de transmissão da verdade, tal como ela se apresenta no discurso científico. A única verdade que a teoria psicanalítica se propõe afirmar é a verdade do inconsciente. Isso implica dizer que a tentativa de traduzir seu objeto numa linguagem científica significaria negá-lo. Por isso, a teoria psicanalítica se apresenta como uma teoria fictícia: a única verdade é aquela que escapa ao sujeito.

\footnotetext{
Se há algo que toda a nossa abordagem delimita, que seguramente foi renovado pela experiência analítica, é justamente que nenhuma evocação da verdade pode ser feita se não for para indicar que ela só é acessível por um semi-dizer, que ela não pode ser inteiramente dita porque, para além de sua metade, não há nada a dizer. Tudo o que se pode dizer é isto. Aqui, por conseguinte, o discurso se abole. Não se fala do indizível, por mais prazer que isto pareça dar a alguns (Lacan, [1969-1970] 1992, p. 49).
}

No discurso da ciência, o cientista, como diz Lacan (1992), é construído artificialmente, dotado de aparelhos (preconcepções, metodologias e equipamentos) e de um conjunto de órgãos vitais (os sensoriais são vitais à pesquisa), que o distinguem e o exclui da noção de sujeito dividido que a psicanálise revela.

Em outras palavras, a ilusão da objetividade na ciência se sustenta na exclusão do próprio sujeito da ciência. Em seu discurso não pode haver seus 
traços ou marcas. O saber, para o discurso científico, age no real (racional) e independente do sujeito que, por sua vez, é substância que pretensamente reflete o saber das coisas. "Neste contexto, a psicanálise recorta-se no horizonte do pensar moderno: há saber independente do sujeito" (Lajonquière, 1994, p. 63). O sujeito, para a psicanálise, utiliza-se da língua para dizer sem saber, isto é, seu dito está ligado a outros ditos no campo do Outro, portanto, sendo dito pelo campo do Outro, o que enuncia através da linguagem é sempre a metade de uma verdade.

Em A Arqueologia do Saber, Foucault, mais uma vez no eixo da interpretação, capacita uma perspectiva sobre a verdade, na compreensão da apropriação do saber e da legitimidade de uma obra. Pode-se começar pelo "negativo" de uma obra. Ela não pode ser considerada uma unidade imediata, nem como unidade certa, tampouco, homogênia, mas, constituída por uma operação interpretativa. Portanto, uma obra, como interpretação, "decifra, no texto, a transcendência de alguma coisa que ele esconde e manifesta ao mesmo tempo" (2004, p. 27).

Reconhecendo que sua análise possa estar situada num campo distinto da epistemologia e da história das ciências, Foucault parte da análise do discurso que designa por presunção de racionalidade científica. Coloca para si o seguinte desafio: saber o que tornou possíveis certos domínios e como determinadas "descobertas" puderam ser seguidas de outras, que as retomaram, corrigiram, modificaram ou anularam. Destaca, a partir daí, o papel das circunstâncias e condições históricas como responsáveis pelo aparecimento de objetos que guardam relações de semelhança: "Isto significa que não se pode falar de qualquer coisa em qualquer época (...) o objeto não espera nos limbos a ordem que vai liberá-lo e permitir-lhe que se encarne em uma visível e eloquaz objetividade" (idem, p. 50) ${ }^{32}$. Portanto, não basta abrir os olhos, prestar atenção, "tomar consciência" para que os objetos se evidenciem. Eles não preexistem a si mesmos, mas estão condicionados a um feixe complexo de relações discursivas (estabelecidas entre instituições, processos econômicos, sociais,

\footnotetext{
${ }^{32}$ Cabe assinalar que tal concepção foucaultiana é desacreditada por Laplanche, que a qualifica de um insustentável idealismo historicista. Como se pode verificar em Problemáticas IV, Referência ao Inconsciente, 1992, p. 3.
} 
comportamentos, sistemas de normas, classificações...) que caracterizam circunstâncias históricas.

Assim, o discurso que formaliza uma obra deixa de ser compreendido como um conjunto de signos, para constituir "práticas que formam sistematicamente os objetos de que falam" (ibid., p. 55). O discurso faz mais do que utilizar signos para designar coisas. Irredutível à língua e ao ato da fala, "esse 'mais' que é preciso fazer aparecer e que é preciso descrever" (Ibid., p. 55).

O discurso não é realidade a ser interpretada em seu sentido, mas sim o efeito da cadeia significante. Deixando de pensar o discurso como uma tradução verbal do exterior, passa-se a pensá-lo como o próprio lugar de emergência dos conceitos, portanto, no limite, poderia se afirmar que é o discurso que cria o objeto. Não sendo mais uma tradução, também não se trata do produto da capacidade de pensar de um sujeito, que conhece o objeto e o diz, nem de sua subjetividade psicológica. A formação discursiva se compõe exterior à "mentalidade" ou consciência dos indivíduos e se impõe "anonimamente" a todos os que tentam falar nesse campo discursivo. "Esses discursos, não os escolhemos, eles nos escolhem e nos arrastam, para além de nossa vontade, do nosso 'querer dizer', falam-nos apesar de nós" (Rabinovich, 1991, p. 11).

Tomando como exemplo a teoria mesma que sustenta a análise proposta na presente tese - a psicanálise - é possível depreender, a partir do texto de Foucault que ao formar, numa determinada circunstância, as relações discursivas que representam a obra psicanalítica, seu objeto (o inconsciente) e derivações (sintomas, estruturas, economia, etc), é instituída uma determinada "ordem" no discurso social. Arma, por conseguinte, o dispositivo que produz a emergência de seu objeto. Produz o discurso e é produzida por ele, na medida em que põe os sujeitos a falar.

Como foi exposto anteriormente, aquilo que o sujeito diz está ligado a outros ditos que a psicanálise designa como sendo o campo do Outro. Assim, ao mesmo tempo em que diz, também é dito. Para Lacan, "...a 
referência de um discurso é aquilo que ele confessa querer dominar, querer amestrar" (1992, p. 65). A problemática que se pretende apresentar aqui pode ser traduzida nas diferenças entre os discursos. Apesar de complementares, o discurso da ciência e o discurso da universidade não são a mesma coisa. Enquanto o discurso da ciência pretende dominar a noção de verdade, o discurso da universidade, campo em que se privilegia a transmissão da mesma verdade, caracteriza-se pelo pretenso domínio perfeito da transmissão.

Portador de um saber coerente e estável, no discurso da universidade, o professor sabe o que diz. Portanto, o domínio da transmissão supõe a referência ao bem entendido. Os sujeitos que participam do ato da transmissão são tidos como em estado de controle (não divididos), o saber transmitido guarda sua identidade com a verdade (da ciência) e, finalmente, aquilo que se pronuncia atinge igualmente cada um do público, sem produzir dúvidas, furos, apenas certezas e garantias. Em síntese, o discurso da universidade pretende o domínio da transmissão da verdade às massas.

Em convergência com a leitura foucaultiana sobre a formação de redes discursivas, a psicanálise compreende o sujeito como em estado de divisão, quando fala, está desligado do imperativo de saber o que diz. Mais do que isso, no caso do educador, suposto portador de um saber constituído, é convidado a se excluir de saber dando passagem a uma verdade nascente. $O$ efeito dessa verdade toca um por um os sujeitos implicados na transmissão e, assim, a transmissão produz efeitos (faz ato).

Lacan recorre à estrutura representada pelo discurso do mestre para falar da transmissão: a legitimidade das posições e o lugar onde o saber repousa. O discurso do mestre, ou do senhor, é ilustrado na relação necessária para sustentar a dupla Senhor ${ }^{33}$ - Escravo. O segundo da dupla é quem sustenta a posição do primeiro, isto é, ele é caracterizado como o suporte do saber. A passagem desse saber para o lugar do senhor é que define o saber como todo-saber. A posição do escravo é que "permite que o

\footnotetext{
${ }^{33}$ Inspirado na fenomenologia de Hegel, da relação dialética entre o Senhor e o Escravo, esse senhor que serve de exemplo a Lacan é aquele antigo, dos tempos de Aristóteles, cujo escravo era uma
} 
saber se torne um saber de senhor" (1992, p. 19), quem tudo sabe. A verdade, portanto, como todo-saber, escapa aos dois, isto é, só é todo-saber na posição do senhor, ao passo que este não o sabe. Aliás, se soubesse, como o escravo o sabe (o savoir-faire), este também não existiria.

O saber não está num ou noutro, mas, esse "engano" é que se apresenta como o dispositivo que sustenta a dupla e permite que o saber se diga através da língua dos sujeitos em questão e seja "conhecido" pelas meias verdades produzidas aí: “...o saber é coisa que se diz, que é dita. Pois bem, o saber fala por conta própria - eis o inconsciente" (idem, p. 66). Lacan já o tinha escrito no Seminário 8, sobre a transferência, utilizando-se de outra estrutura, a do sujeito suposto saber, ilustrada na relação entre Sócrates e Alcibíades, para nos falar do "engano" que sustenta a suposição de saber no mestre. Sócrates, como o senhor na primeira dupla, se abstém desse lugar de tudo-saber. Posição que o mantém mestre, por saber-se inconscientemente sujeito à castração.

Como é possível ver, a transmissão, compreendida pela psicanálise, está mais próxima de um mal-entendido do que ao bem entendido que o discurso da universidade aspira. Encerrada por seu próprio objeto, a transmissão da teoria psicanalítica está condicionada à relação do sujeito com o conhecimento. $O$ desejo que caracteriza cada sujeito traduz a própria teoria a ser transmitida e, por isso, ela, uma ficção, é reinventada a cada vez. Pode-se dizer de um estilo nessa relação singular entre o sujeito que transmite com aquilo que pretende evocar. O discurso da universidade, por razões de estrutura (aspirando à coerência e à estabilidade), não concebe o saber habitado pelo desejo, por conseguinte, pretende um ensino para as massas, padronizado, em outras palavras, sem estilo.

Uma história real do século XII ilustra, em certa medida, as oposições que aqui são apresentadas: o saber de Pierre Abelardo $^{34}$ era habitado pelo

função (savoir-faire, saber fazer) inscrita na família. Não se trata, portanto, do moderno senhor capitalista, para quem o escravo é meio de consumo, modificando o lugar do saber.

${ }^{34}$ Pierre Abelardo (1079-1142), teólogo e filósofo francês, era professor de filosofia de Heloísa (11011164), sobrinha do cônego Fulbert. Quando o romance entre Abelardo e Heloísa foi descoberto, Fulbert decidiu mandar castrar Abelardo. Apesar de já casados (em sigilo) e com um filho, Abelardo torna-se monge em Saint-Denys e Heloísa torna-se abadessa do Paracleto (instituição fundada por Abelardo). Os antigos amantes se correspondem por cartas. Heloísa conserva seu amor por Abelardo, enquanto este se empenha num longo trabalho de interiorização. "O fato de Abelardo responder mostra que ele tem agora consciência de cumprir uma missão. Ele tem a tarefa de constranger Heloísa; 
desejo, por isso foi castrado para que pudesse "representar a verdade", assim, seu exemplo expõe a oposição compreendida no discurso universitário entre desejo e saber.

... tudo o que vive foi encerrado, pelo homem medieval, em quadros racionais e teóricos, e o que não entra num desses quadros não tem valor de cultura, permanece repugnante selvageria. As paixões do amor ficam à margem do universo conceptual, tanto mais vivazes, indomadas, mas ao mesmo tempo privadas de linguagem e dessa relativa segurança que vale a inserção numa ordem. (Zumthor, 2000, p. 8)

Sobretudo em Abelardo, a dialética da escolástica, o problema da relação entre a fé e razão, formaliza o pensamento e dá colorido ao sentimento. Revestido de desejo, seu discurso captura Heloísa. O desejo se expressa, no entanto, num cenário cultural submetido a uma tensão, à incompatibilidade entre "instinto" e "pensamento" que

\footnotetext{
...encobriam uma série de outras, misturadas: sensibilidade e vontade, real concreto e abstração dedutiva, política e teologia, economia e moral, poder criador e ciência teórica, e, bem no fundo, apesar de certas aparências, homem e Deus. (Idem, 2000, p. 7)
}

De filósofo e professor de filosofia, após sua castração (encomendada pelo tio de Heloísa), Abelardo passa a se dedicar à Igreja. Contudo, a religião não é de todo apaziguadora (não domina), pois seu amor por Heloísa permaneceu.

Dessa história se extrai algumas interpretações possíveis. $\mathrm{Na}$ presente pesquisa preferiu-se destacar a seguinte: na tentativa de extirpar o desejo, a "verdade" comunicada sem "estilo" se transformaria num dogma e não mais causaria efeitos. Por isso, foi preciso castrar Abelardo, como condição de não mais produzir efeitos com seu discurso.

Na transcendência do corpo, a religião "salva" (efeitos subjetivantes) o desejo de Abelardo.

de transformar nela esse amor e, ainda que ao preço de dores atrozes, fazer com que apareça sob o aspecto eterno" (Zumthor, 2000, p. 18). 
A análise apresentada neste texto está afastada da idéia de que a importância da psicanálise no campo epistemológico deva ser medida pela sua cientificidade. Assim, este segundo capítulo apresentou-se um útil respaldo para a crítica à determinada resistência à transmissão da psicanálise na universidade, bem como, redimensiona a confiança exacerbada que alimenta o discurso predominante na educação. Negar a contribuição do diálogo com a psicanálise significa rejeitar um redimensionamento das noções básicas para se pensar a educação.

A formação de educadores, compreendida principalmente no território universitário, parece ainda estar pautada numa pesquisa da verdade que respeita um ceticismo estéril criticado nas primeiras tentativas de contribuição da psicologia à pedagogia, desde Willian James e Claparède, como Cifali apresenta em texto de 1986. Conformando-se às medidas preconizadas pelo discurso universitário, a pedagogia aspira uma transmissão híbrida, originária do cruzamento de diversas produções científicas, da qual poderá presumir os resultados: uma transmissão sem efeitos, um projeto irrealizável que condena a educação a um imobilismo e a parcerias infrutíferas.

Enquanto os saberes pedagógicos são promovidos pelo discurso universitário, a educação que faz ato está sujeita ao discurso do mestre. A legitimidade da autoridade do educador reside no saber-se, inconscientemente, sujeito à castração, ao mesmo tempo em que se coloca na posição de mestre.

Por sua vez, também para continuar existindo, a teoria psicanalítica deve ser transmitida e estabelecer contribuições com outros campos do conhecimento, porém, uma condição deve ser preservada: a psicanálise não pode ser apresentada como um dogma ou confundida com uma ciência positiva.

A contribuição da psicanálise não será a de alimentar a ilusão de que o saber se constitua, mesmo num futuro distante, numa totalidade fechada. Por outro lado, como desde seus primórdios, o ensino da psicanálise retoma a posição dos sujeitos em relação com o conhecimento e com a noção de verdade. Por isso, permite um questionamento no interior da educação.

A presente tese tenciona demonstrar que a psicanálise oferece 
condições de sustentar uma interrogação sobre uma pretensa "Pedagogia Científica", que engendra um ideal de prática educativa e, conseqüentemente, imprime traços ideais de um suposto educador, arbitrando sobre o que lhe supõe útil na formação. 


\title{
CAPÍTULO III
}

\section{SOBRE O ESTILO: A TRANSMISSÃO DA PSICANÁLISE DESDE FREUD}

\author{
“A psicanálise não só estimulou e \\ enriqueceu a ciência médica, mas também \\ o mundo mental do artista e do pastor, do \\ historiador e do pedagogo" (Trecho da \\ menção, escrita pelo prefeito de \\ Frankfurt, ao conceder o Prêmio Goethe \\ a Freud, em 1930).
}

Quando se pretende apresentar um estudo sobre a formação de um conceito, de uma teoria ou de um estilo, o pesquisador se vê diante da necessidade de estabelecer um limite no retrocesso, além de se contentar com a abordagem de uma parte das possíveis influências, ao invés de ter a pretensão de contemplar todas as suas ramificações e enraizamentos.

Para conhecer o estilo de Freud ao ensinar a psicanálise, tanto na exposição oral quanto na escrita, faz-se necessário descobrir seus modelos. Essa investigação pode ser feita a partir de comentadores que se ocuparam especificamente dessa pesquisa, ou das indicações oferecidas pela própria pessoa em questão. Optou-se, aqui, em iniciar pelo segundo caminho, mas o auxílio de outros autores será imprescindível ao longo do texto.

Em 1925, no texto Um Estudo Autobiográfico, Freud escreve: “... no laboratório de Ernst Brücke, encontrei tranqüilidade e satisfação - e também homens que pude respeitar e tomar como meus modelos: o próprio grande Brücke e seus assistentes, Sigmund Exner e Ernst Fleischl von Marxow" (1988, p. 17). Deixando o laboratório de fisiologia por sugestão do próprio Brücke, que sabia da sua precária situação financeira, Freud ingressa no Hospital Geral: “... e trabalhei em vários departamentos do hospital, entre outros por mais de seis meses sob a orientação de Meynert, cujo trabalho e 
personalidade muito me haviam impressionado quando eu ainda era estudante" (idem, p. 18). Meynert propõe-lhe dedicação à anatomia do cérebro, mas um interesse maior o conduziu para o estudo das doenças nervosas. A escassez, em Viena, de trabalhos e especialistas no assunto contribuiu para o encontro com um novo mestre: "A distância brilhava 0 grande nome de Charcot,..." (ibid., p. 19). No retorno, mesmo encontrando má recepção da sociedade médica sobre o que aprendera com Charcot, manteve-se interessado pelo uso da hipnose e os efeitos da sugestão, métodos de tratamento que o Dr. Josef Breuer já vinha empregando no caso Anna O.. Da aproximação com esse "homem de notável inteligência" (ibid., p. 26), Freud conclui: "Nessa relação só eu naturalmente tive a ganhar" (ibid., p. 26). Apesar do nome de Willelm Fliess não figurar nesse trabalho autobiográfico, deduz-se sua importância do grande volume de cartas que Ihe foi dedicado e por nele encontrar depositada a esperança de Freud por explicações fisiológicas que o resgatassem do campo da psicologia na descrição dos fenômenos psíquicos.

Theodor Meynert é citado no texto de 1900, A Interpretação de Sonhos, tendo sido representado em sonho pela figura do pai de Freud:

Aqui, a figura que ele representava era nada mais, nada menos que o grande Meynert, cujas pegadas eu seguira com profunda veneração $e$ cujo comportamento para comigo, após um breve período de predileção, transformara-se em hostilidade indisfarçada (1987, p. 470).

Ernest Jones (1979) conta que as preleções de Meynert haviam sido as únicas lições médicas que provocaram interesse de Freud como estudante e que sempre era lembrado como o gênio mais brilhante que jamais encontrara. No entanto, além do reconhecimento como o maior anatomista, parece não existir referências sobre o estilo de Meynert como modelo de mestria.

A admiração por Breuer, "um homem de fecundos e universais talentos, cujos interesses se ampliavam para além de sua atividade profissional" (Jones, 1979, p. 235), correspondia com o prestígio que o mesmo recebia em Viena, com o mérito dos trabalhos científicos que havia produzido e, de certa maneira, pela função que desempenhou durante certo 
período na vida pessoal de Freud: uma espécie de tutor. Sua dedicação aos pacientes e a grande experiência no trabalho clínico contribuiu para a investida inicial de Freud nessa atividade. Exceto no que se refere ao emprego do método hipno-catártico, Breuer figura muito mais como um excelente provedor e incentivador do que propriamente um mestre. Aliás, retirou-se do cargo de Privatdocent e recusou o título de professor para dedicar-se às tarefas da clínica privada.

A confiança e a admiração de Freud por Fliess é, até certo ponto, algo que pode parecer estranho. Apesar do fato "admirável" de ser um homem mais novo e de maior prestígio profissional que Freud na época das correspondências, Fliess, efetivamente, pouco contribuiu com as pesquisas de Freud. Se, por um lado, contribuiu com a tese da bissexualidade, por outro, vê-se certo esforço e certa dificuldade de Freud em encontrar simetria entre as produções, o que, muitas vezes, o levou a atribuir a Fliess uma capacidade e conhecimento maiores do que o que ele próprio possuía, não se vendo capaz de colaborar com as pesquisas do colega e, apenas limitava-se a confiar na possibilidade deste vir a dissolver suas dificuldades ${ }^{35}$ com a teoria do aparelho psíquico. Portanto, é possível concluir que o que realmente caracterizou o relacionamento entre ambos não diz respeito à mestria de Fliess, mas ao lugar que Freud o coloca em seu campo transferencial (como Sujeito Suposto Saber), num momento em que produzia duas importantes obras (Projeto para uma Psicologia Científica e $A$ Interpretação de Sonhos) e necessitava de um interlocutor, já que não havia mais ninguém com quem pudesse discutir os impasses que se the apresentavam. Sobretudo, permanecia a busca por um suposto novo mestre sob o qual pudesse se colocar em posição de dependência, desde que rompeu sua amizade com Breuer.

Meynert, Breuer e Fliess permaneceram como modelos de mestria, de profissionalismo ou competência durante períodos que iniciavam com uma grande admiração e terminavam com profundo ressentimento. Meynert não admitia a existência da histeria masculina, apesar de ter confessado pouco antes de sua morte: "Você sabe, sempre fui um dos casos mais claros

\footnotetext{
${ }^{35}$ Ausência de fundamentos fisiológicos.
} 
de histeria masculina" (Freud, [1900] 1987, p. 471). Breuer não reconhecia a etiologia sexual das neuroses e deixou de oferecer seu prestígio a favor de Freud, a fim de preservar o respeito que tinha diante da sociedade médica. A Fliess, Freud atribui a causa de seu ataque de completa inibição para 0 ato de escrever, quando da iminência da exploração do seu inconsciente e a notável dependência em relação ao amigo. A hostilidade entre eles começa a surgir numa disputa científica e culmina na publicação feita por Fliess de um panfleto acusando Freud de ter contribuído com um caso de plágio, em que dois outros nomes são envolvidos. Freud responde imediatamente numa publicação: "O que nos diz respeito é uma defesa contra a autoritária presunção de uma personalidade grosseira e a expulsão do templo da ciência de uma ambição pessoal mesquinha" (Jones, 1979, p. 319).

Em novembro de 1899, Freud é solicitado a enviar seu perfil profissional para o Léxico Biográfico dos Médicos Eminentes do Século XIX, organizado por Julius Pagel. Em sua descrição autobiográfica, Freud precisou dizer quem tinham sido os seus mentores. Nenhum dos três nomes citados a pouco apareceu, mas o de outros dois: Ernst Brücke e Jean-Martin Charcot.

"...sob a influência de Brücke, que teve mais influência sobre mim do que qualquer outra pessoa em toda minha vida, ..." (1988, p. 243), surpreendente declaração contida no Pós-Escrito de A Questão da Análise Leiga, de 1927, que sucede três outras raras e rápidas referências ao nome de Brücke: em A Interpretação de Sonhos (1900), nas Conferências Introdutórias (1915-17) e no Ensaio Autobiográfico (1925). Tal inigualável influência contrasta com a escassez de referências de Freud ao nome de Brücke. $\mathrm{E}$, tendo em vista que se manteve como discípulo deste durante oito anos, de 1874 a 1882, no início como estudante de medicina, depois trabalhando no laboratório que Brücke dirigia, é curioso perceber que Freud não faz nenhuma exposição sobre o uso da linguagem por esse mestre, ou mesmo sobre suas atitudes frente ao discurso. Patrick J. Mahony, psicanalista e docente em literatura inglesa em Montreal, apresenta duas causas prováveis dessa falta: a primeira, pelo fato de que as conferências de Brücke tendiam a ser difíceis e complicadas para seus alunos (segundo autobiografia de Moritz Benedikt, de 1906); e, segundo, na revelação feita 
pelo neto de Brücke em sua biografia de 1928, de que "o discreto Brücke abstinha-se de falar, mesmo com amigos da mesma especialidade, sobre qualquer trabalho em andamento; somente quando a idéia estava plenamente amadurecida é que ele se dispunha a discuti-la" (1990, p. 19).

Pode-se deduzir tratar-se de um mestre pouco sedutor, com um discurso incapaz de envolver o público. Também parece pouco provável que se encontre alguma identidade entre o estilo de Brücke e o de Freud, já que esse último, aparentemente, tendia a privilegiar o que chamava de método genético, em detrimento do método dogmático que (como indica a segunda causa apontada por Mahony) caracterizava o discurso de Brücke. Mais adiante, a discussão feita por Freud sobre o método dogmático e genético para a exposição escrita e oral será retomada neste texto.

Apesar do curto período em que Freud se manteve como aluno de Charcot (dezessete semanas, de onde foram extraídos nove dias de visita à sua noiva), foi justamente esse encontro que conduziu sua mudança da orientação neurológica para a orientação psicopatológica. Os efeitos da experiência em Paris tiveram um caráter excepcionalmente duradouro.

Freud traduziu as conferências de Charcot para o alemão, que formaram dois volumes: um contendo as conferências públicas que foram minuciosamente preparadas antes da apresentação e outro contendo as famosas Leçons du Mardi, as conferências feitas de improviso. Se Freud considerava as primeiras como pequenas obras de arte em termos de construção e composição, que conseguiam fascinar a audiência, as outras, que demonstravam a técnica instrutiva de Charcot na clínica de atendimento da Salpêtrière, Ihe renderam um fascínio maior. Isto porque:

não escapou à observação de Freud o fato de as Leçons du Mardi serem muito mais populares do que as conferências formais, apesar da mestria artística que estas demonstravam. (...) Elas incluíam a franqueza e a coragem de pensar em voz alta; o modo democrático de atrair a audiência para um empreendimento científico comum; a revelação das dúvidas, das hesitações e dos obstáculos que surgiam repentinamente; uma preocupação de investigar as origens; e o exame das implicações mais amplas do assunto em questão. (Idem, p. 20-22)

Dotado de sensibilidade e uma capacidade de observação perspicaz, pode-se acreditar que Freud não deixou de examinar com minúcia os 
aspectos comunicacionais de Charcot, servindo-Ihe de um eficiente modelo de exposição para a difusão da psicanálise. Em suma, supõe-se que Charcot tenha sido uma importante influência no estilo de transmissão oral e escrita que Freud apresenta, principalmente seu estilo nas Leçons du Mardi.

\section{O método dogmático e o método genético na transmissão da psicanálise por Freud}

Diferente das classificações mais comuns de seus escritos, que consideram o tema (antropologia, mitologia, história da religião, arte, literatura, etc) e o gênero (ensaio teórico, história, diálogos, autobiografias, cartas, etc), Freud sugere inicialmente uma divisão de sua obra em função do estilo: dogmático e genético (Mahony, 1990).

Apesar de algumas vezes mencionar os dois métodos em textos anteriores (como nas Novas Conferências Introdutórias Sobre Psicanálise, de 1933), Freud se dedica um pouco mais na exposição dos mesmos em Algumas Lições Elementares de Psicanálise, texto escrito em 1938 e publicado em 1940: "Um autor que se dispõe a introduzir algum ramo do conhecimento - ou, para falar de modo mais modesto, algum ramo da pesquisa - para um público não instruído tem claramente de fazer sua escolha entre dois métodos ou técnicas" (1988, p. 301).

Para não surpreender o público, causar resistências e para poder envolvê-lo no desenvolvimento de uma idéia, parte-se de um campo supostamente conhecido pelo público e trilha-se o caminho percorrido pelo próprio investigador, aplica-se, dessa forma, o método genético:

\footnotetext{
É possível partir daquilo que todo leitor sabe (ou pensa que sabe) $e$ encara como auto-evidente, sem, em primeira instância, contradizê-lo. Logo ocorrerá oportunidade de chamar a atenção dele para fatos do mesmo campo que, embora lhe sejam conhecidos, até então negligenciou ou apreciou de modo insuficiente. Partindo destes, podem-se-lhe apresentar novos fatos dos quais não tem conhecimento e assim preparálo para a necessidade de ultrapassar seus juízos anteriores, de procurar novos pontos de vista e de levar em consideração novas hipóteses. Dessa maneira, pode-se conseguir que ele tome parte na construção de uma teoria sobre o assunto, e lidar com suas objeções para com ela durante o
} 
decurso concreto do trabalho conjunto. Um método desse tipo bem poderia ser chamado de genético. (Idem, p. 301)

O investigador ou preletor pode, também, optar por "experimentar" a receptividade do ouvinte/leitor:

O outro método, o dogmático, começa diretamente pelo enunciado de suas conclusões. Suas premissas fazem exigências à atenção e à crença da assistência, e muito pouco lhes é aduzido em apoio. E há ainda a perigo de que um ouvinte crítico balance a cabeça e diga: 'tudo isso soa muito peculiar; de onde foi que esse sujeito o tirou? (Ibid., p. 301)

O método dogmático é formal em sua expressão, seu procedimento é dedutivo, exige atenção do público, pode ser apresentado de forma mais sintética, mais acabada, causando a impressão de uma estrutura teórica completa.

Há uma tendência de alguns autores em considerar uma alternância e combinação entre o método dogmático e genético na transmissão da Psicanálise por Freud. Assim também Freud sugere em Algumas Lições Elementares de Psicanálise. No entanto, é possível observar certa predileção pelo método genético (tal como Mahony sugere em Sobre a definição do discurso de Freud), visto que, com freqüência, Freud introduz um interlocutor imaginário em seus textos, sob a forma de objeções imaginárias.

No prefácio das Novas Conferências Introdutórias sobre Psicanálise, de 1933, (que na verdade não se tratavam de conferências, mas um artifício de imaginação para dialogar com o leitor) Freud nos indica uma característica de seu estilo:

Também desta vez, meu objetivo principal foi o de não fazer concessões que visassem a dar uma aparência de que as coisas sejam simples, completas, acabadas, procurei não camuflar problemas e não negar a existência de lacunas e incertezas. (1988, p. 16)

Quando se percebe na impossibilidade de seguir o método genético, Freud apresenta uma justificativa ao leitor para fazer uso do outro método. No mesmo texto, pode-se ler: 
paciente assumiram uma forma que é ininteligível tanto para ele como para nós? Como vêem senhoras e senhores, desta vez estou tomando o caminho não de uma exposição genética, mas de uma exposição dogmática. Nosso primeiro passo consiste em estabelecer nossa nova atitude para com o problema dos sonhos, introduzindo dois novos conceitos e nomes [sonho manifesto e pensamentos oníricos latentes] (idem, p.19).

Pode-se questionar se a preferência por um ou por outro método de transmissão se relaciona com o estilo próprio do investigador ou com uma especificidade da construção teórica a ser transmitida. Em outras palavras, imagina-se que o método supostamente preferido por Freud, o genético, não atenda apenas a seu estilo, mas a uma possível especificidade do ensino da psicanálise, provavelmente, a uma exigência do objeto sobre o qual ela se debruça.

Em Freud e o Ato de Ensino, Tânia Ferreira afirma: "Mas se intitulo assim meu trabalho, é porque considero o ensino de Freud um ato, no sentido psicanalítico do termo" (1998, p. 109). É porque Freud apresenta um estilo exploratório na transmissão da psicanálise que ela é identificada como uma experiência psicanalítica. $E$, se essa última possui um caráter interminável, também a escrita freudiana conserva infinitos pontos a serem explorados em leituras sucessivas. Explorar, inclusive, a própria transferência estabelecida com Freud. Uma exploração interminável, como a própria análise.

Mais adiante, neste trabalho, a questão do objeto em psicanálise e da identificação com Freud em suas relações com a transmissão será um pouco mais explorada, a partir do debate sobre ensino e transmissão nas instituições psicanalíticas e no ensino aberto (aos não analistas).

Mahony indica duas modalidades do procedimento genético de Freud: a pública e a privada.

Esplêndido pedagogo, em sua escrita pública genética Freud esforçou-se por se avizinhar do progresso do tratamento analítico; visava, assim, não somente a estimular a audiência a pensar e sentir, mas também a lidar com suas resistências e facilitar seus processos associativos (1990, p. 27).

Frente a uma platéia, Freud se mantinha atento à irracionalidade e objeções à elaboração de sua comunicação. Assim sendo, tal procedimento 
não consistia somente numa reconstituição, junto ao público, de toda via de investigação percorrida, mas também num apelo para que o julgamento se mantivesse suspenso e, assim, "deixar que o assunto agisse sobre eles" (1976, p. 289), expressão que Freud utiliza nas Conferências Introdutórias sobre Psicanálise (de 1915 a 1917). Portanto, o método genético público teria a função de despotencializar as resistências do público leitor e do público ouvinte, estimulando-lhes as associações.

Segundo Mahony, no procedimento genético privado, o discurso é utilizado para estimular as associações do autor e se apresenta sob a forma de uma escrita exploratória: "...efetivamente explora processos em andamento; em vez de dizer algo previamente planejado, lembra a livre associação autêntica, na qual o paciente fala buscando descobrir o que pensa" (1990, pp. 28-29). Em algumas cartas, Freud comenta a espontaneidade de seu trabalho, como se observa na carta a Fliess de 7 de julho de 1898:

Ele segue completamente os ditames do inconsciente, segundo o célebre princípio de Itzig, o viajante dominical: “- Itzig, para onde você vai? -E eu sei? Pergunte ao cavalo.” Não iniciei um só parágrafo sabendo onde ele iria terminar. (Masson, 1986, p. 320) ${ }^{36}$

Seguindo ainda as orientações propostas por Mahony, a partir de dois textos cronologicamente distantes no conjunto da obra freudiana $O$ Caso Clínico de Katharina (1893) e Análise Terminável e Interminável (1937), o autor nos mostra uma relação entre o que talvez se possa chamar de discurso interior e discurso público de Freud. Além de expor alguns elementos do cenário que Freud vivenciou no momento da produção de cada um dos textos, Mahony destaca uma capacidade de reagir aos próprios processos associativos e à sua afetividade: "Sua imaginação é aguçada por sua disposição de escrever sob a influência de intensa emoção" (1990, p. 67). O autor designa por uma terceira mão e um terceiro ouvido a capacidade de Freud em participar e, ao mesmo tempo, observar o processo analítico (idem, p. 104). A partir do discurso genético, Freud encena, domina

\footnotetext{
${ }^{36}$ Mahony sugere que a maioria dos psicanalistas inicia suas escritas conforme o estilo de Freud, porém, logo o abandonam. Mais adiante, apresentar-se-á uma discussão acerca da transmissão da psicanálise hoje.
} 
e descreve os processos inconscientes.

Apontando intermináveis limitações na tradução de Strachey (algumas delas provenientes de peculiaridades da língua alemã, especialmente no que concerne aos tempos verbais; dentre outros motivos), Mahony pretende mostrar que as características do discurso oral e escrito de Freud (definições flexíveis, termos vigorosos, termos do cotidiano, tempo verbal subjuntivo...) não se devem exclusivamente a um atributo pessoal, mas que a definição desse discurso se impôs como condição necessária ou, até mesmo, via de transmissão legítima da psicanálise por, no mínimo, três razões: primeira, por tratar-se de uma ciência em desenvolvimento, procurando atender ao ideal científico de elaborar generalizações fundamentadas em observações particulares; segundo, por fazer justiça à especificidade do material psíquico, fundamentalmente o incognoscível inconsciente; terceiro, pelas limitações intrínsecas à linguagem verbal, que apenas margeia a complexidade da vida inconsciente.

Para finalizar, uma breve observação sobre o estilo do ensino de Freud, frente à criação de uma suposta nova ciência: "Uma característica fundamental do discurso genético de Freud é a utilização de uma linguagem ressonante com objetivos científicos" (idem, p. 103).

A empreitada de Freud em apresentar uma nova ciência não poderia ser simples. Sua linguagem deveria, até certo ponto, ultrapassar a realidade da existência de um número finito de palavras para comunicar a infinita multiplicidade da experiência humana, um limite, como é sabido, enfrentado no âmbito individual. Além da evidência de que, devido às histórias pessoais únicas, os sentidos que se atribui às palavras são característicos, e tanto mais o são quanto mais comum é a palavra (Mahony, 1987).

Vivendo uma época em que a linguagem interior parecia entrar em declínio para dar lugar a uma linguagem científica supostamente universal, havia o desafio não somente de comunicar, mas de traduzir o funcionamento psíquico. Nesse contexto, Freud nomeia a repressão como o próprio fracasso de tradução e a transferência como uma tradução metafórica 
possível. Os significados fixos e unívocos que atenderiam à demanda da comunidade científica não são apropriados para a descrição dos processos psíquicos.

... o desafio global que se coloca diante de Freud, o analista-escritor, é o buscar o ideal científico de elaborar generalizações fundamentadas em observações particulares e ao mesmo tempo fazer justiça à especificidade do material psíquico. (...) Para ser mais preciso, o desafio descritivo com que Freud se deparou era duplo, pois os fenômenos que abordava inclinavam-se a mudar gradualmente, e jamais por completo (Idem., p. 99).

Ao lado da exigência por uma linguagem universal, que Mahony enfatiza, deve-se recuperar a característica do pensamento romântico observada por Lo Bianco:

O que se pode depreender do incansável gesto freudiano de interlocução com o pensamento romântico e, mais do que isso, sua cuidadosa $e$ criteriosa adoção da perspectiva romântica; assim como o que se pode reter de seus laboriosos desenvolvimentos na área da medicina neurológica, conduzem-nos a reafirmar que só ao se deixar atravessar pelos significantes que o circundavam (...) foi-lhe possivel fundar o caminho de radical originalidade que foi o seu (2002, p. 158).

\section{Da transmissão à formação: as instituições psicanalíticas}

Tendo rompido a relação de quinze anos com Fliess, cuja correspondência e encontros (viagens de férias que nomeavam "congressos") renderam, além de uma auto-análise, a produção dos importantes textos já mencionados, Freud compõe, em 1902 a Sociedade Psicológica das Quartas-Feiras. Concomitante à produção de trabalhos psicanalíticos, a transmissão da teoria teve sua formalização oficial na composição desse grupo que, além do líder fundador, contava com: Wilhelm Stekel, Max Kahane, Rudolf Reitler e Alfred Adler.

Apresentação de textos e de casos clínicos, psicanálises de obras literárias e de personalidades públicas, resenhas de novos lançamentos psiquiátricos e apresentações prévias de futuras publicações dos membros, somados a auto-exibições científicas (confissões acerca da própria 
intimidade sexual), conversas sociais, café preto, bolos, charutos e cigarros, caracterizavam o ritual dessas reuniões. Ritual muitas vezes comparado ao de uma religião.

Em 1906, a Sociedade Psicológica das Quartas-Feiras passava a contar com dezessete membros. Apesar das adesões crescentes, Jones e Abraham, dentre outros, observaram um distanciamento entre a produção do grupo vienense e a genialidade de Freud. Nessa altura, as reuniões já apresentavam muitas manifestações de irritação, disputa por posições, expressões brutais de antipatia entre os colegas e, até mesmo, insultos. Freud propõe, em 1908, a dissolução do grupo informal para reconstituí-lo como a Sociedade Psicanalítica de Viena, dando oportunidade a renúncias discretas e contando com a adesão de estrangeiros: Eitigon, Jung, Binswanger, Abraham, Brill, Jones e Weiss, que se destacavam em relação aos vienenses.

Alcançando seguidores de vários pontos do continente europeu até a América, o desenvolvimento, a preservação e a transmissão da teoria psicanalítica passou a representar grande preocupação de Freud e, até hoje, se constitui um tema bastante polêmico, que acompanha freqüentes formações e rompimentos de grupos psicanalíticos em diversos países.

Com a visita de Freud aos Estados Unidos, em 1909, e com a realização do primeiro Congresso Psicanalítico em Salzburg (por iniciativa de Jung), começa a ser gestada a idéia de fundar uma associação oficial que fosse capaz de evitar as ameaças de distorções e abusos que a popularidade da psicanálise oferecia à teoria. Em 1910, no Congresso de Nuremberg, a Associação Internacional de Psicanálise foi oficialmente criada.

Desde o início, alguns entraves ameaçam a idéia da formação de um grupo coeso e suficientemente forte para desenvolver, preservar, transmitir e representar a teoria. Oposições internas foram manifestas já em sua fundação, dentre elas, as de psicanalistas vienenses, em vista da mudança do centro do movimento psicanalítico para Zurich. Em 1913, no Congresso de Munique, alguns sérios desentendimentos haviam ocorrido entre Freud e Jung, que acabara de ser reeleito à presidência.

Resistindo às "pesquisas independentes" de Jung e Adler, em 1914, 
Freud declara publicamente que a psicanálise não havia mudado e, portanto, não reconhecia as inovações teóricas empreendidas por cada um.

Somavam-se a esses desentendimentos as disputas por prioridade nos trabalhos realizados em comum e a incapacidade dos membros do grupo em estabelecer relações de amizade e solidariedade. Diante disso, Freud cria, em 1913, um comitê secreto, cujo objetivo era de controlar a ortodoxia das pesquisas psicanalíticas. Funcionou bem durante cerca de dez anos, segundo Jones (1979), após o que surgiram intrigas, suspeitas e denúncias mútuas junto a Freud.

Com intuito de preparar o atendimento psicanalítico das massas, realizar pesquisas e promover o progresso da formação, no Congresso de Budapeste, em 1918, foram propostos critérios em torno da transmissão e formação psicanalíticas. Dois anos após, Eitingon, Abraham e Simmel fundaram o Instituto de Psicanálise de Berlin, cujas atividades estavam sistematizadas da seguinte maneira:

\footnotetext{
haveria uma pré-seleção dos candidatos, cujo exame e eventual promoção deveria ser feita irrevogavelmente a partir de três entrevistas; em seguida, o candidato deveria passar por uma análise pessoal de no mínimo seis meses, com um analista designado pelo Comitê de Formação, cabendo ao mesmo decidir quando a análise estaria "suficientemente adiantada" para que o estudante passasse para as etapas de formação e, finalmente, quando essa deveria ser encerrada. Finalmente, a partir de 1932, o candidato deveria assinar um termo de compromisso de que só se autodenominaria psicanalista após sua admissão formal pela Sociedade de Psicanálise (Vale, 1986, p. 49).
}

Desde aí, a formação psicanalítica conta, principalmente, com um modelo triádico: análise pessoal, supervisão e formação teórica, porém, tende a guardar as especificidades da história de cada Sociedade local. Dentre tais especificidades históricas destaca-se, por exemplo, a particularidade da recepção e desenvolvimento mais tardios (após o final da Segunda Guerra Mundial) da teoria psicanalítica na França.

Diferente do predomínio médico no diálogo com os Estados Unidos e Alemanha, na França, o interesse pela psicanálise surge inicialmente entre os filósofos, alcançando a lingüística e a literatura. Fato que promove uma aceitação, até certo ponto, incomum das instituições universitárias.

A experiência francesa da psicanálise no contexto universitário 
compreende uma história descrita com muitos detalhes por Elisabeth Roudinesco (1988). Os personagens dessa história protagonizam sucessivos conflitos, desde o âmbito político (oposição de grupos de direita e de esquerda na formação dos câmpi universitários) até mesmo envolvendo contestações provenientes das sociedades psicanalíticas, especialmente da corrente médica e conservadora da Sociedade Psicanalítica de Paris.

Em 1953, sob a presidência de Lacan, a Sociedade Psicanalítica de Paris cria um Instituto de Formação, conforme pedido da IPA. Dessa primeira Sociedade, surge um grupo dissidente liderado por Lacan: a Sociedade Francesa de Psicanálise. Em seguida, a Escola Freudiana de Paris, que já não estava associada à Internacional (IPA). Tais mudanças refletem o incômodo causado pelas inovações teóricas e práticas de Lacan, que culminam na cassação da sua licença de analista didata, bem como na sua expulsão e na de seus analisandos como membros da IPA.

A Escola Freudiana de Paris (EFP) traz mudanças significativas na concepção de formação, dentre as principais: a supressão hierárquica e a formação de pequenos grupos (cartéis); o redimensionamento da autorização ao exercício e a instituição do passe. Dessa forma, Lacan pretendeu desvincular a formação de um processo onipresente, apoiado na figura de autoridade, tal como foi sendo caracterizada desde o Instituto de Berlim.

Em 1980, a EFP é dissolvida por Lacan. Disputas e oposições fragmentam o grupo lacaniano em várias organizações pela França, refletindo também nos grupos brasileiros.

Atualmente, o movimento iniciado por Lacan continua através das novas gerações de psicanalistas, dentro e fora da França, que se declaram empenhados em recuperar o eixo da análise freudiana, em oposição à transmissão que vinha se delineando num período de quarenta anos, considerada desviante do ideal do fundador ${ }^{37}$.

\footnotetext{
${ }^{37}$ Tema que sera apresentado em mais detalhes na página 113.
} 
As teses freudianas começaram a circular no Brasil a partir de 1914, com a apresentação de um trabalho do, então, jovem médico baiano Juliano Moreira, na Sociedade Brasileira de Psiquiatria, Neurologia e Medicina Legal. Ainda em 1899, segundo informações pouco precisas, Moreira teria comentado as teses de Freud na Faculdade de Medicina da Bahia, após ter concluído sua formação na Alemanha, com Kraepelin ${ }^{38}$. Da influência exercida sobre os colegas nasceram as primeiras pesquisas brasileiras orientadas pela psicanálise, dentre elas, "Da Psychanalyse: a Sexualidade das Neuroses" (1915), de Genserico Aragão de Souza Pinto.

No Rio de Janeiro, a partir de 1919, Júlio Pires Porto-Carrero se propõe a ler os textos originais de Freud e, para tanto, estuda o idioma alemão. Inicia sua clínica no ano de 1923, na Liga Brasileira de Higiene Mental.

Em São Paulo, o debate em torno da psicanálise começa com a publicação do livro O Pansexualismo na Doutrina de Freud, de Franco da Rocha. Apesar de ter possuído um precursor psiquiatra, segundo Oliveira (2002), a psicanálise encontrou, inicialmente, maior interesse nos intelectuais dessa cidade, especialmente na literatura modernista, que refletia sobre a questão da identidade nacional.

Diversos nomes são citados no período inicial da introdução da Psicanálise no Brasil: Henrique Belford Roxo a introduz no seu curso de psiquiatria e dedica-lhe grande destaque em seu Manual de Psychiatria (1921); Antonio Austregésilo, médico, reconhece o papel da sexualidade na constituição das neuroses; Afrânio Peixoto a introduz em seu curso de psiquiatria médico-legal na Faculdade de Medicina do Rio de Janeiro, em 1918.

Empenhados num "projeto de construção da nação brasileira":

Essa geração de médicos tem como missão o estabelecimento de medidas profiláticas com vistas a corrigir os 'defeitos', garantir uma 'procriação sadia' e formar uma 'boa geração' de brasileiros, capaz de 'enobrecer' o

\footnotetext{
${ }^{38}$ Emil Kraepelin (1856-1926) “(...), se Sigmund Freud adotou parte dos conceitos do mestre de Munique, inscreveu sua clínica em uma trajetória radicalmente inversa à sua. Fundando sua prática na escuta do sujeito, situava-se na posição oposta a Kraepelin, que era herdeiro de uma clínica do olhar fundada na prevalência do corpo, na ausência do doente. Kraepelin pensava, efetivamente, que a ignorância da fala do paciente garantia, na medicina mental, a melhor observação" (Roudinesco; Plon, 1998, p.441).
} 
Dessa maneira, a psicanálise termina por representar uma contribuição de valor científico a um programa preventivo de educação sexual que alcançaria a família e a escola.

Em termos de um grande empenho, difusão e introdução de uma prática psicanalítica propriamente dita, Durval Marcondes ${ }^{39}$ é considerado 0 fundador do movimento psicanalítico brasileiro. Discípulo de Franco da Rocha, desde sua formação no curso de medicina, em 1927, dedicou-se à difusão e desenvolvimento da teoria psicanalítica no Brasil. Organizou a Sociedade Brasileira de Psicanálise do Rio de Janeiro em 1928; ministrou cursos sobre psicanálise para grupos de médicos da Santa Casa de Misericórdia de São Paulo e para educadores sanitários do Instituto de Higiene da Universidade de São Paulo; sonhou com uma formação profissional de analistas numa instituição universitária; fundou em seu consultório a primeira Sociedade Psicanalítica de São Paulo; iniciou a publicação da Revista Brasileira de Psicanálise; empenhou-se em trazer analistas didatas do exterior, mesmo enfrentando pressões da comunidade médica da época e um cenário político desencorajador. A Sociedade Brasileira de Psicanálise de São Paulo foi reconhecida pela IPA em 1951 (Vale, 1986).

A psicanálise é introduzida na universidade brasileira, por Marcondes, desde a década de 40. Em 1954, organizou o curso de Psicologia Clínica e a Clínica Psicológica da Universidade de São Paulo. Em 1977, leciona Psicoterapia Psicanalítica num curso de especialização da Pontifícia Universidade Católica de São Paulo. Desde 1971, Magno Machado Dias começa a difundir as leituras lacanianas em universidades do Rio de Janeiro $^{40}$. Já na década de 60 , a psicanálise é introduzida nos cursos de psicologia, a partir de supervisões e disciplinas como Psicologia do Desenvolvimento.

Marcondes também expressou sua intenção de lecionar os

\footnotetext{
${ }^{39}$ Segundo Oliveira, no início do movimento, Marcondes não dispunha de boas entradas no universo psiquiátrico paulista e menos ainda no meio universitário.
} 
rudimentos de psicanálise aos alunos de graduação em psicologia,

Os cursos de psicologia funcionaram como canal de divulgação da maneira de pensar psicanalítica. Ainda hoje, e mesmo com a predominância de outras correntes no currículo, alguns cursos - como o da Universidade de São Paulo, onde trabalham vários analistas experientes - proporcionam aos estudantes um primeiro contato com a psicanálise, o que freqüentemente os estimula a buscar uma formação nas instituições propriamente psicanalíticas (Mezan, 2002, p. 239).

A partir dos anos 80 , a teoria psicanalítica se expandiu para a pósgraduação. Nesse contexto, a psicanálise tem composto subáreas nos programas de mestrado e doutorado em Institutos como o de Psicologia, de Educação, de Lingüística e de Filosofia. Mais recentemente, em 1998, os docentes do curso de Especialização do Departamento de Psicologia Clínica do Instituto de Psicologia da Universidade do Estado do Rio de Janeiro criaram a primeira turma, com doze vagas, do Mestrado em Pesquisa e Clínica em Psicanálise. Até o momento, é um dos raros cursos com um programa de ensino com a finalidade de um diploma específico em psicanálise (Alberti, 2000). Hoje, segundo Alberti, o Brasil é um dos países em que mais psicanálise há nas universidades.

Fugindo ao objetivo deste trabalho uma descrição mais detalhada da história das instituições psicanalíticas no Brasil e no mundo, no breve panorama descrito acima, já é possível perceber uma permanente tensão no propósito manifesto desde a Sociedade Psicológica das Quartas-Feiras, no sentido da preservação, difusão e, no cerne da polêmica, a transmissão da teoria.

As Sociedades de Psicanálise e Institutos de Formação que desde o princípio buscavam um modelo diferente da instituição universitária, essencialmente compreendida como impositiva e rejeitadora, vêem-se repetindo, nas inúmeras experiências de constituição e dissolução, situações

\footnotetext{
${ }^{40}$ Onde foi criado, em 1983, o Instituto Jacques Lacan, como decisão do Colégio Freudiano do Rio de Janeiro. No Instituto, a formação foi reorganizada hierarquicamente, a saber: curso básico, suplementar, mestrado e doutorado.
} 
marcadas pelo desejo de poder. Suas estruturas hierarquizadas, evidente na relação com a IPA como instância de reconhecimento, delegam a autoridade do saber sobre psicanálise ao topo dessa hierarquia, que decide desde a duração das análises, o tempo e o conteúdo dos cursos, a seqüência em que os candidatos devem cumprir as três partes da formação, até, sobre a qualificação ou não dos analistas. "Terreno fértil ao desenvolvimento de relações baseadas na sedução, na sugestão, em lutas, brigas, comparações, etc" (Vale, 1986, p. 92).

Ao se apresentarem como instituições delimitadas por modelos e pelo tempo cronológico, as sociedades e institutos psicanalíticos reproduzem aquilo mesmo que Freud anunciou como a "contramão" da transmissão do saber psicanalítico: o dogmatismo. Privam os candidatos da possibilidade de conviver com o imprevisto que caracteriza o material inconsciente.

Atualmente, são articulados muitos debates em torno da questão das instituições psicanalíticas. Um dos mais expressivos resulta das reflexões conduzidas pelos Estados Gerais da Psicanálise. Cavalcanti, Cardoso e Rocha, membros do Círculo Psicanalítico de Pernambuco, recuperam o questionamento de Roudinesco, em Dix Propositions de Réflexions pour les États Généraux de la Psychanalyse, sobre as formas possíveis de uma instituição psicanalítica ser capaz de resistir à burocratização das grandes instituições e à divisão dos infinitos grupos que reivindicam legitimidade ${ }^{41}$.

As autoras pernambucanas pensam a possibilidade de instituições psicanalíticas mais fraternas e democráticas e, simultaneamente, mais produtivas e criativas. Inicialmente, circunscrevem os conceitos instituição e organização, considerando uma freqüente confusão no emprego do primeiro conceito. A instituição "funda e estabelece uma certa modalidade de relações sociais (...) dando sustentação à identidade de um grupo e afetando os valores..."; a organização é a "forma e o modo de operação de determinados dispositivos que dão concretude ao que é institucionalmente estabelecido" (2000, p. 112). Em seguida, afirmam que "a própria psicanálise já tem uma dimensão institucional, enquanto saber constituído no campo dos saberes sobre a condição humana" (idem, p. 113) e que, em nível de

\footnotetext{
${ }^{41}$ Em trabalho apresentado no Encontro Sul-Americano dos Estados Gerais da Psicanálise, realizado em São Paulo, em novembro de 1999.
} 
instituições mais específicas, estão as escolas que se desenvolveram em torno da produção psicanalítica. A dimensão organizacional é representada por uma sociedade, um instituto, um programa de ensino dentro de um departamento universitário, e pelos grupos informais.

Quatro posições sustentam uma sociedade psicanalítica concebida pelas autoras: um posicionamento contínuo de interrogação e a convivência com as incertezas e impossibilidades; os acordos entre pares que sustentam uma construção coletiva e eliminam tentativas de que o poder seja atribuição de um membro apenas; gestão assentada em relações fraternas e democráticas; e, finalmente, "disposição para enfrentar o risco de uma produção plural que leva ao permanente questionamento do estabelecido" (ibid., p. 116).

Nota-se que as discussões acerca das instituições psicanalíticas buscam, em última instância, algo de elaboração que as coloque em condições de fugir do "reencontro do mesmo", daquilo que descreve o lugar de uma compulsão repetitiva, que a teoria psicanalítica conhece intimamente. Foi depois da Segunda Guerra Mundial que essa discussão atingiu todas as instituições, inclusive a da Filosofia da Ciência e da Epistemologia. Em vários artigos da década de 50, Lacan estimula a crítica da situação da psicanálise institucionalizada.

Com o propósito de operar um retorno ao descobrimento freudiano, é que se produziram as inovações de Lacan citadas anteriormente, isto é, uma proposta alternativa à formação oficial: a supressão hierárquica, os cartéis e o "passe". Foi, portanto, fundamentalmente a questão da formação do psicanalista e da transmissão da teoria que definiu a ruptura de Lacan com a IPA.

Desde a Ata de Fundação da Escola Freudiana de Paris, de 21 de junho de 1964, Lacan sugere a formalização do trabalho em cartéis. Cada cartel é formado por um pequeno grupo (entre três e cinco) que se elege entre si e que deve executar um trabalho que apresente um produto revelador da particularidade do grupo. Resumidamente, Lacan utiliza-se do termo cartel para distinguir uma prática de escola psicanalítica, marcada por dois objetivos: transmitir o que é a psicanálise, através do estudo de um tema que atenda ao interesse comum; e a função designada ao "mais um". 
O "mais um" é alguém, eleito entre os elementos do grupo, que tem a função de velar, no grupo, pelos efeitos internos e provocar sua elaboração, (como um "eco") expondo, no grupo, sua especificidade. Por conseguinte, é através dele que se dá o progresso produzido no discurso que circula no seio deste pequeno grupo. Apesar da evidente tarefa de seleção, de discussão e de revelação do resultado do trabalho de cada um, ainda não é fácil compreender a posição subjetiva de quem ocupa essa função (Safouan, apud Hoffman, 1985).

Para compreender a proposta lacaniana, é necessário recordar a noção psicanalítica de que o sujeito do inconsciente apóia-se no discurso que o estabelece. Daí a afirmação de que o sujeito é levado por um "saber não sabido". Obviamente, no cartel, os sujeitos estariam submetidos à mesma condição, tal como se encontram no seio de qualquer instituição. No entanto, compondo um cartel, o sujeito/candidato atravessa por momentos em que pode recordar seu discurso, identificar o que recebe do outro em sua própria mensagem, tendo, assim, condições de atualizá-la.

O produto que especifica o grupo é o efeito do trabalho de cada um, para além de sua contribuição formal na leitura e elaboração de um tema psicanalítico. Portanto, o produto do grupo pode ser considerado um efeito de sujeito. Nesse aspecto, o trabalho do grupo assemelha-se ao de uma análise, em que a condição de prosseguimento está apoiada no reconhecimento dos efeitos de transferência, que no caso do cartel é designado por "Transferência de Trabalho". É, então, daquele que recebe a função de "mais um", o papel de revelador dos efeitos de transferência, emergentes durante o trabalho.

A transferência, como se sabe, é a estrutura do encontro entre sujeitos imersos em diferentes situações sociais. A diferença entre sua existência nos diversos contextos da vida cotidiana e sua existência no cartel (como na análise) é que, aí, deve ser reconhecida. Seu reconhecimento é condição necessária na passagem por sucessivos discursos, tanto no sentido de um "progresso", quanto, em alguns momentos, como "retrocesso". Sendo assim, o discurso analítico, que deve emergir do cartel, é incompatível à noção de grupo, pois, propondo-se a cercar o real, evidencia a passagem de um discurso a outro, impedindo que o efeito de 
grupo se consolide. Portanto, o cartel funciona como um instrumento de propagação dos efeitos do discurso analítico, pois, dá condições de que o grupo se desvencilhe do efeito de permanência própria de toda instituição.

Em Psicologia de Grupo e Análise do Ego, escrito entre 1919 e 1921, trabalhando com a idéia de sugestão, Freud já revelava questões sobre os efeitos de grupo. Apoiando-se em autores como Le Bon e McDougall, afirma que os grupos se distinguem por sua especial sugestionabilidade, isolandose, cada vez mais, da apreensão ou aproximação do real:

E, finalmente, os grupos nunca ansiaram pela verdade. Exigem ilusões e não podem passar sem elas. Constantemente dão ao que é irreal precedência sobre o real; são quase tão intensamente influenciados pelo que é falso quanto pelo que é verdadeiro. Possuem tendência evidente a não distinguir entre as duas coisas (Freud, 1988, p. 91).

Ao recusar os modelos e as imposições que caracterizaram a formação das instituições psicanalíticas durante um longo período, Lacan propõe um ensino que se pode qualificar de analítico. Pois, indica que o ensino da psicanálise só se dá de um sujeito a outro, pela função da palavra, pela via da transferência de trabalho. Não ocorre na imposição de um modelo, tampouco no sentido de percorrer os conceitos da teoria para o domínio de uma técnica. Como observa Voltolini "Cabe a Lacan o mérito de ter demonstrado que a economia da transmissão da psicanálise é mais complexa do que a economia de qualquer outra teoria científica" (2001, p. 1).

Também ao propor o passe, busca subverter o modelo de formação vigente, abolindo a clássica distinção entre análise pessoal e análise didática, ressaltando que uma análise pessoal somente poderia revelar-se didática a posteriori. Ao contestar os padrões de acesso à análise didática, existentes em quase todas as sociedades psicanalíticas ligadas à IPA, instituiu um regulamento que não mais obrigava os candidatos a escolherem seus didatas numa lista preestabelecida de titulares.

O processo era assim: o candidato ao passe (chamado passante) tinha de fazer um depoimento sobre o que fora sua análise perante dois analistas (chamados passadores), estes encarregados de transmitir o conteúdo desse testemunho ao júri de credenciamento. Esse júri era composto por membros eleitos pela assembléia geral da EFP [Escola Freudiana de Paris] e que já tivessem recebido o título de AE [analista da escola] 
O candidato em condições de receber o passe seria aquele que, em sua análise, conseguiu alcançar uma verdadeira mudança subjetiva, traduzida por uma mudança de desejo. A disposição ao passe revela uma relação de entusiasmo com os resultados da análise, uma "destituição subjetiva" (estado de perda, de castração ou até mesmo de depressão melancólica) e a "queda do sujeito suposto saber", da suposição de onipotência na figura do analista, da redução ao mínimo das identificações, um sujeito colocado ao abrigo das paixões coletivas. Condições contidas na idéia do "des-ser" e expressas, seja após a aquisição de uma técnica correta, seja após o reconhecimento da verdade da contratransferência.

A despeito de um propósito inverso, mesmo na situação do passe, é percebida a insistência de um caráter autoritário do didata em relação ao candidato. Nas assembléias da EFP de 1978, o fracasso do passe se revelou para o próprio Lacan como um "impasse", como efeito da massificação do lacanismo (idem, p. 577). Mesmo assim, ele é identificado como uma tradução possível do ponto de encontro (quando se deseja ocupar a posição de analista) ou da diferença (quando não há a demanda pela autorização) que Lacan apresenta entre o ensino psicanalítico em intenção (formação para o trabalho clínico) e em extensão (as conexões com os outros campos do saber). Resumidamente, a psicanálise em intenção conjuga o ensino da teoria e a formação de analistas, enquanto a psicanálise em extensão caracteriza a contribuição psicanalítica no diálogo com outros saberes.

Lacan conservou a expressão psicanálise didática para demonstrar uma inversão no modelo institucional: para ele, a ordem institucional representada por uma hierarquia, isto é, a psicanálise em extensão, devia estar submetida ao primado da teoria, presente na psicanálise em intenção, evitando que a teoria estivesse arriscada pela esclerose da burocracia nas instituições. A psicanálise em intenção poderia ser então considerada o "antídoto" de combate às distorções e enrijecimentos próprios às instituições e contrários à natureza da teoria psicanalítica.

Assim, a Ata de Fundação da EFP coloca a questão da relação entre 
uma escola (de formação) e um ensino da psicanálise. Tal escola comporta um ensino e um trabalho analítico, já que é a clínica que ensina o que pela teoria se tenta ensinar. $O$ que habilita a afirmação de que o analista inventa (psicanálise), cada vez, em sua própria clínica e aprende a partir dela. Também, de que o desenvolvimento do analista não está apoiado nos controles externos, mas na relação com a verdade e a capacidade de suportá-la, através da análise pessoal. Por isso é que a psicanálise acaba sendo considerada, por muitos autores, como intransmissível.

A afirmação de que "o analista não se autoriza senão por si mesmo" põe em questão o poder resolutivo da instituição, tirando-lhe o lugar de inteira responsabilidade pela formação. Isto não significa a supressão da formação, tal como muitos interpretaram, mas deixa ao próprio analista o poder de decisão sobre a autorização de sua prática. Apesar desse esclarecimento, Safouan (1996) manifesta sua preocupação em relação ao fato de que muitos se autorizam apenas pelo enunciado de Lacan, abrindo portas para a transgressão. Assim, o autor se mostra favorável à continuidade das sociedades psicanalíticas, uma vez que quanto menos dispensamos a lei, seja ela tradicional, revolucionária ou assim imaginada, "mais vacilante é nossa relação com uma outra lei que, por sua vez, não se deixa transgredir: está no próprio fundamento do desejo, mesmo considerado em sua face transgressiva" (Safouan et alii, 1996, p. 27).

Um sinal evidente de que um candidato ainda não se autoriza à prática seria sua demanda por um controle. $\mathrm{O}$ controlador é quem permite ao candidato analisar seu desejo de ser analista. Portanto, "a arte do controlador é permitir esse complemento indispensável para que o desejo de ser, de ser analista, esclareça-se à luz dessa figura ideal, que se origina em Freud, na qualidade de pai da psicanálise" (idem, p. 51).

A única razão que justifica a constituição de uma sociedade psicanalítica é que o candidato não poderia, sozinho, responder as questões colocadas pelo inconsciente. Isto porque, toda sociedade psicanalítica deve estar organizada, essencialmente, numa distinção entre os diferentes lugares da fala. Além de que, seus métodos devem obedecer a condição de não serem transformados em prescrições.

Até certo ponto, o que garante que se mantenha a essência das 
instituições psicanalíticas é a constatação que fazem Safouan e seus colaboradores,

Não são as pessoas que fazem a lei da organização, mas o contrário. Só uma organização, cuja lei se sustenta sem a relação dual que mantém o discurso do mestre, pode prosseguir o que já foi inaugurado na experiência analítica: contar pelo menos até três (ibid., p. 63).

A transmissão da psicanálise se produz numa relação a três desde os seus primórdios: Breuer era o professor ao qual Freud cultivava uma grande admiração e que, como aluno, Freud foi colocado na posição de controlador no tratamento de Anna O..

Uma longa história de oposições e rompimentos, muitos deles marcados pelo ódio e pela violência, fez proliferar segmentos, escolas, sociedades, dentre numerosas instituições no mundo todo que se propõem responder a uma única pergunta: como regulamentar institucionalmente a conquista de um saber inconsciente? Após o fim da Segunda Guerra Mundial, viu-se desfeito o sonho (expresso por Eitingon ${ }^{42}$ ) de um comitê internacional que fixaria regras de formação comuns entre as sociedades de diferentes países.

A Associação Psicanalítica Internacional tentou assegurar uma institucionalização e, há tempos, vem recebendo críticas que recaem sobre alguns aspectos: seus critérios de seleção, defrontados com a ausência de determinação sobre uma pretensa aptidão; rigidez das formas de ensino, semelhante às escolares; indefinição sobre o fundamento da análise de controle, na contratransferência ou na técnica; sobre a especificidade da análise didática em relação à convencional.

$\mathrm{Na}$ teoria não há nada que assegure a transmissão da experiência

\footnotetext{
42 "O ciclo de formação de um candidate deve se inscrever num esforço coletivo e engajar responsabilidade da associação regional da qual depende o candidato. Com esse objetivo, dever-seiam criar, em cada país, instituições adequadas, que funcionariam segundo os mesmos critérios e teraim a mesma organização, levando em conta diferenças locais. Por isso, parece-nos judicioso que a Associação Psicanalítica Internacional fixe diretivas que imponham uma autoridade geral" (In Safouan et alii, 1996, p. 92).
} 
psicanalítica, porque o desejo não pode ser institucionalizado. Como observou Micheline Enriquez: "Neste nó górdio, a coisa analítica encontrou a coisa institucional, ou, mais precisamente, o reconhecimento do desejo (...) se vê confrontado ao desejo de reconhecimento (...)" (1994, p. 16).

Noutra perspectiva, ao mesmo tempo em que a posição do saber no discurso analítico instaura a necessidade da instituição analítica (sociedade formadora), a própria situação didática é que põe em perigo as mesmas possibilidades de transmissão da teoria, pois carrega em si os germes do academicismo e da destruição do que the cabe transmitir.

Safouan (1996) sintetiza os entraves da institucionalização da formação psicanalítica no termo "obscurantismo" e, a partir dele, faz conhecer o "mal-estar da psicanálise". O referido mal-estar tem sua origem na especificidade mesma da transmissão psicanalítica. Se o ensino e a aprendizagem, em geral, estão apoiados num saber teórico cuja transmissão é garantida pelos antigos que guardam certo saber, no caso da psicanálise, a transmissão não se garante da mesma maneira.

"Uma prática estranha, marginal e atópica" (Safouan, 1996, p. 9), a psicanálise se funda no saber inconsciente, um saber não "didatizável", mas resultante de uma experiência pessoal que não depende de critérios terapêuticos. Isto porque, enquanto os métodos de seleção e de reconhecimento adquirem uma antigüidade passível de constituir um saber cujos antigos comportam, tal como os professores da universidade, por sua vez, uma experiência é sempre atualização.

A conclusão a que se chega em relação aos problemas da formação institucionalizada, segundo Safouan, já foi antecipada por Hanns Sachs, quando diz que toda organização visa a perpetuação da sua existência, portanto, é auto-conservadora. Sendo assim, além de não comportar a atualidade da experiência do candidato, também "tolera mal os espíritos criadores e a pesquisa que sempre vai na dianteira do novo" (idem, p. 16). Diante das tendências inerentes às instituições, progressivamente mais conservadoras, dirigidas para objetivos práticos e para sua sobrevivência, em 1939, Sachs já percebia que as pesquisas em psicanálise se encontram isoladas e afastadas das sociedades.

No entanto, as críticas que a instituição psicanalítica recebe não 
invalidam a função de terceiro que esta exerce, o que os psicanalistas reconhecem como "dimensão triangular do tratamento". O terceiro institucional desempenha a função de refrear o "poder totalitário do analista", portanto, trata-se de uma autoridade necessária e que, segundo Safouan (1996), reside no nome de Freud.

Entretanto, para além de toda polêmica: "A sociedade e a transmissão são possíveis porque as palavras têm um valor tal que dizer alguma coisa é dizer alguma coisa que se crê verdadeira ou que se quer que o ouvinte creia verdadeira" (ibid., p. 30). A psicanálise, como um terceiro, recupera o sentido (perdido) da educação, na medida em que o educador aí encontra um "outro ouvido" (Voltolini, 2001).

\title{
O ensino da psicanálise: estilo e invenção
}

\begin{abstract}
Isto se relaciona, sem dúvida, ao fato de que, em geral, é tão difícil proporcionar a quem não é psicanalista uma compreensão interna (insight) da psicanálise. Os senhores podem acreditar em mim, quando lhes digo que não é de nosso agrado dar a impressão de sermos membros de uma sociedade secreta e de praticarmos uma ciência mística. Mesmo assim, temos sido obrigados a reconhecer e a expressar nossa convicção de que ninguém tem o direito de participar de uma discussão sobre psicanálise, se não teve experiência própria, que só pode ser obtida ao ser analisado (Freud, [1933] 1994, p. 74).
\end{abstract}

Nessa citação, extraída de um texto apresentado sob a forma de conferências nunca proferidas, Freud busca transmitir a psicanálise no mesmo estilo analisado anteriormente (que designa por método genético), a um público imaginário, não pouco exigente e questionador. Inicia por "Isto se relaciona..." no esforço em definir o que, do funcionamento psíquico, especialmente o mecanismo de repressão, pode ser da ordem da consciência e o que pode ser inconsciente. Em outras palavras, Freud tentava delinear o que escapa ao sujeito e que, por isso, fala sobre ele mesmo. Em última instância, Freud diz que seu ensino não pode ser aprendido, mas, experimentado. Portanto, afirma que o conhecimento psicanalítico se dá apenas através do contato com o próprio inconsciente.

A convicção que Freud declara ecoa nos textos de autores 
psicanalistas da atualidade: "Como pensarmos, então, a transmissão da psicanálise? Se ela só tem um meio, a fala do analisando, a transmissão só existe na cura, ou seja, num percurso de análise" (Passos, 1991, p. 66); "...não há saber sobre o inconsciente que possa ser transmitido, mas um saber do inconsciente a ser construído em análise" (Ferreira, 1998, p. 130). A necessidade da análise pessoal na transmissão da psicanálise vincula-se ao fato de que sua compreensão está necessariamente condicionada ao acesso ao inconsciente do aprendiz, o que Freud denomina no trecho acima de compreensão interna. Dessa forma, supõe-se que o ensino acadêmico não esteja habilitado para realizar essa transmissão, já que está preparado para evitar efeitos não previstos nos planejamentos dos cursos. Essencialmente, os efeitos de transferência.

Se interpretadas "ao pé da letra", essas afirmações invalidariam o propósito desta pesquisa, isto é, chegaría-se à conclusão, portanto, que a psicanálise não poderia ser transmitida a educadores. No entanto, é necessário compreender que as palavras desses autores estão apoiadas numa concepção psicanalítica da transmissão como ato (o que produz efeitos). Surge daí outra convicção: não há transmissão sem efeitos. Mesmo que, submetida à "esclerose burocrática", a transmissão acadêmica da psicanálise pretenda o mesmo controle e prevenção de seus efeitos, parece ser esse um empreendimento de difícil realização, até mesmo, uma idéia totalmente contrária ao próprio fundamento da teoria psicanalítica. Os efeitos de uma transmissão (a transferência aí desencadeada) não são passíveis de serem evitados ou controlados. Por outro lado, emprestando a definição de Lacan, apenas no contexto da psicanálise em intenção, tais efeitos são interpretados e atualizados.

Diferente do que se percebe no discurso universitário, no contexto analítico, os efeitos não são somente previstos, como são "ferramentas" necessárias para o desenvolvimento da teoria.

... é mediante a experiência [da análise] que faz da eficácia de seu próprio inconsciente que o futuro analista se capacita a escutar e a poder compreender algo que the dirão futuros pacientes, no registro propriamente psicanalítico. (...) $O$ que caracteriza o processo psicanalítico como tal, portanto, é o movimento de desvendamento da gênese de um trajeto inconsciente, trajeto cujas etapas haviam sido 
percorridas em silêncio: silêncio do próprio inconsciente, avesso das ruidosas manifestações a que denominamos "sintomas" $e$ "resistências" (Mezan, 1988, pp. 169-170).

Diante dessas duas situações distintas na transmissão da teoria psicanalítica, ensino com finalidade de formação de analista e ensino aplicado a outros contextos, retorna uma questão levantada por Piera Aulagnier: "Qual é a relação que esse saber deve (ou não deve), pode (ou não pode) dividir com as disciplinas compreendidas sob o termo genérico de ciências humanas...?" (1990, p. 41). De forma breve, a resposta proposta neste trabalho seria de que a educação se "beneficiaria" de uma torção que a psicanálise produziria em seu discurso.

Antes de esmiuçar a idéia anterior, vale atentar para uma questão que pode ser colocada da seguinte maneira: como ensinar o que a psicanálise ensina? Ou ainda: como transmitir o saber psicanalítico?

Poderia se perguntar, como o faz Mezan, se há a possibilidade de um ensino psicanalítico da psicanálise, neste caso, segundo ele, partindo da compreensão de que o professor, assim como o analista, situa-se na condição de outros da constituição psíquica do aluno, tal ensino consistiria em remeter o sujeito às determinações que o governam e que engendram a ilusão transferencial. Nesse caso, haveria uma substituição insidiosa das figuras de professor à do analista, "substituição tanto mais grave quanto, no próprio ato de apontá-la, o apontador a confirmaria, usurpando assim um lugar que não é seu" (idem, p. 173).

Mesmo sabendo que o fundamento do encontro educativo reside no vínculo emocional que a psicanálise designa por transferência, o emprego da transferência como revelador do inconsciente não é objeto dessa "relação"43, podendo, na maioria das vezes, passar despercebida ou, quando mal empregada, manter indefinidamente ou violentamente os efeitos de poder.

A transmissão da psicanálise não depende da redução ao modelo da análise pessoal, pois o saber não está distribuído do mesmo modo nessas

\footnotetext{
43 As aspas indicam o distanciamento da concepção de relação professor-aluno numa perspectiva pedagógica, que a compreende como simétrica (causa e efeito). A psicanálise não pensa a relação da mesma forma. Esse tema foi desenvolvido na dissertação de mestrado da presente autora, intitulada $A$ Transferência e a Ação Educativa, apresentada à Faculdade de Educação da USP, em 2000.
} 
duas situações:

O psicanalista nada sabe, a priori, acerca do inconsciente de seu paciente (...). Tal saber irá se constituindo durante o processo analítico (...) o professor dispõe de um conhecimento que pode ser compartilhado (...) o saber preexiste à relação, ainda que possa ser modificado ou ampliado por efeito da própria relação (ibid., p. 174).

À frente de seus alunos, o professor possui conhecimentos que, na condição de saberes estabelecidos por antecedência, podem ser transmitidos e partilhados. Segundo Lajonquière, mais do que poder, ensinar é seu dever. Dívida adquirida na sua filiação a uma ordem simbólica, a uma tradição.

... conhecimento, saber, desejo e dívida simbólica se pressupõem e se articulam em toda a educação. (...) O aprendido é sempre emprestado de alguma tradição que já sabia o que fazer com a vida. (...) Dessa forma, como todo mestre foi algum dia aprendiz, ele não passa de um devedor (1999, p. 173).

Lacan considera que, através das instituições e dos textos, Freud obteve, até certo ponto, uma conservação puramente formal de sua mensagem, à medida que, tomada simplesmente por uma teoria, produziu a impressão errônea de um feixe finito de conhecimentos. Por outro lado, parece não haver dúvidas de que a teoria permanece necessária, mesmo na formação de um analista. Isto quer dizer que a psicanálise não se apresenta exclusivamente como experiência. Apesar das reconhecidas complexidades, também se encontra sob a forma de um currículo formal, que representa a condição para o diálogo com a cultura em seus diversos recortes.

O ensino da psicanálise, como se observa, apresenta uma constância: procurar refazer o caminho da gênese do texto, a fim de tornar claros seu conteúdo e seu desenvolvimento. Isto se deve a alguns aspectos do conjunto da obra psicanalítica: sua vasta extensão, seu acesso dificultado por razões de tradução, sua intrincada articulação e a existência de diversas escolas psicanalíticas. Diante disso, no papel do professor que ensina psicanálise cabe: acolher os percalços na aquisição dessa ferramenta e ampliar sua própria leitura, a partir dos resultados da leitura do aluno, sensibilizando-o para as múltiplas possibilidades de sentido que encerra o 
escrito psicanalítico (Mezan, 1988, p. 181).

Obviamente, como os próprios psicanalistas fazem questão de salientar, o conhecimento psicanalítico dá-se através de um lento amadurecimento no interior da pessoa e não estaria concluído ao final de um período letivo. Isso, no entanto, não impede que o aprendiz seja atingido pela psicanálise num contexto acadêmico. Juan-David Nasio, psicanalista renomado, teve seu primeiro contato com a psicanálise através das palavras, do estilo, de um transmissor, Arnaldo Rascovsky: "Imediatamente, como se acabasse de ser picado por uma agulha, fui subjugado pela eloqüência de um professor que ensinava psicanálise" (Nasio, 2001, p. 94).

Definindo seu estilo de transmissão como uma mistura de rigor, preocupação e dramatização, Nasio afirma que transmite o prazer que tem na transmissão, isto é, não somente transmite o saber como "transmito o prazer de transmitir o saber, de ensinar o saber" (idem, p. 94). Cada experiência de transmissão, diz Nasio, é única na forma de ensinar um saber, de despertar o entusiasmo pela psicanálise. Em consonância com o que foi exposto, Nasio diz que a diferença entre a transmissão da psicanálise e a formação do analista se resume ao fato de que o analista é formado na própria experiência de análise.

Pela via do ensino universitário, a contribuição psicanalítica à educação parece resultar em duas perspectivas: uma contraproducente, a psicanálise, transmitida sem estilo, é adulterada moldando-se ao discurso universitário e tornando-se um conjunto estéril de conceitos a serem proferidos e reproduzidos sem enganos e sem efeitos; outra, coerente com os propósitos psicanalíticos, passaria a operar na educação outra concepção de transmissão, porque se pensaria noutro sujeito e noutro saber no cerne do ato educativo.

Estabelecendo relações entre os discursos (analítico, universitário, do mestre e da histérica), Lacan não demonstra receios diante da abertura do discurso analítico aos demais discursos. Apostava na possibilidade do discurso analítico habitar a universidade sem prejuízos para si ou para as práticas universitárias, mais ainda, acreditava que essa conexão possa ser frutífera a ambas (Elia in Albert; Elia, 2000, p. 34).

Complementando essa aposta com as palavras de Kupfer: 


\begin{abstract}
...existe um saber da psicanálise formado por categorias que precisam ter uma coerência interna e que está do lado do pacto simbólico, do discurso social, das categorias científicas; nesse saber o real está recalcado. Por isso, transmitir a teoria psicanalítica não é o mesmo que entregar-se à livre associação; quem o faz estaria afirmando que o único saber possível para a psicanálise é o saber inconsciente. Esquecem-se de que, quando a exigência é de transmissão, temos que nos curvar ao que não é equívoco nem mal-entendido. (...) O modelo de transmissão da psicanálise está longe de ser um sonho! Então, a transmissão da teoria psicanalítica pode ser feita na universidade no segundo grau, na instituição psicanalítica, produzindo os efeitos subjetivantes de qualquer teoria que fale do sujeito (2001, p.122-3).
\end{abstract}

Para que se realize a esperança de Freud, a saber, de que o estudante aprenda algo sobre psicanálise e que aprenda algo a partir da psicanálise, impõe-se a necessidade de que esse ensino não apresente a teoria como dogma, mas que ela seja apresentada ao estudante, para além de um conhecimento objetivo, como uma experiência. O que aqui é expresso por "necessidade" não remete a alguma técnica a ser dominada, mas um resultado do mestre atravessado pela psicanálise.

O dogma é veiculado por "guardiões" que arbitram sobre a verdade, caracterizando uma transmissão pautada no prestígio e na censura. Por isso, enquadra-se no critério universitário, de currículo e programas definidos. Na transmissão compreendida como ato, o saber não é sabido por alguém, mas é suposto no lugar de alguém. Retorna, portanto, a discussão sobre o discurso do mestre, lugar onde o escravo atribui o saber. "Não esperem portanto de meu discurso nada mais subversivo do que não pretender a solução" (Lacan, 1992, p. 66). Não declarando aquilo que demandavam os estudantes universitários (um saber na dimensão positiva), Lacan recusa dar à sua fala, à palavra, o estatuto de verdade.

O ensino da psicanálise não pode ser pensado como um mero acréscimo no campo epistemológico, nesse ensino se transmite uma outra coisa, mais próxima de uma subtração: da certeza. "A coerência que ela [psicanálise] mostra é radicalmente nova, pois está particularmente afetada de um sinal negativo, dado o fato de dar conta das condições pelas quais um sujeito alcança a medida de sua própria ignorância" (Enriquez, 1994, p. 16).

Obviamente, quando não se fala do lugar de "mestre" (detentor do saber absoluto), o ensino da psicanálise produz efeitos e (dependendo, 
também, do lugar do aprendiz) configura-se num ato. Por isso, para que a transmissão seja fiel à teoria, o sujeito que transmite permanece num determinado campo ético, fundamentalmente, isento da posição de tudosaber. E, tendo sofrido os efeitos da experiência com a psicanálise, produz seu (um) estilo. A transmissão é, portanto, estilo e ética.

Os efeitos da transmissão são precários, porque dependem de como esta transmissão é recebida; ela não é uma mensagem positiva - é muito mais em negativo - é alguma coisa que foi cavada. (...) No nosso caso, é nitidamente retirando-se que se chega a alguma coisa, a um estilo (Barros, 1999, p. 34).

Percebendo as distorções a que a teoria psicanalítica estava sujeita no momento de sua expansão (no interior da discussão sobre a análise leiga, na exclusão de Jung e Adler da psicanálise), Freud funda uma Associação Internacional na intenção de que ela garantisse a transmissão da psicanálise, preservada em seus princípios básicos. Por isso, mesmo revestida das esperanças mais elevadas pelo "bem-fazer", a ânsia pelo(s) modelo(s) na transmissão já causaria danos ao ensino da psicanálise, como foi exposto nas páginas anteriores.

Traduzida em infinitos estilos, a transmissão da teoria psicanalítica encontra uma única perspectiva para manter-se afastada do aprisionamento representado pelo modelo institucional de ensino: alimentar o questionamento. Essencialmente um questionamento do ensinante sobre qual desejo ele responde ao aceitar estar nesse lugar e, assim, até certo ponto, colocar-se ao abrigo “... das armadilhas de sua própria fala, da fascinação própria à posição do sujeito suposto saber e, portanto, do uso que ele pode fazer disso" (Aulagnier, 1990, p. 43). Aprender psicanálise não pode ser equivalente a receber o resultado de um processo de reflexão, sob sua forma conclusiva, mas tornar-se apto a reavivá-lo num permanente processo de reflexão. Isso também implica em dizer que não se ensina "pensar psicanaliticamente", ou melhor, mais do que resultado de um ensino, trata-se aí de um efeito da transmissão. Logo, é necessário que, além de possuir familiaridade com a literatura psicanalítica, exista uma atitude de investigação que evidencie que o professor se desvencilhou do dogmatismo.

O lugar que o saber ocupa na transmissão da psicanálise produz 
estilos como o de Freud, predominantemente contrário ao dogmatismo (sobre o qual se debruça o início deste capítulo), e o de Lacan, que se privava da posição de Amo, como é possível verificar nos seminários que realizava na universidade: "Se começasse como sempre tenho vontade, seria de forma abrupta. É por vontade que não o faço, vou habituando vocês, evitando-Ihes choques" (Lacan, 1992, p. 67).

Desde Freud, a transmissão da psicanálise na formação de psicanalistas, em última instância, repousa na transmissão de estilos. O que não significa dizer que há aí uma reprodução. Aliás, sabe-se que, quando ocorre a cópia, o resultado torna-se desastroso.

A idéia de um estilo contraria a ânsia de toda empresa pedagógica pelo modelo mais adequado de transmissão. O modelo, ou padrão, como se pode ver, é a própria rejeição do estilo. Mais ainda, pode-se afirmar, a partir da análise realizada neste texto, que o mestre absoluto não tem estilo.

Recorrendo à leitura de Lacan, Kupfer menciona uma curiosa acepção do termo estilo:

\footnotetext{
Um estilo pode ainda ser um vaso. Na Antiguidade alguns povos modelavam grandes recipientes de cerâmica e lá guardavam os documentos em que estavam registradas suas leis. Lacan diz que nos estilos uma cultura guardava seus tesouros... Os estilos são de fato tesouros do sujeito, que muitos deles desconhecem possuir. Nossa árdua tarefa será então a de ajudar, remando contra a maré de muitos discursos sociais cada aluno a desenterrar o seu próprio tesouro (2001, p. 132-3).
}

\section{Lacan e Laplanche na universidade}

Em 20 de novembro de 1963, graças a Louis Althusser, Lacan instalase na École Normale Supérieure, na seção da Escola Prática de Altos Estudos, onde dá continuidade aos seminários que vinha proferindo no Hospital de Sainte-Anne ${ }^{44}$ e para as sucessivas instituições psicanalíticas.

\footnotetext{
44 "Se tivesse que interpretar o que dizia em Saite-Anne entre 1953 e 1963, quero dizer, anexar-lhe uma interpretação num sentido contrário à interpretação analítica, que faz perceber bem o quanto a
} 
Contexto diferente dos dez anos anteriores, quando o público era predominantemente composto de psicanalistas (os "pilares" da Escola Freudiana), agora, no entanto, são os profissionais da medicina que ouvem $\operatorname{Lacan}^{45}$.

No período entre 1945 e 1968, introduzida originalmente por Daniel Lagache $^{46}$, a Psicanálise na universidade era ensinada sob o rótulo de psicologia, numa linha mais próxima ao trabalho de Janet ${ }^{47}$ do que da teoria freudiana.

A partir de outubro de 1968, ocorre uma reorganização na inserção da psicanálise na universidade, dando origem a duas experiências distintas: uma essencialmente voltada para a psicologia clínica (Censier - Paris VII), na qual permanece a herança deixada por Lagache; outra, conduzida por Jacques Lacan, com o primeiro Departamento de Psicanálise, na Universidade de Vincennes - Paris VIII, quando pela primeira vez o ensino universitário da psicanálise se apresentou desligado de qualquer subordinação à medicina e à psicologia (diferente, portanto, de Paris VII e V, essa última, experimentalista).

O campus de Vincennes ficou conhecido como um dos pilares do movimento estudantil de dezembro de 1968, na França, rico em acontecimentos, explosões e inovações. Nele, o Departamento de Psicanálise se insere num contexto de formação filosófica e literária, em que se abordam vários temas, que giram em torno da história, do discurso psicanalítico, da lógica do inconsciente ou da clínica.

Como se pode ler nos documentos de divulgação dessa universidade, o Departamento de Psicanálise "tem uma missão de ensino superior e de pesquisa”, e visa transmitir tanto os saberes que emanam da experiência

\footnotetext{
interpretação analítica está, ela própria, na contramão do sentido comum do termo -, diria que o mais sensível, o tom que verdadeiramente predominava, era a gozação" (Lacan, 1992, p. 15).

${ }^{45}$ Apesar de boa parte de esses psicanalistas terem a medicina como formação anterior.

${ }^{46}$ Daniel Lagache $(1903$ - 1972), psiquiatra e psicanalista francês, pertencia à segunda geração de psicanalistas franceses, herdeiro das concepções de Janet e introdutor da psicanálise na universidade, opôs-se aos que preconizavam o vínculo da Psicanálise com a medicina e a Lacan, que queria desvincular a Psicanálise da psicologia (Roudinesco; Plon, 1998).

47 Pierre Janet (1859 - 1947), médico e psicólogo francês: "Teórico do automatismo psicológico [funcionamento espontâneo da vida psíquica, compreendido numa visão organicista e hereditária] e fundador na França da corrente da análise psicológica, Pierre Janet foi, como Theodore Flournoy e Sigmund Freud, seu grande rival, um dos principais artífices da segunda psiquiatria dinâmica. Até 1915, seus trabalhos foram mais célebres que os de Freud, comentados no mundo inteiro por todos os especialistas em doenças nervosas" (idem, p. 407).
} 
psicanalítica quanto os que são conexos, já que "o saber freudiano não é redutivel a um corpo de doutrina fechado e definitivamente constituido" (Alberti, 2000, p. 8).

Os conflitos que caracterizam Vincennes alcançam o Departamento de Psicanálise, onde os desentendimentos em torno da questão das exigências administrativas da universidade têm em Lacan um contestador e em Leclaire (seu discípulo) um consentimento baseado no imperativo de penetração da "subversão lacaniana" na universidade.

O terceiro deslocamento de Lacan dá-se quando, expulso da École Normale Supérieure (ENS) em março de 1969, transporta seu seminário para a Faculdade de Direito. Expressa, no Seminário 17, seu interesse em que os estudantes de Direto participem de suas conferências, já que, tratando do Avesso da Psicanálise, considera esse o tempo mais importante dos três deslocamentos, dado o seu estatuto no sentido chamado jurídico do termo.

Como foi tratado em páginas anteriores, Freud ressalta um modelo de ensino que, sob a classificação de método genético, caracteriza-se pelo reconhecimento do espaço da irracionalidade e das objeções à elaboração do comunicador. Além de consistir num procedimento de reconstituição, junto ao público, de toda via de investigação percorrida, há um apelo de que o julgamento se mantenha suspenso, para deixar que o assunto aja sobre $o$ ouvinte.

Consciente das resistências de um público habituado ao discurso universitário (essencialmente dogmático) e desconfiado das inovações, Lacan situa seu ensino. Primeiro, reconhece a posição de prestígio de quem ensina e prevê o risco de que aquilo que enuncia caia sob a ação do discurso universitário, através de uma postura refratária. Portanto, chamando de desaprumo fundamental, declara não se identificar com a posição de prestígio e, tampouco, se reveste da permissão de dizer qualquer coisa (impensadamente). De maneira bastante semelhante ao mestre, pede ao público que the conceda algo de "uma ordenação que me impõe o dever de pôr à prova esse trilhamento" (Lacan, 1992, p. 40). Depois, declara estar à espreita da contestação, sobre a qual manifesta grande interesse, por considerar que ela venha confirmar ou desmentir o nível em que se situa a 
estrutura de um (seu) discurso.

\begin{abstract}
Não creio que contestar seja perturbar uma aula. Seria um infortúnio que eu tivesse que ensinar isto à própria contestação.

$\mathrm{Na}$ verdade, igualmente essencial ao fato de que eu fale ou não tranqüilamente é aquilo em que estão imersos os que me escutam. $O$ que estou falando assinala, de fato, a entrada em ação desse discurso que não é o meu, mas sim aquele de que sou, para me ater a este termo provisório, o efeito (idem, p. 22).
\end{abstract}

Lacan relata sua experiência em Sainte-Anne, quando, certa vez, ao começar sua preleção, foi realizada uma pesquisa a fim de verificar se seu ensino respondia bem às garantias do que constitui um ensino médico. Temia-se que não e "foram convencidos de que eu os havia metido na triste necessidade de suportar, no âmago de um lugar essencialmente médico, um ensino que não o era" (ibid., p. 23). Para concluir que seu ensino exala um efeito de incômodo, relata também sua experiência na Escola Normal cujo incômodo "revestiu-se" de uma fumaça que impedia a leitura dos estudantes na biblioteca. Antes de terminar o segundo relato, um funcionário da Faculdade de Direito apaga as luzes e carrega o quadro-negro, obrigando Lacan a suspender seu ensino.

Reconhecendo-se fiel à teoria psicanalítica, Lacan compara Freud a Marx para explicar as resistências enfrentadas no contexto universitário. Ambos, segundo ele, não dizem besteira:

... ao contradizê-los, corre-se o risco de escorregar (...) na besteira. Eles desarrumam o discurso dos que querem enfrentá-los. Eles o petrificam com freqüência em uma espécie de recusa acadêmica retardatária $e$ conformista, irredutivelmente (ibid., p. 67).

Não dizer besteira se relaciona com admitir que o saber é coisa que se diz, que o saber fala por conta própria (eis o inconsciente). Por isso, Freud sustenta um discurso estranho ao contexto universitário, pois é contrário à "coerência" de um discurso: concebe a idéia de que o sujeito do discurso não se sabe como sujeito que sustenta o discurso. "O mito do Eu ideal, do Eu que domina, do Eu pelo qual alguma coisa é pelo menos idêntica a si mesma, a saber, o enunciador, eis precisamente o que o discurso universitário não pode eliminar do lugar onde se acha a sua verdade" (ibid., p.59). 
Acreditando que a verdade, mesmo no contexto universitário, não permite um acesso fácil, Lacan elabora a pergunta: o que é verdadeiro? Responde: a frase. Ela que não existe sem se sustentar no significante que, por sua vez, não concerne ao objeto, mas ao sentido. Como sujeito da frase, só há o sentido, isto é, o sentido é o que mais ser tem e, portanto, não pode deixar de existir.

Da definição do lugar da verdade e do sentido no discurso, Lacan se habilita a propor um modelo de ensino destituído da necessidade de saber absoluto, por isso, desde seus primeiros seminários sobre psicanálise faz recomendações ao público, tais como: não se preocupar em dizer coisas elegantes, como identifica nas comunicações ditas científicas; permanecer aberto às coisas inesperadas; colaborar para uma comunicação efetiva, através da participação, da contestação.

O efeito de seu ensino deve, segundo Lacan, ultrapassar o caráter de comunicação e configurar numa continuação da existência do ouvinte, daqueles para os quais os seminários têm pleno sentido.

Sendo consultado sobre as acusações que Lacan recebia de hermetismo e de "terrorismo intelectual", em entrevista com J. Nobécourt, Foucault remete o interlocutor aos efeitos e o, conseqüente, sentido do ensino de Lacan:

Penso que o hermetismo de Lacan é devido ao fato de ele querer que a leitura de seus textos não fosse simplesmente uma "tomada de consciência” de suas idéias. Ele queria que o leitor se descobrisse, ele próprio, como sujeito de desejo, através dessa leitura. Lacan queria que a obscuridade de seus Escritos fosse a própria complexidade do sujeito, $e$ que o trabalho necessário para compreendê-lo fosse um trabalho a ser realizado sobre si mesmo. Quanto ao "terrorismo", observarei apenas uma coisa: Lacan não exercia nenhum poder institucional. Os que o escutavam queriam exatamente escutá-lo. Ele não aterrorizava senão aqueles que tinham medo. A influência que exercemos não pode ser nunca um poder que impomos (1999, p. 299).

Analisandos de Lacan, Jean Laplanche e Jean-Bertrand Pontalis, por volta de 1958 e sob a direção de Lagache, iniciam a redação do monumental "Vocabulário de Psicanálise", que foi traduzido em mais de vinte línguas e admirado pelo rigor epistemológico. Na Unidade de Ensino e Pesquisa de 
Ciências Humanas e Clínicas (Sorbonne - Paris VII), Laplanche é o primeiro a introduzir oficialmente a palavra psicanálise, nos anos de 1969-1970, com a criação de um Laboratório de Psicanálise e Psicopatologia, que se organizava a partir de quatro eixos: Psicopatologia Psicanalítica, Psicanálise Aplicada, Teoria da Psicanálise, e História da Psicanálise e da Prática Freudiana.

Em 1974, Laplanche cria um diploma de estudos aprofundados (DEA) de Psicopatologia Clínica e Psicanálise, defendendo uma posição favorável à extraterritoriedade da psicanálise, isto é, na universidade, o ensino do freudismo, segundo ele, deve ser externo a outros campos, pois, até então, participava de um centro pluridisciplinar de ensino, apoiado essencialmente na psicologia clínica. Passados seis anos, o diploma adquire o nome de Doutorado em Psicanálise. Ambos os empreendimentos de Laplanche foram alvos de contestações. Dentre elas, do presidente em exercício da Sociedade Psicanalítica de Paris, ao que Laplanche argumenta:

Fora da peripécia, qual é, no entanto, o fundo? O fundo é que essa habilitação de um "Doutorado em Psicanálise" vem rematar algo perfeitamente novo na França, e talvez no mundo: a presença na Universidade de uma equipe de analistas, falando enquanto tais - não sob o abrigo de outra disciplina, Psicologia, Letras ou Filosofia - da análise, de forma autorizada, na Universidade (1993, p. 111).

Considerando a conquista do Doutorado como a confirmação da longa existência da psicanálise na universidade e o reconhecimento de um campo científico autônomo no qual contribuições cumulativas são possíveis, Laplanche recupera o significado de um Doutorado na universidade. Segundo ele, o trabalho de pesquisa (tese), que já exige experiência universitária de vários anos de estudo, não dá acesso a nenhuma qualificação profissional, não confere nenhuma capacitação para um exercício profissional, tampouco a de psicanalista, consiste, pois numa "simples peça de apoio num dossiê para postular eventualmente um cargo de ensino superior, aliás, sem qualquer garantia de obtenção" (idem, p. 110).

Fundador do Laboratório de Psicanálise e Psicopatologia, do Doutorado em Psicanálise em Paris II, criador da revista Psychanalyse à I'Université, diretor da editora Bibliothèque de Psychanalyse, Roudinesco 
observa no percurso de Laplanche "uma carreira magnífica para um aluno que recusou o mandarinato de seus dois mestres" (1988, op. cit., p. 599). Os mestres em questão são Lacan e Lagache.

Sobre o modo de se ensinar psicanálise, na perspectiva de Laplanche, nota-se uma convergência em relação ao exposto em Freud (com o método genético) e Lacan (com o sentido que o seminário produz). Seu conceito de ensino, num âmbito abrangente, não pode ser outra coisa senão o correlativo de uma pesquisa: o relato, a apresentação formal e, mesmo, lugar de elaboração. A psicanálise na universidade seria uma abertura para um ensino não dogmático, caracterizando a universidade como um lugar não limitado à rotina, a um repisamento enfadonho, a uma repetição, mas um lugar de descoberta. Nesse ínterim, critica o histórico de programas de formação nos Institutos de Psicanálise, cujo ensino, como considera, descambou para o didatismo e até para o dogmatismo.

Sobre a polêmica em torno da exigência da análise para que se possa participar da transmissão da psicanálise, Laplanche levanta uma crítica importante, com o intuito de recuperar a finalidade da análise como processo independente, atópico, não normativo, afirmando, mesmo, a sua existência que ultrapassa o espaço mais restrito da prática analítica:

O dia em que a análise se torne objeto de um certificado que outorga um direito - não como resultado de um processo mas como uma sanção puramente formal em decorrência de ter sido feita -, então trata-se de qualquer outra coisa menos de análise. (...) Renunciar a ensinar a análise a não-analistas, a não-necessariamente analistas como é o caso de vocês, (...) é renunciar a inventar, a reinventar incessantemente um modo de ensino que seja permeável à inspiração da análise, permeável ao inconsciente (1992, pp. 2-4).

A oportunidade de se falar da psicanálise no contexto universitário, na ótica de Laplanche, significa considerar a teoria como um conjunto de enunciados comunicáveis, passíveis de prova, discutíveis, e até mesmo eventualmente falsificáveis ${ }^{48}$, portanto, que não se possa falar qualquer coisa a partir da psicanálise. Seu ensino consiste em ler e comentar a obra freudiana, buscando divulgar amplamente a conceituação original.

\footnotetext{
${ }^{48}$ Portanto, contrário à afirmação de Popper.
} 
O que é, pois, levar em conta o pensamento do outro, em psicanálise particularmente? Com certeza é saber expô-lo sem traí-lo, e eventualmente expô-lo à crítica, tentando primeiro "compreender" (com todas as aspas necessárias) a inspiração do que foi dito. Isto lhes será exigido como exercício de validação desses cursos teóricos (Laplanche, 1993, p. 1).

Um método interpretativo e de resolução de problemas, eis como Laplanche define a estrutura de seu ensino. Seus cursos recebem um título geral: "Problemáticas". E sob esse mesmo título geral são reunidos os temas que compõem o conjunto de suas publicações. $O$ método de Laplanche permite que se faça perguntas ao texto, toma-se por uma intimidade com a leitura, fruto de um trabalho que respeita o andamento do pensamento do autor e atento às pegadas do processo da elaboração, permitindo que a leitura não se torne apenas recepção, mas trabalho, diálogo e criação.

Laplanche prevê duas possíveis reações em relação ao seu ensino: a primeira, um ataque a um suposto classicismo, um freqüente recurso ao comentário crítico, os retornos e as repetições; a segunda, mais receptiva, permite ao ouvinte acompanhar os aprofundamentos teóricos, a partir dos quais surgem lacunas nas articulações e, também, derivam certos conceitos.

O ensino da psicanálise na universidade, segundo Laplanche, apresenta dois sentidos combinados: a contribuição, o aspecto cumulativo de certos suportes teóricos; e a possibilidade de mostrar que certa trajetória, com erros, repetições e vacilações, pode contribuir para a tomada de consciência dos ouvintes: "... os estudantes freqüentam o 30 ciclo com a intenção primordial de 'ler Freud'. Isso é inteiramente legítimo, cada um deve fazer seu percurso em Freud, cada um deve, de acordo com a sua possibilidade, fazer o seu Freud" (1992). Idéia semelhante aos efeitos que Freud e Lacan prevêem e esperam da experiência do público com seus ensinamentos: um ensino permeável ao inconsciente, como Laplanche define em citação anterior.

Laplanche aborda a questão das repetições, distinguindo uma repetição pura (da qual acusa boa parte da prática na universidade) de outra em expansão. No percurso do desenvolvimento de um pensamento, do tratamento dispensado a um conceito, as repetições são previstas, mas, em expansão, desenrolam em planos que, apesar de tudo, mudam. Nessa linha, 
falar de psicanálise é sempre falar do inconsciente, no entanto, não implica que sejam formuladas as questões últimas sobre o ser, ou sobre seus fundamentos. Novamente, entende-se que um conceito psicanalítico não pode ser apresentado como um conhecimento fechado e acabado. Portanto, impossível de ser transmitido com fidelidade ou dignamente exposto por um ensino dogmático.

O questionamento sempre aberto sobre 0 que vem a ser a psicanálise, como se tentou praticar no segundo capítulo desta tese, parece ser fundamental à sua sobrevivência. Se uma ciência, uma epistemologia, uma ética, uma contraciência, uma arte ou uma visão de mundo, em última instância, a psicanálise tem desempenhado o papel de um significante. Propondo-se a revelar a verdade sobre como o sujeito se constitui, revela o sujeito e a verdade de seu desejo como impossíveis de revelação. A verdade escapa porque o desejo escapa, afastando a possibilidade de conhecimento direto e terminado sobre o sujeito.

A transmissão da psicanálise, para ser fiel à sua descoberta, assume a performance de uma arqueologia. Na exploração de um sitio arqueológico, o explorador escava, efetua fendas, buracos, encontra fragmentos de produções humanas, procura contextualizar tudo que se abre em frente a seus olhos. Sua tarefa, portanto, não se limita a uma descrição e catalogação, mas modificações em, pelo menos, dois pólos da história: aquilo que durante muito tempo esteve encoberto agora se transforma, não apenas pelos possíveis acidentes naturais ou técnicos, mas em seu significado, dentro de nova ordem social; por outro lado, o momento atual tem sua compreensão ("identidade") modificada por um fragmento de origem. A verdade se transforma, tanto pelo efeito do presente como pelas revelações do passado.

As mudanças operadas pelo discurso psicanalítico habilitam a afirmação de que ele não descobre a realidade, mas a cria. A psicanálise é, portanto, convocação à invenção.

Assim como a psicanálise se situa para além da descrição e controle 
da realidade, distante do modelo positivista da ciência, também a educação avança os limites delineados pelo discurso científico e pelo discurso universitário. Nessa constatação está apoiada a legitimidade e o imperativo de que a psicanálise seja ensinada aos educadores. 


\title{
CAPÍTULO IV
}

\section{UMA ESPECIFICIDADE NA FORMAÇÃO DE EDUCADORES}

\author{
"Os ensinamentos de Moisés passaram \\ por múltiplas mudanças $e$ \\ transformações; às vezes, pareciam ter \\ desaparecido completamente; outras \\ vezes pareciam ter se invertido e se \\ tornado exatamente o contrário. Mas, \\ após um longo lapso de tempo, a alma e a \\ essência de seus ensinamentos \\ reapareceram e se tornaram a força \\ diretriz de nossa porção do mundo \\ civilizado. Não parece improvável que a \\ descoberta de Freud do inconsciente e do \\ complexo de Édipo possa ter um destino \\ semelhante" (Safouam, 1996).
}

Subtrair a prerrogativa dos médicos sobre a psicanálise e desbravar novos terrenos para o avanço da "causa": duas perspectivas promissoras se abrem frente à aproximação da psicanálise com a educação. Um novo público, composto de professores e pedagogos, representou a possibilidade de mútua contribuição: a perpetuação da psicanálise e a pedagogia nutrida de uma "educação psicanalítica".

Numa conferência intitulada Psicanálise e Pedagogia, proferida na cidade austríaca de Salzburg, em 1908, Sandor Ferenczy questiona o caráter repressivo da educação e declara a pedagogia como produtora de neuroses. Foi dessa forma que se projetou o primeiro olhar psicanalítico sobre a educação, conservando o mesmo perfil durante longo período e deixando, ainda, fortes resquícios em produções mais atuais.

A psicanálise aplicada à educação é pensada inicialmente por Freud, de modo geral, como análoga à análise infantil. Concepção sintetizada nas palavras de Cifali e Imbert: "O singular sobrepuja o coletivo" (1999, p. 11). 
Educação e terapia são concebidas como complementares: "a educação deve ser profilática, ter como objetivo o impedimento da formação das neuroses, antes que a psicoterapia tenha que corrigir uma evolução mórbida através de uma ação desde já re-educativa" (Filloux, 1999, p. 11).

Pastor protestante que, em 1909, buscou na psicanálise um instrumento para entender a alma, Freud teve em Oscar Pfister ${ }^{49}$ o mais importante colaborador na tese de que uma pedagogia que levasse em conta as descobertas psicanalíticas proporcionaria melhor preparo da criança para uma vida não neurótica: "Deve-se ler aqui uma espécie de otimismo com a chegada de uma nova geração de homens, graças à psicanálise aplicada à educação" (idem, p. 11). Agindo na tensão entre "pulsão" e "cultura", a partir da tese freudiana, a escola teria condições de redimensionar seu papel de tornar o indivíduo apto para a cultura e socialmente produtivo, de maneira isenta da severidade inútil e da ausência de discernimento que a fez produtora de doenças nervosas ${ }^{50}$.

Em meio a um diálogo amigo e cordial que suportava com brandura as divergências entre o discurso psicanalítico e religioso, entre Freud e Pfister, prosperava um debate fecundo, que ultrapassava o campo pedagógico e alcançava questões sobre a ética, sobre visão de mundo e sobre a legitimidade do discurso científico.

Da esperança numa reforma da educação através de uma "Pedagogia Psicanalítica", as idéias de Pfister evoluem para um suposto promissor tratamento psicanalítico de alunos nervosos (desvios manifestos por: letras ruins, erros de cálculo, tiques e ódio), realizado por pedagogos informados sobre o funcionamento do inconsciente.

Até aí (aproximadamente 1920), muitas conferências de Pfister sobre a temática "Psicanálise e Pedagogia" já haviam sido publicadas e foram

\footnotetext{
${ }^{49}$ Nascido em 1873, doutor em filosofia e doutor honoris causa em teologia: "Entre 1909 e 1956, ano de sua morte, Pfister produz inúmeros livros e artigos em que expõe observações e resultados de pesquisas próprias, sobre tudo sobre a técnica do método psicanalítico, sobre o significado etiológico da sexualidade na construção das neuroses, sobre religião e histeria, psicologia da arte, filosofia e psicanálise, a cura analítica de almas (...), cristianismo e angústia, e temáticas relacionadas" (Prefácio de Heinrich Meng às Cartas entre Freud e Pfister, 1998, p. 14).

50 "Certamente, se a intenção dos educadores é sufocar a capacidade da criança de pensamento independente, em favor de uma pretensa 'bondade' que tanto valorizam, não poderiam escolher melhor caminho do que ludibriá-la em questões sexuais e intimidá-la pela religião. As naturezas mais fortes, é verdade, resistirão a tais influências e se tornarão rebeldes contra a autoridade dos pais e, mais tarde, contra qualquer outra autoridade" (Freud, O esclarecimento sexual das crianças, 1907).
} 
traduzidas para o francês por Pierre Bovet, diretor do Instituto Jean-Jacques Rousseau e professor da Universidade de Genebra. Abordando as concepções freudianas relativas à sexualidade infantil, Bovet depositava extrema confiança na proposta profilática e recomendava as idéias diretrizes da psicanálise a todos os professores.

Outro tributário desse projeto foi Hans Zulliger, que se tornou psicanalista ao conhecer Pfister. Com uma vasta experiência como professor em Zurique, Berna e Heidelberg, escreveu vários livros, dentre eles, o muito elogiado por Freud, A Psicanálise na Escola, de 1921, além dos vinte e um artigos para a Revista de Pedagogia Psicanalítica.

E, certamente, esse trabalho [Psicanálise na escola], resultante das primeiras experiências de um professor analisado, inspirado pelo conhecimento da psicanálise, o mais próximo da relação que ele mantém com seus alunos e seus problemas, fala incontestavelmente ao leitor de hoje. Defensor de uma "outra atitude" do pedagogo, atento à expressão dos alunos, a casos individuais, o livro é uma seqüência de capítulos apresentando cada um dos exemplos através de uma perspectiva analítica na relação do professor com sua classe (Filloux, 1999, p. 13).

Inicialmente exercendo certos tipos de "psicoterapias psicanalíticas" (entrevistas, redações, relatos de sonhos, organização de jogos ou encenações teatrais), Zulliger evoluiu, mais tarde, com a diferenciação entre a psicanálise infantil e a pedagogia psicanalítica, chegando a declarar que os novos métodos fundamentados na psicanálise poderiam não ser estritamente "analíticos".

Tal cenário novo e transformador que se abre à frente do precursor da psicanálise não tardaria a mostrar fortes limitações. A confiança numa profilaxia das neuroses a partir de uma reforma na educação logo se revela ilusória, à medida que se descobre uma etiologia da repressão divergente da idéia de exterioridade, isto é, não mais limitada à idéia de uma moral social avessa à sexualidade e por si só causadora de danos.

Paralelamente aos trabalhos de Pfister, Bovet e Zulliger, que alimentavam a esperança depositada na educação, Freud introduz novos conceitos em sua pesquisa, tais como a pulsão de morte (uma terceira força, além do princípio do prazer e do princípio da realidade) e o narcisismo, que culminaram numa nova compreensão sobre a estrutura do aparelho 
psíquico, e cada vez mais próximo da idéia de uma tendência constitutiva à repressão.

Muito antes, como se pode constatar desde 1896, Freud revelava em suas cartas a Fliess uma desconfiança de que a moralidade seria uma defesa contra um desprazer inerente à sexualidade. Configuram dentre suas hipóteses: a posição ereta adquirida pela civilização, que tornou repulsivas as sensações (as mesmas que antes despertavam interesse) proporcionadas pela proximidade entre os órgãos sexuais e excretores; e a bissexualidade (intensamente defendida e fundamentada por Fliess) que tornaria irrealizável a satisfação sexual plena. Em suma, procede daí uma inversão do problema: a repressão da sexualidade não tem origem na moralidade, mas o contrário, é a moralidade que advém da própria natureza da pulsão sexual.

No texto Três Ensaios sobre Sexualidade, de 1907, Freud já não considera a repressão como sendo inteiramente devida a influências sociais externas:

\footnotetext{
Tem-se das crianças civilizadas uma impressão de que a construção dessas barreiras [opostas ao instinto sexual] é um produto da educação, e sem dúvida, a educação muito tem a ver com ela. Mas, na realidade, este desenvolvimento é organicamente determinado e fixado pela hereditariedade, e pode ocasionalmente ocorrer sem qualquer auxílio da educação (1988, p. 167).
}

Diante de tais declarações, segundo Catherine Millot, pode-se afirmar que foi a descoberta da sexualidade infantil que veio lançar "uma nova luz sobre a natureza do processo educacional e impulsionou Freud a se ocupar desse problema" (1995, p. 164). Proporcionou um esclarecimento sobre a natureza da sexualidade humana e a reativação (um redimensionamento) da questão das relações entre sexualidade e civilização.

Cabe acrescentar a leitura de Lajonquière (2002) sobre os dois supostos momentos da aproximação de Freud com a educação. Na perspectiva do autor, não existiram dois "Freuds" em matéria de educação, mas um único propósito que se revela desde o princípio, a saber, a esperança em uma outra educação, uma qualidade diferente de intervenção dos adultos junto às crianças: "ou seja, que os adultos pudessem vir a se 
endereçar às crianças em nome de outra coisa que a moral de seu tempo batizada de 'educação para a realidade"' (2002, p. 120). Uma realidade que, em sua época, era iludida pela influência religiosa, responsável pela coerção da atividade e curiosidade intelectuais.

Toda ilusão que, se existiu ${ }^{51}$, pudesse ainda persistir em relação à função libertadora de uma educação reformada que, em última instância, promoveria sujeitos mais saudáveis e felizes, cairia por terra em 0 mal-estar na civilização, escrito em 1929. Nesse texto, Freud chega a afirmar um único caminho mais interessante de se evitar o sofrimento: os métodos (químicos) que influenciam o organismo, alterando as sensações. Não faz, propriamente, uma apologia da intoxicação, mas aponta para uma mudança radical na compreensão do papel civilizatório que a educação desempenha.

Ao encontrar na estrutura da linguagem as referências sobre o funcionamento do inconsciente (entendido como constituído de representações de palavra), Lacan mostra que a impossibilidade do gozo tem sua origem na derivação do desejo, a saber, a lei. Isto é, o gozo é barrado porque o desejo passa pela palavra e se sustenta na lei. A lei dá substância ao desejo. Nas palavras de Safouan: "Se o desejo é carne, a lei é o osso" (1996, p. 31). Portanto, o termo desejo para a psicanálise não coincide com a maneira usual, aquela em oposição à lei.

Nem uma reforma sóciopolítica, ou de costumes, tampouco de estratégia educativa, pode suplantar o mal-estar. Isto é, não é na sociedade que o sujeito encontra a felicidade, pelo contrário, civilizar-se significa abster-se de satisfação plena e imediata. Como resume Cifali (1995): a impossibilidade está no âmago do gozo humano e graças a ela a sociedade se constituiu.

Se a civilização impõe sacrifícios tão grandes, não apenas à sexualidade do homem, mas também à sua agressividade, podemos compreender melhor porque lhe é difícil ser feliz nessa civilização. Na realidade, o homem primitivo se achava em situação melhor, sem conhecer restrições de instinto (Freud, [1929] 1988, p. 119).

Não podendo furtar-se à impossibilidade de uma satisfação plena, por

\footnotetext{
${ }^{51}$ De Lajonquière afirma que Freud nunca se iludiu com a ideia de "uma educação 'no ponto' capaz de não implicar desprazer psíquico" (2002, p. 119).
} 
conseguinte, o homem encontra na restrição de seus impulsos uma fonte de realizações culturais, de progresso civilizatório, de desnaturalização, enfim, de humanização. Assim, a interdição das pulsões instintivas e o encaminhamento destas a atividades elevadas compõem o próprio sentido da educação, o qual se pode perseguir desde a revelação, pela psicanálise, de que a sexualidade não está fixada a nenhum fim e a nenhum objeto prédefinido instintivamente (como também pode prescindir de objeto, nas atividades auto-eróticas e fantasmáticas) e é, portanto, capaz de satisfazerse em atividades socialmente valorizadas.

\begin{abstract}
A sublimação do instinto constitui um aspecto particularmente evidente do desenvolvimento cultural; é ela que torna possível às atividades psíquicas superiores, científicas, artísticas ou ideológicas, o desempenho de um papel tão importante na vida civilizada. Se nos rendêssemos a uma primeira impressão, diríamos que a sublimação constitui uma vicissitude que foi imposta aos instintos de forma total pela civilização (idem, p. 103).
\end{abstract}

O papel da educação, então, é de evitar os danos que se pode perceber claramente nos casos em que a criança é confrontada na realidade com figuras parentais incapazes, a saber, quando falta ou quando excede a autoridade. A educação não deve alimentar a pulsão de agressão, mas também não deve deixar que o superego venha destruir o sujeito, através de uma repressão excessiva que, atingindo a curiosidade infantil, seja suficiente para extinguir a curiosidade intelectual ${ }^{52}$. Educar para a realidade significa, então, educar para o desejo, isto é, com vistas ao reconhecimento da impossível realidade do desejo, mascaradas pelas ilusões religiosas.

O educador deve contribuir para que o sujeito alcance seu lugar de humano "por meio do desfiladeiro da lei e de suas diferentes personificações" (Cifali; Imbert, 1999, p. 46). O que significa que pais e professores têm diante de si o problema de evitar às crianças o recalque que leva à neurose, mas também, ensiná-las a domar seus instintos e, assim, não obedecer sem restrições a todos os seus impulsos. Não pode permitirIhes total liberdade, ao mesmo tempo, equilibrar a repressão:

\footnotetext{
${ }^{52}$ Vale mais uma vez assinalar que, quando Freud menciona uma educação repressiva, se refere, em geral, aos princípios religiosos que pesam sobre procedimentos pedagógicos que, ao rejeitar a sexualidade, produzem o medo e a culpa.
} 
Assim, a educação tem de escolher seu caminho entre o Sila da nãointerferência e o Caríbdis da frustração. A menos que o problema seja inteiramente insolúvel, deve-se descobrir um ponto ótimo que possibilite à educação atingir o máximo com o mínimo de dano. Será, portanto, uma questão de decidir quanto proibir, em que hora e por que meios (Freud, [1932] 1994, p. 147).

\section{Em 1925, no Prefácio à Juventude Desorientada de Aichhorn, Freud} assinala o cerne da contribuição psicanalítica à educação:

A análise demonstrou como a criança continua a viver, quase inalterada, no doente, bem como naquele que sonha e no artista; lançou luz sobre as forças motivadoras e tendências que estampam seu selo característico sobre a natureza infantil e traçou os estádios através dos quais a criança chega à maturidade ([1925] 1988, p. 307).

Também manifesta claramente a distinção entre a educação e a análise de crianças:

... o trabalho da educação é algo sui generis: não deve ser confundido com a influência psicanalítica e não pode ser substituído por ela. A psicanálise pode ser convocada pela educação como meio auxiliar de lidar com uma criança, porém não constitui um substituto apropriado para a educação (idem, p. 308).

Freud ainda lança uma recomendação sobre o veículo através do qual os saberes educacionais e psicanalíticos estariam afinados: a formação psicanalítica dos educadores:

Não devemos presumir que esse dom de compreensão intuitiva [atribuída a Aichhorn] seja encontrado em todos aqueles que se interessaram pela educação de crianças. (...) toda pessoa desse tipo deveria receber uma formação psicanalítica, de vez que sem esta as crianças, o objeto de seus esforços, permanecerão sendo um problema inacessível para ela (ibid., $p$. 307).

A questão da contribuição psicanalítica à educação coloca em evidência a figura do professor, pois é ele quem sustenta, na prática cotidiana, a função designada ao campo educativo escolar. Portanto, da função social da Educação, passa-se a refletir sobre a natureza da relação pedagógica. 
Em Sísifo ${ }^{53}$ ou os Limites da Educação, escrito em 1925, Siegfried Bernfeld apresenta uma análise da relação do professor consigo mesmo, tendo em vista que "a natureza da relação pedagógica implica uma difícil regressão do educador à sua própria fase edípica" (Filloux, 1999, p. 15). Por sua vez, Baudouin (1964) defende que, nos casos de educadores que não experimentaram a análise (condição que ofereceria melhor domínio sobre os componentes inconscientes de sua relação com a criança), deve haver, pelo menos, alguma compreensão sobre a barreira imposta entre consciente e inconsciente. $O$ autor concebe o saber psicanalítico como auxiliar e não como substituto da pedagogia (apud Filloux, 1999).

Apesar de Freud defender, em alguns de seus textos ${ }^{54}$, a necessidade de análise dos professores e dos educadores, em especial, para analisar a presença dos efeitos transferenciais na relação pedagógica, também fala de uma formação psicanalítica.

Na discussão do texto Análise de Uma Fobia em um Menino de Cinco Anos, de 1909, pode-se ler:

... a informação obtida pela psicanálise sobre a origem dos complexos patogênicos e sobre o núcleo de qualquer afecção nervosa pode reclamar, com justiça, que merece ser encarada por educadores como um guia inestimável na sua conduta em relação às crianças (1988, p. 130).

Reafirma em 1913, no texto O Interesse Científico da Psicanálise, no subtítulo O Interesse Educacional da Psicanálise:

Quando os educadores se familiarizarem com as descobertas da psicanálise, será mais fácil se reconciliarem com certas fases do desenvolvimento infantil e, entre outras coisas, não correrão o risco de superestimar a importância dos impulsos instintivos socialmente imprestáveis ou perversos que surgem nas crianças (1995, p. 191).

Mais uma vez, na Conferência XXXIV: Explicações, Aplicações e Orientações, de 1932, vê-se a recomendação do ensino da psicanálise aos educadores:

\footnotetext{
${ }^{53}$ Sísifo, figura mitológica "cuja tarefa consistia em rolar uma enorme pedra até o alto de um morro, mas quando já se encontrava bem avançado na encosta, a pedra, impelida por uma força repentina, rolava de novo para a superfície. Sísifo a empurrava de novo morro a cima, coberto de suor, mas em vão" (Bulfinch, 2000, p. 321).
} 
Se considerarmos agora os dificeis problemas com que se defronta o educador - como ele tem de reconhecer a individualidade constitucional da criança, de inferir, a partir de pequenos indícios, o que é que está se passando na mente imatura desta, de dar a qualidade exata de amor e, ao mesmo tempo, manter um grau eficaz de autoridade -, haveremos de dizer a nós mesmos que a única preparação adequada para a profissão de educador é uma sólida formação psicanalítica (1994, p. 147-8, grifo nosso).

Em suma, os educadores devem extrair, essencialmente, duas contribuições da experiência com a teoria freudiana, sendo que a primeira abre caminho para a segunda: o conhecimento da constituição infantil e sobre si mesmos. Aliás, de acordo com Filloux (1999), a exploração analítica da relação do educador com seu projeto educativo passa a adquirir expressão maior do que a questão da figura do educador e do pedagogo diante das abordagens possíveis (orientações psicanalíticas) no trato com 0 aluno, por conseguinte, foi desencadeando uma utilização da psicanálise como leitura do que se passa no campo pedagógico.

Nesse ínterim, o conceito de transferência tornou-se o suporte genuíno para as reflexões que abrangem as relações ou disposições do educador diante do conhecimento e diante de seu ideal de aluno e, por outro lado, a posição ocupada pelo educador na subjetividade do aluno, especificamente, como sujeito suposto saber ${ }^{55}$.

Em 1914, no texto Algumas Reflexões sobre a Psicologia do Escolar, Freud concebe a relação do aluno com 0 professor estreitamente condicionada ao tipo de relação que a criança instalou na saída do período edípico. Os sentimentos de admiração, apego, hostilidade, enfim, de amor e de ódio dirigidos ao professor são transferências dos mesmos sentimentos em relação ao pai, vividos na passagem pelo complexo de Édipo. Partindo dessa perspectiva, o papel do professor em relação aos afetos que lhe são dirigidos é muito limitado, pois já estão definidos. No entanto, outros textos mostram uma dimensão importante da influência exercida pelo professor e alertam sobre os possíveis abusos do poder que lhe é concedido.

A qualidade da relação com a própria imagem, da relação com a

\footnotetext{
54 “... ninguém tem o direito de participar de uma discussão sobre psicanálise, se não teve experiência própria, que só pode ser obtida ao ser analisado" (Freud, [1933] 1994, p. 74).

${ }_{55}$ Foco da pesquisa desenvolvida como dissertação de mestrado, pela presente autora.
} 
imagem do outro, as tensões, os impasses e os momentos de "perfeição" que daí podem resultar dependem da mediação simbólica designada por "ideal-do-ego". A realidade humana é constituída de uma relação imaginária com o outro, "não há um puro sujeito simbólico, e o 'ego' se elabora a partir de identificações imaginárias" (Cifali; Imbert, 1999, p. 80).

Os desejos e fantasias do educador afetam a ação educativa. Seu narcisismo pode levá-lo a não resistir à tentação de pretender modelar a criança em função de seus próprios ideais e, assim, a criança passa a ocupar o lugar do seu desejo. Reconhecida na mesma proporção em que é destituída de si mesma, cabe à criança apenas o lugar da alienação.

No contexto escolar, o que sustenta a mobilização da função simbólica (a mediação do ideal-do-eu) transcende a figura do professor e abrange uma rede de instituições e de dispositivos de mediação. Hoje, tais instituições e dispositivos estão implicados num certo discurso pedagógico, descrito no primeiro capítulo desta tese.

Encontra-se um vasto número de personagens citados nos textos que se propõem oferecer um panorama da história das tentativas de contribuição psicanalítica ao campo educativo ${ }^{56}$. Uma história marcada por diferentes interpretações dessa contribuição, distorções, evolução, retrocesso, otimismo e pessimismo.

Como observa Lajonquière (2002), a conexão psicanálise-educação sempre esteve longe de ser um campo de grandes acordos. Isto se explica não somente pela escassez de esforço empreendido por Freud nessa aplicação,

mas, como o autor complementa: pelo fato de que todas as ilusões adultas sobre um "mundo melhor" gravitam em torno das crianças.

Apesar de permanecerem abertas as questões metodológicas

\footnotetext{
${ }^{56}$ Como em Jean-Claude Filloux: Psicanálise e pedagogia ou: sobre considerer o inconsciente no campo pedagógico (1999) e Psychanalyse e Éducation: repères (1985). E em Janine Filloux: Sur Le concept de transfert dans le champs pédagogique (1989).
} 
relativas à problemática de um "uso" da psicanálise no contexto educativo, principalmente relativas à utilização da teoria freudiana no campo da prática pedagógica $^{57}$, permanece expressiva a proposta de uma aplicação do conhecimento psicanalítico para se pensar a educação.

$\mathrm{Na}$ perspectiva psicanalítica, a educação compõe o grupo de profissões "condenadas" a resultados sempre aquém dos objetivos que se propõem alcançar: as profissões que Freud nomeou impossíveis, como governar e curar psicanaliticamente. Por outro lado e resultante dessa condição, é notório que as ilusões estão na base de toda vontade de transformação no campo educativo. Característica humana presente nas situações de perigo, privações, frustrações e impedimentos, Freud já escrevia sobre as ilusões:

Acolhemos as ilusões porque nos poupam sentimentos desagradáveis, permitindo-nos em troca gozar de satisfações. Portanto, não devemos reclamar se, repetidas vezes, essas ilusões entrarem em choque com alguma parcela da realidade e se despedaçarem contra ela (Freud, [1915], 1988).

A pergunta sobre o desejo e do impossível que o acompanha está condicionada à queda dos fundamentalismos (especialmente o religioso, dos tempos de Freud). Embora as ilusões sejam inevitáveis, assim mesmo é possível que o homem inconscientemente as saiba como tais. Dessa forma, preserva-se a distância entre o sujeito e os ideais, o lugar do desejo (Lajonquière, 2002).

É assim que, impregnadas das mesmas primeiras esperanças (ilusões) que habitaram a psicanálise interessada pela educação, no furor pela liberdade, numa apologia da natureza infantil, as últimas décadas do século XIX testemunham uma nova concepção de infância, que coloca o aluno no centro das questões escolares, sendo este pretensamente reconhecido pelo estatuto de sujeito.

Ao renovar o conhecimento sobre o infantil, destacar sua importância e sua complexidade, demonstrar a essencialidade do inconsciente na gênese das relações (a transferência na ação educativa como uma delas), explicitar as etapas do desenvolvimento infantil, a psicanálise contribuiu com

${ }^{57}$ Mais adiante, essa questão sera vista em outra perspective, a partir de Cristina Kuofer. 
a idéia da originalidade da criança, de uma visão nova da infância, da qual a educação pôde tirar proveito.

No Brasil, as recém chegadas teses freudianas compõem o plano teórico heterogêneo que fundamentou o Manifesto dos Pioneiros da Escola Nova, em 1932. Dando a palavra à criança, acentuando sua individualidade, a psicanálise adaptou-se de forma funcional aos pressupostos da nova pedagogia e serviu como proposta aos educadores responsáveis pela educação moral do povo brasileiro, rapidamente mencionada em páginas anteriores.

Absorvida pelo discurso médico desde a década de 20 (século XX), a psicanálise, então, passa a ser vista como uma solução científica para o projeto pedagógico moderno. É assim que, opondo-se à contribuição da psicologia clássica (Claparède e Binet), Porto-Carrero percebe na psicanálise uma fonte imprescindível de esclarecimento sobre os conflitos emocionais de natureza sexual que estão na origem das neuroses, portanto, segundo ele, a teoria freudiana viria "dar base científica ao que fora adquirido empiricamente pela pedagogia" (apud Oliveira, 2002, p.141).

No entanto, apesar da intensa propaganda sobre os princípios psicanalíticos, especialmente dirigida à classe dos professores; além da publicação do primeiro livro brasileiro sobre o tema $A$ Psicanálise na Educação, escrito em 1927 por Deodato de Moraes; e também, do primeiro Curso de Psicanálise Aplicada à Educação, organizado em conjunto com Porto-Carrero, ocorre um afastamento nas relações entre psicanalistas e educadores brasileiros.

Oliveira (2002) identifica dois fatores que possivelmente tenham produzido o esfriamento do interesse dos educadores pela psicanálise, entre 1928 e 1930: o primeiro seria a predominância de uma concepção de ordem psicossociológica da educação; o segundo, talvez o mais preocupante, seria uma reação a um discurso psicanalítico autônomo que, mais do que uma disciplina auxiliar, é reivindicado como um saber amplo e essencial acerca do desenvolvimento mental da criança.

Numa época de moralização dos costumes (que caracterizou 0 Estado Novo, a partir de 1937), surgem reações violentas contra a difusão de um saber e de uma visão de mundo que possibilitam um novo olhar sobre 
as normas e valores morais, apoiado no interesse pela sexualidade infantil. Nesse contexto, a psicanálise é compreendida como essencialmente pansexualista, porém, paralelamente, em outros grupos, referência obrigatória ao se falar em sexualidade.

A divisão entre os discursos (de defesa e de resistência à implantação da psicanálise no ensino, através da educação sexual dos alunos) é intensificada, na época, pela condenação do freudismo pelo Vaticano, como degradação dos valores da sociedade ocidental. É, portanto, no campo da moral que se originaram o combate mais intenso à psicanálise.

Em suma, ao desembarcar no Brasil desde a primeira década do século $\mathrm{XX}$, as disposições provocadas pelas teses freudianas oscilam entre: por um lado, um forte interesse por respeitabilidade, difusão e contribuição a outros campos do conhecimento (especialmente a educação); por outro, forte combate munido de acusações que vão desde atributos morais, como conhecimento "pernicioso", até questões acadêmicas, como de "falsa ciência do mundo subjetivo". Uma história de recuos ao campo médico-psiquiátrico e de desbravamentos de novos territórios. Inclusive, muito semelhante às outras partes do mundo.

Um aspecto positivo que resulta da luta pela implantação da psicanálise diz respeito ao alvo principal que ela logrou acertar: o fortalecimento da idéia de que é na criança que se deve agir, por constituir "o momento particular da formação da personalidade do indivíduo e sua adaptação ao meio social" (Oliveira, 2002).

Embora tenha sofrido tantas revisões, a psicanálise foi utilizada em vários textos pedagógicos como um dos fundamentos do movimento de valorização e promoção da natureza genuína da infância. Como se sabe, isto somente se explica pelo desconhecimento da estrutura paradoxal do desejo presente nos textos freudianos. Assim, recorrendo ora a Freud ora a Marx (também Nietzsche e Heidegger), um bom número de pedagogos orientou-se para o modelo de pedagogia libertária e crítica, anti-repressiva e dialética. 
infância como idade da "incompletude" e como esforço para "entrar na vida" de modo autêntico e criativo; infância que deve ser valorizada e salvaguardada por uma "pedagogia institucional" que ponha em crise a práxis pedagógico-escolar tradicional e desenvolva a "autogestão pedagógica” (...). (Cambi, 1999, p. 621)

Atingindo quase todas as áreas geográficas e culturais, nos últimos anos da década de 60 (século XX), segundo Oliveira, a "Pedagogia da Diferença" se caracterizou pelo antiautoritarismo e por depositar na figura da criança a esperança de uma nova humanidade, diferente daquela caracterizada pela tradição cristã-burguesa, considerada alienada, conformista e egocêntrica. Assim, para a "Pedagogia da Diferença", a criança representa o paradigma do modelo humano mais livre, perversopolimorfo, mais comunicativo e anticonformista, que deveria ser preservado de uma prática de vigilância castradora e, por isso, emancipada do controle dos adultos.

$\mathrm{Na}$ história das relações entre psicanálise e educação, fica evidente uma identificação com a "criança-vítima". Isto contribuiu para que, colocada no mesmo rol de muitas outras fundamentações teóricas, a leitura tendenciosa da teoria freudiana tenha alimentado a crença utópica num novo modelo formativo que visaria uma condição desalienada da vida intelectual e social, libertária, antiautoritária, erótica e criativa.

Por sua vez, a psicanálise não só adverte sobre as psicopatologias produzidas por uma pedagogia autoritária e moralizante, mas também revela o "outro lado da moeda": o autoritarismo subjacente ao discurso da formação psicológica e cognitiva ideal do aluno, muitas vezes concretizado no abandono da criança em seu próprio mundo. Nesse sentido, ao invés de situar-se "entre" Caribdis e Sila, a pedagogia é atraída pelos extremos.

A partir da psicanálise, compreende-se que o impasse da educação se define num paradoxo que Millot coloca numa definição sucinta: "a principal fonte de prazer no ser humano é de tal natureza [sexual] que este se vê forçado a defender-se dela à custa do sofrimento da neurose" (1995, p. 20). Nesse sentido, qualquer tentativa "científica" de um pretenso controle, subtraído das proposições psicanalíticas, para a produção de uma civilização mais saudável e feliz, só pode representar um erro de interpretação, motivado pela ilusão. 
Pelo primado do narcisismo é que o discurso pedagógico mantém a instituição educativa suspensa na ilusão. Seria necessário, portanto, renunciar a essa espécie de sustentação e dar lugar à realidade. Isto, porém, não significa uma adaptação ao meio ambiente, ou o sentido psicológico-adaptacionaista, como os pedagogos também costumam interpretar, mas "deixar a via aberta ao reconhecimento do desejo" (idem, p. 106) e dos conflitos entre eles.

No entanto, como discurso predominante na educação, a pedagogia está situada em oposição à psicanálise. Fixada na ilusão de domínio sobre os efeitos da relação do adulto com a criança, isto é, perseguindo uma relação de causalidade entre os meios pedagógicos utilizados e a previsão dos resultados, a pedagogia mantém-se resistente à noção de que o inconsciente do educador possui um peso maior do que suas intenções conscientes. Em síntese, para que o sonho de uma educação científica seja mantido é necessário não querer saber sobre o desejo.

A primeira edição do livro Freud Antipedagogo, de Catherine Millot, já completa vinte e seis anos e mantém-se como referência contra as ilusões pelas quais atravessaram aqueles que ansiavam uma educação reformada pela psicanálise. Sem dúvida, conservada a estrutura mesma da psicanálise, desmorona a idéia de profilaxia das neuroses por uma "educação analítica", assim como a de transposição do método analítico sobre a relação pedagógica. Porém, apesar de Millot incluir nesse "despacho" uma "pedagogia analítica" capaz de operar na resolução do complexo de Édipo e na "superação da castração", Cristina Kupfer (2001) propõe uma reanálise dessa negativa, a partir dos resultados das experiências em instituições nas quais se trabalha a Educação Especial (ou melhor, instituições clínicoeducacionais). Dentre elas: a Escola Experimental de Bonneuil-sur-Marne, na França; Le Courtil, na Bélgica; o Centro de Pesquisa em Psicanálise e Linguagem, do Recife; e o Lugar de Vida, vinculado ao Instituto de Psicologia da USP, que recebe crianças com transtornos graves de desenvolvimento: autistas e psicóticas. 
Designada por educação terapêutica, a intervenção junto às crianças do Lugar de Vida é "um conjunto de práticas interdisciplinares de tratamento, com ênfase nas práticas educacionais, que visa a retomada do desenvolvimento global da criança..." (Kupfer, 2001, p. 83). Reconhecendo como uma proposta incompleta, a autora argumenta a favor da idéia de que uma instituição atravessada pela referência psicanalítica pode produzir efeitos estruturantes nos sujeitos que assiste.

Kupfer também ressalta a influência de elementos do contexto em que Millot compõe seu livro e que justificam seu hermetismo: fundamentalmente, segundo a autora, tratou-se de um conservadorismo, ou ortodoxia lacaniana, que visava demarcar a oposição ao campo kleiniano e à "Psicologia do Ego", dos norte-americanos. Evitando os possíveis desvios que a teoria pudesse sofrer, como na fundação da Associação Internacional, - Campo Freudiano na França evitava as associações fora da filosofia, da antropologia e da literatura.

As experiências em instituições de educação especial já seriam suficientes para afirmar a presença da psicanálise na formação de educadores, já que a demanda por escolarização atinge qualquer criança, seja ela "normal" ou "desviante". Ocorre ainda que, se em toda instituição opera o discurso do mestre, por outro lado, o dispositivo educativo depende que este seja não-todo.

\footnotetext{
A saída, em resumo, só poderia ser então a de buscar uma identificação com um mestre que não é o detentor do saber absoluto, nem mestre da verdade. Será necessário buscar a identificação com um mestre-nãotodo, atravessado pela barra, pela renúncia ao Ideal, pelo saber de que seu saber é não-sabido porque funda no inconsciente e porque não sabe sobre o desejo (Kupfer, 2001, p. 78).
}

Retorna, portanto, a afirmação de que a psicanálise é o terceiro entre a educação e os ideais "fundamentalistas" ou "totalitários", fazendo emergir daí indagações. A psicanálise, como o terceiro, como o que lança luz sobre a educação e seus ideais, promove uma visão mais nítida do objeto da educação. 


\section{Psicanálise, ou o terceiro na formação de educadores}

Propõe-se, de início, um exemplo: em 2001, na Universidade Federal de São Carlos, uma professora de disciplinas ligadas à licenciatura trabalha com duas turmas: uma composta de um número reduzido de alunas (somente mulheres) do Curso de Pedagogia e, outra, numerosa, formada por alunos do Curso de Física (maioria masculina). Nessa segunda, com aulas que iniciavam às $19 \mathrm{~h} 00$ e terminavam às 23h00, a professora contava com uma expressiva disposição ao debate sobre o ensino que, muitas vezes, ultrapassou o tempo do intervalo e do término do período fixado. Situação muito diferente da que experimentava com as alunas do curso que teria o ensino como seu suposto principal interesse. As quatro aulas dedicadas à supervisão de estágio (das 14 h00 às 18h00) sofriam infinitas interrupções, para além do intervalo previsto: atrasos barulhentos, conversas paralelas e constantes saídas no transcorrer do período. O cenário se completa com uma queixa munida de aparente sustentação teóricopedagógica: "Fulana (nome da professora), sua didática é ultrapassada, pois é autoritária. Você deve prever outros intervalos para atender às alunas fumantes. Você não pode tolher nossa liberdade de fumar..."

O exemplo parece ser suficiente para iniciar um debate sobre o lugar do conhecimento, ou melhor, sobre as características das relações que sujeitos atravessados por diferentes discursos estabelecem com o saber. $O$ que interessa particularmente a este trabalho é assinalar as amarras existentes entre o modelo de formação de professores e o discurso que supostamente lhe prepara para o ofício de ensinar.

No papel de aluno, os professores mostram-se francamente inclinados a identificar-se com os ataques à autoridade de seu formador, uma vez que é constantemente combatida pelo discurso que lhes engolfam, isto é, o da "Pedagogia Científica". Por outro lado, nas escolas onde trabalham, se deparam com o "constrangimento" de ocuparem o mesmo lugar.

Atravessada pelo saber psicanalítico, em $A$ Arte de Formar: 0 Feminino, o Infantil e o Epistemológico, Márcia Neder Bacha (2002) analisa 
o professor que ocupa o lugar de aluno na universidade. A autora pensa esse contexto (dividido) em termos de uma rivalidade com o pai. No exercício de professor, segundo Bacha, a identificação com a autoridade atacada desencadeia a angústia e, por conseguinte, aflora uma outra dimensão da formação: as temidas normas que emanam da figura representante da lei (a autoridade paterna), mesmo que também desejadas, são desafiadas na demanda pelas "receitas" ao campo psi, que como monopólio, impõem-se como normas. Em outras palavras as "receitas" funcionam como antídoto contra a "autoridade" e, no entanto, produzem outro tipo de autoritarismo, que pode ser percebido na fala que a aluna dirige à professora no exemplo.

Como observa Lajonquière (1999), a demanda (por receitas) endereçada à psicologia, ou psicologização do ensino, é resultado da forma de como o discurso pedagógico entende a educação, a saber, como estímulo das capacidades cognitivo-emocionais. Assim, através da aplicação de métodos, pretende-se "obter um saber sobre a singularidade de um episódio subjetivo" (1999, p. 59). Diante desse equívoco, a psicanálise faz conhecer a impossibilidade estrutural que constitui a demanda pedagógica e alerta para o fato de que, na medida em que se insiste nessa direção, as coordenadas que devem inspirar o cotidiano escolar são apagadas.

Quais dificuldades se podem impor a uma formação que "navega contra a correnteza"? Uma vez atravessado pela psicanálise, o formador de professores (como no exemplo real apresentado), está sujeito a duplo ataque: à autoridade sustentada pelo semblante de saber e pela ausência de oferta de modelos. De fato, a contribuição maior da psicanálise à educação reside em assinalar as condições que podem vir a torná-la de difícil acontecimento, ao passo em que revela seu dispositivo.

Em "resposta" aos ataques, a psicanálise resgata o sentido da educação que não é outra coisa senão o de confrontação à ordem simbólica, ordenando as relações na sociedade. Portanto: "Sustentar e transmitir às novas gerações a tradição simbólica que funda, de uma só vez, o sujeito e a cultura, tal é a tarefa imposta pela civilização ao adulto na posição de educador, não importa se pais ou mestres" (Almeida, 1999, p. 67). A disposição para assumir tal tarefa, portanto, para ensinar, tem origem na 
dívida que o próprio adulto contraiu pelo benefício de ser introduzido (pelo outro) na linguagem e no pensamento (ao Outro).

Nesse conjunto, a constatação da função mediadora da palavra implica também em reconhecer que ela carrega duas características aparentemente contrastantes. A primeira delas diz respeito à sua função fundadora, isto é, formadora de um todo, como assinala Safouan:

\footnotetext{
Nenhuma sociedade e nenhuma transmissão são possíveis onde as palavras não têm, em princípio, uma força amalgamante e onde ninguém lhes dá crédito. A sociedade e a transmissão são possíveis porque as palavras têm um valor tal que dizer alguma coisa é dizer uma coisa que se crê verdadeira ou que se quer que o ouvinte creia verdadeira (1996, p. 30).
}

A segunda se relaciona com a "verdade" da palavra e permite compreender a natureza da impossibilidade estrutural que a psicanálise descortina. Ela se relaciona com um elemento fundamental da cognição: a fala mediada pelo outro. De outra maneira, poderia se dizer que o problema da educação passa pela palavra e pelo fato de que o sujeito (falante ou ouvinte) está, por princípio, implicado em todo ato. Dessa forma, aquilo que se diz ou o que se escuta não se ajusta a nenhuma medida, é um pouco mais ou um pouco menos, sempre diferente da intenção do ato, submetido que está ao desejo do sujeito (este assujeitado ao desejo). Portanto, em última instância, é o desejo que fala.

Por isso, a psicanálise designa por desejo de saber o enfeixamento de uma série de condições particulares e significantes que formam o dispositivo do ato educativo (Lajonquière, 1999). A aceitação disso por parte daqueles impregnados do discurso pedagógico, bem como de um grupo maior de racionalistas-cientificistas, repousa no fato de que o desejo sempre se revela après coup, então, reclama a renúncia à idéia clássica de controle e previsão.

Assim, sustentar a transmissão significa suportar, subjetivamente, a angústia de uma posição discursiva que exige a renúncia da onipotência narcísica e dos ideais de grandeza e de perfeição. Por isso, como se pôde refletir sobre a questão do estilo no terceiro capítulo, a partir da compreensão psicanalítica, para que o ensino e a transmissão sejam 
possíveis e realizáveis, o lugar que o educador ocupa é o de semblante de saber, isto é, o lugar de Mestre, não o do dogma, mas como não todo.

A contribuição psicanalítica à educação reside em declarar a necessidade de uma postura reflexiva sobre a tarefa educativa que, no entanto, não se confunde com a proposta reflexiva da "Pedagogia Científica”. Apoiando-se no pensamento de Ardoino, Imbert (2001) enfatiza a exigência do reconhecimento de que a reflexão e a racionalidade devem ser partes integrantes do questionamento que incide sobre as práticas, porém, isso não implica que se esteja adotando um procedimento científico. Se a racionalidade é a "inteligência da ordem" e procura sua demonstração na natureza "dedutiva e preditiva de seus enunciados", a reflexão é a "inteligência da desordem", integra o desejo, a efervescência afetiva e os conflitos que o acompanham.

\footnotetext{
Esses deslizes entre referenciais heterogêneos - entre ideal de cientificidade e simples rigor de uma tentativa "racional", entre abordagem científica experimental e procedimento clínico -, dão testemunho, inclusive através da confusão epistemológica, do que o autor não consegue confessar senão indiretamente e sem reconhecê-lo, a saber: a prática pedagógica pode, sem dúvida, apoiar-se em dados, conclusões $e$ enunciados científicos; no entanto, a propósito dessa prática, faltam-lhe argumentos para falar de cientificidade (Imbert, 2001, p. 51).
}

A reflexão proposta pela psicanálise supõe que o professor faça uma re-significação de sua atuação junto aos alunos. Isto implica em redimensionar as metas idealizadas que tentam inspirar o ato educativo na atualidade e que, diferente da "retrógrada" intenção de atingir um ideal humano, agora, visa uma adequação científica animada por teorias psicológicas e aportes tecnológicos.

A atual disposição do campo pedagógico nega a realidade do desejo e, por conseguinte, professor e aluno como sujeitos. $O$ conceito de transferência demonstra que a posição subjetiva do professor determina as suas modalidades discursivas, produzindo diferentes repercussões na transmissão e na aquisição do conhecimento. Por isso, segundo a psicanálise, não se trata de ajustar ou adequar a intervenção do adulto a uma realidade infantil prévia, mas do questionamento sobre aquilo que a criança lhe representa inconscientemente e que está presente em seu 
discurso.

Portanto, deparar-se com a psicanálise em sua formação implica na passagem do educador pela compreensão sobre sua própria infância que, diferente de um método, consiste em uma reconciliação com o passado, então, consigo mesmo, pela via do questionamento.

$O$ “interesse pedagógico" (Freud) da psicanálise reside na indagação que promove. Semelhante afirmação é válida tanto no contexto de uma análise pessoal empreendida por um adulto - educador circunstancial ou profissional - quanto naquele da elucidação do discurso (psico)pedagógico hegemônico (Lajonquière, 1999, p. 62).

A reflexão que a psicanálise promove volta-se para a inconsistência do discurso pedagógico atual, pretensamente científico, na medida em que indaga sobre aquilo que a criança lhe representa. Conseqüentemente, oferece condições para que "os adultos venham a assumir a responsabilidade pelo mundo velho onde introduzem de fato as crianças" (idem, p. 62).

Por outro lado, apesar da simplicidade do dispositivo educativo, como exposto por Lajonquière (1999), reconhece-se a dificuldade para se assumir semelhante responsabilidade no campo familiar e na educação escolar. Isto é, não é sem conflitos que alguém abriga a posição de educador. Isto porque, a formação do outro, como considera Bacha, possui algo inquietante: mobiliza angústias, desejos e, conseqüentemente, defesas. Como formadora de professores, a autora relata uma inversão na demanda no final de um período letivo:

Todos haviam partido de uma convicção e de um intenso desejo: um método para ensinar, uma receita mágica para motivar, uma poção para acordar e se acordar, enfim, um feitiço para conquistar e seduzir a atenção e o interesse do aluno e, evidentemente, o seu. No meio do caminho foram surpreendidos por um desvio: o professor. Descobriram a si próprios na educação e isso não é pouca coisa. Não é para essa figura que a psicanálise aponta ao situar na transferência todo o eixo da educação? (2002, p. 53).

A partir da torção que o discurso psicanalítico vem provocar nas referências à formação dos educadores, a ênfase na adequação, no método, passaria a dar lugar ao reconhecimento do conflito inerente ao ofício de 
educar, ao questionamento sempre presente sobre o desejo que se alinha a essa responsabilidade. Por exemplo, uma vez alojados no inconsciente, o ódio ao infantil ou o temor de ser nocivo à criança podem estar disfarçados na demanda por ferramentas psi e científicas que "justificam" a retirada do adulto da cena educativa, produzindo, dentre outras construções racionais, a idéia de "criança autônoma".

Portanto, ao invés de buscar fundamentação ou autorização num discurso que the é externo, meramente auxiliar e que, em última instância, impede-lhe a visão de si, o professor pode mergulhar na complexidade dos fantasmas inconscientes que a situação formativa lhe desperta, aproximarse dos fundamentos e disposições que caracterizam a sua singularidade como educador, seu estilo.

Vale assinalar que não se está afirmando a necessidade de que o professor saiba psicanálise para ensinar bem, o que significaria sustentar que, fora da transmissão psicanalítica, não tenham existido bons educadores ao longo da história da Educação. Em O Avesso do Modelo: Bons Professores à Luz da Psicanálise, Marcelo Ricardo Pereira é bastante esclarecedor a esse respeito:

\footnotetext{
Bons professores, como assim se posicionaram nossas entrevistas, inventam modelos de prática que se desvanecem tão logo são postos em ato. São modelos que escapam à normatização, pois tais professores não parecem querer tudo condicionar à lei. A bem da verdade, procuram soluções metodológicas, mas intuem a existência de algo que excede a objetividade e dela é excluído. Chegam a inventar modos de fazer que suportam a dessimetria presente, por exemplo, na relação entre educadores e educandos. Talvez estejam mais aptos a admitir modalidades estranhas ao discurso pedagógico, como o sujeito do inconsciente... (1998, p. 125).
}

Pode-se relacionar a "invenção de modos de fazer" e a "intuição", sobre os quais Pereira se refere, ao que aqui tem sido designado por estilo. Qual seria o denominador comum entre os bons professores da pesquisa do autor (que ignoravam a psicanálise) e os efeitos que a transmissão psicanalítica dispara na formação de educadores? O desvio da cilada de se pensar como mestre-todo-saber, permitindo, dessa forma, que o ideal não apague o sujeito.

Também se pode deduzir do texto de Pereira aquilo que o conceito de 
transferência ilumina sobre a ação educativa, a saber, a relação que os sujeitos estabelecem com o conhecimento, assim como seu produto, as razões e as fantasias com as quais a atividade do educador é revestida. Não se pode negar que o desejo do professor pelo seu conhecimento, a relação apaixonada com o conhecimento que veicula, é a principal fonte inspiradora do aluno que aprende.

Mais uma vez no intuito de demonstrar o "avesso do modelo", em texto recente ainda não publicado, Pereira analisa a figura do professor George Lopez do documentário "Ser e Ter" (de Nicolas Philibert, 2002) que conduz seus alunos e alunas "algumas vezes com rigor, outras com simpatia, outras vezes mais com certa moral irredutível, própria da profissão, mas nunca com muitos excessos." Sem mimos ou superproteção, afirma Pereira, Lopez estimula seus alunos a vencer medos e encontrar suas próprias marcas. Baseando-se no amor e no rigor, produz uma confiança desarmada e o desejo de ser reconhecido por ele (o mestre). Ao mesmo tempo em que encarna o mestre que seu desejo o impulsionou a ser (sem falhas), em seu ensino se posiciona de modos diferentes a cada instante. Sua finitude, uma marca que já tolera, impede que permaneça idêntico a si mesmo.

Ser e Ter remete-nos ao jogo dialético do desejo que, invariavelmente, induz qualquer professor ao impossível. De um lado, enquanto sujeito, há o desejo que o impele a ocupar o lugar de mestre; do outro, precisa renunciar a esse desejo para tornar-se um depositário esvaziado dos sentidos imprimidos por um aluno (2005, p. 19).

Em outras palavras, se se pensar como mestre-não-todo é uma condição para o ensino, o discurso atual predominante na educação, na contramão desse dispositivo, é que vem tornando a psicanálise uma referência cada vez mais imprescindível à educação. Não no sentido de ensinar a ensinar, tampouco de aprender a aprender. Enfim, o que se pretende afirmar é a condição que a psicanálise oferece para que se pense os problemas recorrentes no contexto atual da educação, que têm origem na perda do seu eixo: a violência, o desinteresse e o baixo nível da formação dos alunos. 


\section{O eu do sujeito versus o sujeito do inconsciente ou, a especificidade freudiana}

Os dois primeiros capítulos desta pesquisa ressaltam a diferença estrutural entre a pedagogia (especialmente a de hoje) e a psicanálise. Contudo, para alguns, essa distinção permanece pouco clara, tendo em vista a sobreposição de propostas pedagógicas para integração do atributo cognitivo com o que designa por "o emocional", que se supõe objeto da psicanálise. Há uma tendência na pedagogia em compreender os transtornos na aprendizagem como produtos ora da disfunção cognitiva, para os quais os instrumentos construtivistas (ou pretensos) estariam a serviço, ora de um "emocional abalado". Este segundo podendo interferir no funcionamento do primeiro.

A psicanálise, do sujeito dividido, não habita o terreno das ilusões sobre uma inteligência emocional integradora e, como especifica Kupfer, ela: "não trata das emoções e, tampouco, do desenvolvimento afetivo" (2001, p. 19). Nessa frase, é recuperada a afirmação freudiana de que não são os afetos ou as emoções que sofrem o recalque, mas as representações. Essas, então, inconscientes, estariam na origem das manifestações dos sintomas que, por sua vez, levam o sujeito ao sofrimento.

Não provém da psicanálise, segundo Kupfer, mas de diversas correntes psicológicas que se origina a idéia (que a pedagogia toma para si) de que as crianças padecem de problemas emocionais: "Uma psicologia que sofreu a influência da psiquiatria e absorveu alguns princípios da psicanálise, mas não deixou de lado a ciência do comportamento" (idem, p. 21). Sobretudo, pode-se acrescentar que aquilo que a psicanálise faz ver como estrutura da educação se dissipa com uma compreensão do ato educativo, proveniente da psicologização da educação.

Sede das funções que regulam a relação de uma pessoa com a realidade, o eu ocupa o lugar central nas psicologias, mesmo naquelas não estritamente comportamentais. Disso surgem as definições em torno de um tipo psicológico que represente uma relação adequada com o campo social, conseqüentemente, a proliferação da idéia de adequação no âmbito da 
"Pedagogia Científica".

No entanto, a psicanálise se dirige ao sujeito que não se confunde com o eu. Não é (do) organismo, não é da racionalidade, nem da lógica, nem da consciência, nem regido pelo princípio da realidade. O sujeito da proposição psicanalítica é constituído pela linguagem, não como comunicação, mas como um encadeamento de representações que formam uma trama sempre singular em cada sujeito. Em outras palavras, sua estrutura psíquica constitui-se num conjunto de significações que representam o lugar que ele ocupa no desejo do Outro.

$\mathrm{Na}$ formação de educadores, a psicanálise apresentaria, portanto, uma especificidade: para além da resignificação dos ideais, seu ensino marca a possibilidade de uma educação que leve em conta o sujeito do inconsciente. Em primeiro lugar, isto representa outra dimensão atribuída às técnicas de adequação social, aos métodos de ensino, à tecnologia, à previsão e ao controle científicos, que passariam a ser apresentados como coisas do mundo, como tantas outras paralelas à educação, no limite, auxiliares, mas não tomados por seu eixo.

Sem dúvida que os objetos produzidos pela cultura devem ser contemplados pelo aluno e instigá-lo na construção de outros objetos, mas não devem ser pensados como permanentes, mas como auxiliares na busca por respostas e nas infinitas configurações da manifestação do desejo de saber, além de que, o aluno se servirá dos objetos do mundo à medida que Ihe dizem respeito,

\footnotetext{
nos quais está implicado por seu parentesco com aquelas primeiras inscrições que lhe deram forma e lugar no mundo. Com essas palavras e objetos da cultura, poderá dizer-se escrevendo, por exemplo, uma poesia, na tentativa de capturar ou dar forma aos paradoxos que o movem (ibid., p. 125).
}

Abrangendo outras dimensões da especificidade do ensino da psicanálise a educadores, pode-se afirmar que: levando em conta o sujeito, - educador saberá que, apesar das marcas e da determinação das inscrições primordiais, a aprendizagem do aluno não está predeterminada em limites, direção, tempo ou meios. Logo, tomará para si a responsabilidade por seus atos educativos e, possivelmente, fará diminuir o 
número de encaminhamentos a especialistas, como os do campo psi.

Isso reafirma a noção de que a contribuição psicanalítica aos educadores não tem caráter técnico, mas uma referência na compreensão de sua relação com o ofício de educar (redimensionamento dos ideais que se the apresentam, como já foi abordado), sua transmissão "capacita" o reconhecimento do sujeito no lugar da valorização do objeto, consequentemente, gerando mudanças na posição do educador frente ao aluno. Enfim, o reconhecimento do ato educativo.

Em síntese, a transmissão da psicanálise a educadores produz efeitos. Em contato com a psicanálise, o educador ouve falar sobre o sujeito e passa a levá-lo em conta. Sem fixar-se em métodos e sem saber antecipadamente como atingir o aluno, "reaprende que visa à consciência mais atinge o sujeito" (ibid., p. 122). Atravessado pela psicanálise, o professor reconhece a necessidade de se debruçar sobre a forma peculiar de aprender de cada criança.

Por isso, é possível pensar na noção de estilo. Sujeitos singulares, de histórias únicas; constituídos por singulares tramas de representações; com um modo próprio de negar a falta; cada professor, assim como cada aluno apresenta seu estilo.

Ao mesmo tempo em que é único em cada sujeito, em que traduz sua maneira peculiar de relação com o conhecimento, portanto, não pode ser copiado, paradoxalmente, o estilo é aquilo que se transmite. Isto porque, o estilo se constrói nos sucessivos encontros com os objetos do conhecimento, que moldam os próprios objetos e estabelecem os padrões de relação com aqueles que estão imbuídos da tarefa de transmiti-los.

Ao contemplar o outro no exercício de seu estilo próprio, uma criança construirá e se construirá em seu estilo. Ao contemplar o professor no exercício de seu estilo de apropriação do objeto de conhecimento um aluno construirá e se construirá em um estilo cognitivo próprio (ibid., p. 129).

O modo próprio de o sujeito-aluno escrever, de falar, de aprender, configura, então, seu estilo cognitivo. Portanto, também o sucesso e o insucesso (assim como a produção mediana) são manifestações da conexão entre o estilo cognitivo do aluno e o discurso social escolar dominante. E, 
detalhando ainda mais a ideia da transmissão do estilo do professor no âmbito do ensino das disciplinas escolares, Kupfer explica:

\begin{abstract}
O estilo do educador será o seu modo de obturar a falta no Outro. Foi com a geografia ele diz; ou melhor, ele diz: testemunhem o modo como me relaciono com o objeto de conhecimento e terão uma apreensão de como ele participa de minha economia libidinal, como eu o faço desdobrar-se em cadeias infindáveis, como ele me distrai de minha falta. O que transmite então é esse como, esse modo de relação, que é vazia, mas ele transmite "recheada" digamos assim, com os conteúdos da matéria que ele estiver ensinando. Seu aluno tomará dessa estrutura vazia para novamente "preenchê-la". Dali surgirá um novo estilo marcado, porém por aquele de seu professor (ibid., p. 134-5).
\end{abstract}

Uma condição para que a construção freudiana alcance o educador parece ser, portanto, a de evidenciar a diferença entre: a pedagogia, um conjunto de saberes positivos; e a educação, os efeitos subjetivantes da relação da criança com o adulto. Logo, a crença na existência de uma adequação (natural) entre a intervenção educativa e a realidade psicológica do aluno reside na forclusão do que a psicanálise considera a essência da educação.

Como não há ressonância entre os discursos (pedagógico e psicanalítico), cabe, não apenas afirmar a impossibilidade de uma "Pedagogia Psicanalítica", mas exercer a tarefa de consumir as ilusões pedagógicas no interior do campo educativo. Por outro lado, apoiando-se num extenso conjunto de trabalhos que se debruçam sobre a conexão psicanálise- educação, a presente pesquisa vem reforçar a factibilidade de uma educação orientada pela psicanálise, uma educação para a realidade impossível do desejo.

Tal proposta apóia-se essencialmente na perspectiva psicanalítica sobre o papel fundamental da educação na constituição do sujeito. É por meio da educação que o Outro é incorporado ao substrato orgânico, transformando o que era somente biologia em linguagem. Isto porque, assim como o humano, o significante criança também supõe uma construção da linguagem sobre o substrato biológico. Em outras palavras, o adulto marca de desejo seu filhote fazendo-o tornar-se uma criança, já que, agora, ocupa seu (um) lugar na linguagem. Capaz de produzir discurso, a criança dirige-se ao outro, consequentemente, estabelece laço social. 
Em suma, para a psicanálise, cada vez que um adulto se volta para uma criança a fim de filiá-la a uma tradição, de fazê-la reconhecer-se no outro, está produzindo um ato educativo. Sendo assim, ao constatar que a educação é um discurso social a psicanálise "se põe a dialogar com ela nas escolas, na mídia, na universidade" (ibid., p. 118).

Considerando, no entanto, que a aquisição de todo a qualquer conhecimento dá-se a partir da implicação do sujeito, o saber psicanalítico somente poderá ser produtivo se o educador puder se apropriar desse saber, ou melhor, na condição do questionamento e reposicionamento das ilusões que este mantém em torno da função educativa: "De fato, a psicanálise tem muito a dizer sobre a escola, a propósito da relação com o saber, sobre a pessoa, sobre o grupo, sobre a instituição, o que não chega a ser uma novidade, já que enunciada por Freud desde 1913" (Lopes, op.cit., p. 115).

Algumas passagens anteriores permitiram compreender que no cerne das revoluções e modismos de práticas pedagógicas, no interior da educação, encontra-se (como ainda hoje) um ideal de homem. Logo, o discurso pedagógico deixa claro o imperativo dirigido a professores e alunos no sentido da conformação aos ideais que estabelece. Daí, como afirma Voltolini (2001), reside a resistência ao discurso analítico que, por sua vez, não oferece espaço de convivência pacífica com a sustentação de ideal de homem. Finalizando, em oposição à paralisia (neurótica) produzida pelo ideal de homem, a psicanálise promove uma mudança subjetiva, implicando o sujeito, fazendo-o reconhecer-se pelo questionamento do ideal. 


\section{CONSIDERAÇÕES FINAIS}

\footnotetext{
“... gostaria que vocês escutassem a seguinte - é que na medida em que logre, em que consiga fazê-los entender alguma coisa, podem estar certos de que os terei sacaneado" (Lacan, 1970).
}

Dar um sentido, traduzir a intenção, assim como procurar iluminar 0 percurso traçado nesta pesquisa consiste, por um lado, num empreendimento acadêmico-metodológico necessário, por outro lado, uma tentativa que exemplifica boa parte daquilo que se chamou especificidade da contribuição psicanalítica aos educadores. Para começar, como propósito de tradução da verdade, a transmissão está distante de representar o "ensinar bem", o ideal de resultado positivo em torno do qual se estrutura o discurso universitário. Compreender essa proposição implica, pela via da psicanálise, recolocar e redimensionar as noções de verdade e de saber, consequentemente, de apreensão do real, de realidades singulares, de sujeito.

Em A impotência da verdade, texto publicado no O Seminário - livro 17: $O$ avesso da psicanálise (1970), Lacan detalha seu título da seguinte maneira: a verdade, que nos liga e separa do real, tem a impotência como sua irmãzinha e protetora. Isto significa dizer que, para que a verdade seja articulada, a aproximação dela está condicionada ao reconhecimento de sua impossibilidade. Em outras palavras: deve-se reconhecer a verdade como impossível para que se possa falar "verdadeiramente de verdade". Assim, "o amor à verdade", expressão recorrente no discurso psicanalítico, remete a 
tal aproximação que, em última instância, seria o reconhecimento da verdade como composta de infinitas faces.

Da mesma forma, se a verdade é o que liga cada sujeito ao real, também se deve reconhecer que a apreensão do real, por ser impossível uma relação com ele, passa pelo reconhecimento de que fabricamos realidades. Isso também implica em dizer que, se o real se define como impossível é por que não há um verdadeiro registro simbólico em que se possa situar o real.

Então, anunciada a impossibilidade em seu "devido lugar", a saber, no conhecimento positivo da verdade e do real, torna-se elucidada a natureza impossível das três profissões citadas por Freud. Se o real não é para ser sabido, como diz Lacan, é, no entanto, o único dique para conter o idealismo. Os ideais, ao mesmo tempo em que armazenam o mal-estar que a impotência causa ao sujeito na sua relação com a verdade, no limite, também produzem "cegueiras".

No contexto da formação universitária destacam-se, basicamente, dois ideais: o primeiro, definido por "discurso universitário", pretende produzir um ser pensante, através de mecanismos regulados institucionalmente e que supostamente garantam um ensino sem "furos"; o segundo privilegia a veiculação do discurso da ciência, que precisa "possuir" o objeto a para ser desejado. Como já foi exposto ao longo do presente texto: enquanto o discurso da ciência pretende representar o saber sobre a verdade, o discurso universitário propõe a garantia na transmissão dessa mesma verdade. Em suma, um conhecimento "científico", legitimamente garantido pelas instituições acadêmicas.

Um extenso debate se propaga no campo da Filosofia da Ciência e da Epistemologia. Concepções mais radicais, como a de Popper, são refutadas por análises mais flexíveis, como a de Pierce, de Kuhn e de Laudan. A partir de diferentes cadeias de argumentos, ora comungando ideias, ora opondose veementemente entre si, são apresentadas diferentes perspectivas sobre - mérito dos variados campos de investigação e de produção de conhecimento. Nesse contexto, encontra-se o polêmico debate sobre 0 status epistemológico da psicanálise.

Enquanto filósofos e epistemólogos examinam a condição da teoria 
psicanalítica no campo do conhecimento, esta, como em espelho, elucida elementos estruturais da disposição diante do saber, portanto, aquela mesma dos cientistas, assim como, dos seus examinadores. Safouan contempla os meandros do não racional na produção científica, no seguinte trecho:

\begin{abstract}
Toda ciência conserva a marca de sua origem, da influência pessoal dos mestres pelos quais ela foi criada e desenvolvida, da obediência cega ou da revolta das gerações recentes perante seus predecessores. Em suma, o espírito humano aí está presente, na forma de um conjunto inteiro e indivisivel, com cada um de seus componentes e cada uma de suas tendências. O desenvolvimento de uma ciência é, sem dúvida, menos influenciado pelas emoções e fantasmas do que o dos conceitos políticos, sociais ou religiosos, mas seria um grande erro considerar sua veracidade e sua precisão no que diz respeito aos detalhes, como prova absoluta de um progresso sereno e sem interferência em direção ao objetivo da verdade última. Personalidades e animosidades, pequenas e grandes, são aí conservadas como fósseis, e preservadas em locais onde o espírito erudito não as reconhece, sob seu disfarce de lógica estrita e de aspecto gentilmente racional (1996, p. 102-3).
\end{abstract}

Segue afirmando o papel da ilusão (contida nos ideais) para profusão da confiança cega na racionalidade da produção científica, atingindo quase a totalidade da produção acadêmica, assim como boa parte da cultura mundial.

\begin{abstract}
A hipótese segundo a qual os erros são de curta duração e a verdade eterna talvez seja tranqüilizadora em retrospectiva, ou a uma grande distância, mas não ajuda a resolver as dificuldades de uma situação determinada. Os erros, mesmo se são de curta duração, podem se estender sobre um bom número de gerações e mostrar uma grande capacidade para se desenvolver e se ampliar. Cada fase de toda ciência reconhecida, quer seja um progresso esplêndido ou um declínio lamentável, tornar-se-á, de modo completamente perceptível, um fenômeno de psicologia das massas (idem, p. 103).
\end{abstract}

Corroborando com a ideia de que a psicanálise pode contribuir com a epistemologia, como "psicanálise do conhecimento", Bachelard (1996) a define como ferramenta reveladora do inconsciente na produção científica, cuja intervenção no campo racional se reveste de resistência à objetividade, designada por "obstáculo epistemológico" que, paradoxalmente, é condição do desenvolvimento do conhecimento científico.

A fim de que as descobertas científicas (assim como o crivo epistemológico imposto a elas) não se configurem em confiança "surda e 
cega" na racionalidade do empreendimento do cientista, filósofo ou epistemólogo, um elemento, um elemento deve se impor à relação entre criador e criatura, um outro que sustente o lugar de terceiro, a saber, aquele que interroga. A presente pesquisa procurou demonstrar que a psicanálise é o terceiro que interroga os alicerces da formação do educador na atualidade. Se não atende aos ditames da ciência tradicional, por isso mesmo deve ser "ensinada" aos futuros educadores, posto que a educação está para além da ciência e do discurso universitário.

... o modelo de conhecimento proposto por esta universidade engendra um tipo de laço social e de relação inter e intrasubjetiva entre o Saber e o sujeito que promove e faz apelo às relações imaginárias na educação $e$ aos ideais megalomaníacos e narcisistas do educador (Almeida, 1999, p. 67).

O estudo da psicanálise permite ver a proliferação de dogmas no contexto estabelecido da universidade, assim como as ilusões que compõem o discurso pedagógico. Este, sob a designação de "Pedagogia Científica", tem arbitrado a legitimidade das ciências da educação, o conjunto de saberes que, ou corroboram com os ideais cientificistas, ou são interpretados de forma a se adaptarem a eles, como é o caso da leitura realizada a partir do construtivismo.

Muito longe dos ideais cientificistas da pedagogia e da transmissão sem efeitos da ilusão universitária, o ensino da psicanálise a educadores abre-lhes as possibilidades para pensar suas relações com o saber e com o exercício de educar. Mais do que um manejo teórico, os efeitos da transmissão da psicanálise produzem mudanças de posições, uma outra forma de enxergar a si e ao outro. Por isso, no lugar de buscar garantias racionais e metodológicas, o educador atravessado pela psicanálise conhece e assume a responsabilidade pela transmissão, pois reconhece que não há transmissão/educação sem implicações.

Nesse contexto, a presente pesquisa contribui com a proposta de que a psicanálise atue na formação de educadores, como o que Lopes designa por uma disciplina antiideal, que permita constatar as idealizações paralisantes. Reconhecendo que a psicanálise não é tudo, a autora complementa: "A psicanálise não tomará o poder, não dará o poder a quem 
quer que seja (...)" (2003, p. 122). Em última instância, o encontro dos educadores com a teoria psicanalítica, na "contramão" dos rumos que tem tomado o cenário pedagógico, recolocaria a educação no eixo da interrogação ética, opondo-a aos fascínios imaginários (assim como às intenções de moralização e segregação), despotencializando as identificações que sustentam os delírios de ideal e as sujeições identitárias. Projeto descrito por Imbert no último parágrafo de um de seus textos e que também sintetiza as idéias finais deste.

A afirmação da liberdade e da singularidade do sujeito constitui a única referência - de algum modo, a uma lei -, que possa subtender o projeto de uma práxis educativa; ou seja, conduzir o pedagogo e o educador a reconhecerem sua "vontade cega" (D. Vasse) de "fabricar" e enfileirar, de possuir e manipular, além de se interdizerem de se deixar arrastar pelo arrebatamento da pulsão $(2001$, p. 142). 


\section{BIBLIOGRAFIA}

ALBERTI, S.; ELIA, L. (orgs) Clínica e pesquisa em Psicanálise. Rio de Janeiro: Rios Ambiciosos, 2000.

ALMEIDA, S. F. C. de. Psicanálise e educação: entre a transmissão e o ensino, algumas questões e impasses. Anais do I Colóquio do Laboratório de Estudos e Pesquisas Psicanalíticas e Educacionais sobre a Infância FEUSP, 1999, PP. 63-69.

ALTET, M.; PAQUAY, L.; PERRENOUD, P. (et alii) A profissionalização dos formadores de professores. Porto Alegre: Artmed, 2003.

AULAGNIER, P. Um intérprete em busca de sentido. São Paulo: Escuta, 1986.

AVANZINI, G. (org.) A pedagogia atual: disciplinas e práticas. São Paulo: Edições Loyola, 1999.

BACHA, M. N. A arte de formar: o feminino, o infantil e o epistemológico. Petrópolis, R.J.: Vozes, 2002.

BACHELARD, G. A formação do espírito científico: contribuição para uma psicanálise do conhecimento. Rio de Janeiro: Contraponto, 1996.

BARROS, R. R. O Psicanalista em sua formação. Psychê: Revista de Psicanálise. São Paulo: Unimarco Editora, ano 3, n. 3, 1999, pp. 29-35.

BIRMAN, J. Psicanálise, ciência e cultura. Rio de Janeiro: Jorge Zahar Ed., 1994.

BULFINCH, T. O livro de ouro da mitologia: história de deuses e heróis. Rio de Janeiro: Ediouro, 2000.

CAMBI, F. História da Pedagogia. São Paulo: Fundação Editora da UNESP, 1999.

CARVALHO, J. S. F. de. Construtivismo: uma pedagogia esquecida da escola. São Paulo: Artmed, 2001.

CAVALCANTE, A. E.; CARDOSO, C.; ROCHA, P .S. Reflexões sobre a instituição psicanalítica na contemporaneidade. In: Função Paterna, Maria Rita Kehl (org.). Rio de Janeiro: Relume Dumará, 2000, pp. 111-142.

CHAUI, M. Espinosa: uma filosofia da liberdade. São Paulo: Moderna, 1995. 
CIFALI, M.; IMBERT, F. Freud e a Pedagogia. São Paulo: Edições Loyola, 1999.

CIFALI, M. Educar, uma missão impossível - dilemas atuais. Estilos da Clínica: Revista sobre a infância com problemas. São Paulo, Pré-Escola Terapêutica Lugar de Vida, IPUSP, n. 7, 1999, pp. 139-150.

L'Infini Éducatif: Mise em Perspective. Paris: Presses Universitaires de France, 1986.

DOR, J. A-cientificidade da Psicanálise: tomo I, a alienação da Psicanálise. Porto Alegre: Artes Médicas, 1993.

DUARTE, N. As pedagogias do "aprender a aprender" e algumas ilusões da assim chamada sociedade do conhecimento. Revista Brasileira de Educação, Associação Nacional de Pós-Graduação e Pesquisa em Educação, n. 18, 2001, pp. 35-40.

ENRIQUEZ, M. (1979) Forma-se um analista. Percurso: Revista de Psicanálise, n. 12, 1994, pp. 12-20.

FERRACINI, G. Biografias. São Paulo: Scipione, 1996, 3v.

FERREIRA, T. Freud e o ato do ensino. In: A Psicanálise Escuta a Educação; Eliane M. Teixeira Lopes, organizadora, Belo Horizonte: Autêntica, 1998, pp. 107-149.

FERREIRA, A. B. H. Aurélio, Século XXI: o dicionário da língua portuguesa. Rio de Janeiro: Nova Fronteira, 1999.

FERRETTI, M. C. G. O sujeito na Psicanálise e na Educação. Estilos da Clínica: Revista sobre a infância com problemas. São Paulo, Pré-Escola Terapêutica Lugar de Vida, IPUSP, n. 3, 1997, pp. 58-63.

FILLOUX, J.-C. Psicanálise e Pedagogia ou: sobre considerar o inconsciente no campo pedagógico. Anais do I Colóquio do Laboratório de Estudos e Pesquisas Psicanalíticas e Educacionais sobre a Infância - FEUSP, 1999, pp. 9-42.

Psychanalyse e Éducation: repères. Études Psychotherapiques, Privat édition Toulouse, n. 3, set., 1985.

FILLOUX, J. Sur le concept de transfert dans le champ pédagogique. Revue Française de Pédagogie, n. 87, avril-mai-juin, 1989, pp. 59-75.

FLEIG, M. Transmissão e ensino da Psicanálise: os impasses e seduções da Universidade. Correio da APPOA, Porto Alegre: n. 61, set. 1998, pp. 29-35.

FOUCAULT, M. A arqueologia do saber. Rio de Janeiro: Forense Universitária, 2004. 
- Problematização do sujeito: psicologia, psiquiatria e psicanálise. Organização Manoel Barros da Motta. Rio de Janeiro: Forense Universitária, 1999.

FREUD, S. (1900) A interpretação de sonhos (Parte I e II). Coleção Standard Brasileira das Obras Psicológicas Completas de Sigmund Freud. Rio de Janeiro: Imago, vols. IV e V, 1988.

ESB, VII, 1988.

(1905) Fragmento de análise de um caso de histeria (Posfácio).

. (1905) Três ensaios sobre a teoria da sexualidade. ESB, VII, 1988.

. (1907) O esclarecimento sexual das crianças. ESB, IX, 1988.

1970.

. (1910) As perspectivas futuras da terapêutica psicanalítica. ESB, XI,

. (1914) A história do movimento psicanalítico. ESB, XIV, 1988.

1995.

. (1914) Algumas reflexões sobre a Psicologia do escolar. ESB, XIII,

. (1915) Reflexões sobre os tempos de guerra e morte. ESB, XIV, 1988.

. (1919 [1918]) Sobre o ensino da Psicanálise nas universidades. ESB, XVII, 1988.

. (1921) Psicologia de grupo e a análise do ego. ESB, XVIII, 1988.

. (1924) Um estudo autobiográfico. ESB, XX, 1988.

1988.

. (1925) Prefácio à Juventude desorientada de Aichhorn. ESB, XIX,

. (1930) O mal-estar na civilização. ESB, XXI, 1988.

$\overline{X X I I, 1988 . ~}$

(1933) Novas conferências introdutórias sobre Psicanálise. ESB,

. (1938) Algumas lições elementares de Psicanálise. ESB, XXIII,

1988.

Cartas entre Freud \& Pfister (1909 - 1939). Viçosa: Ultimato, 1998.

1995.

(1895) Projeto de uma Psicologia Científica. Rio de Janeiro: Imago, 
GAY, P. Freud: uma vida para o nosso tempo. São Paulo: Companhia das Letras, 1989.

HANNS, L. A. Psicoterapias sob suspeita - a Psicanálise no século XXI. In: Ciência, pesquisa, representação e realidade. Raul A. Pacheco Filho, Nelson Coelho Júnior e Miriam D. Rosa (orgs). São Paulo: Casa do Psicólogo: EDUC, 2000, pp. 175-203.

HOFFMANN, C. A proposito de la función del "mas uno" en el cartel. Darle a la Lata del Cartel. Recompilação de textos acerca do cartel. Biblioteca de Psicoanalisis Oscar Masotta, 1985.

IMBERT, F. A questão da ética no campo educativo. Petrópolis, R.J.: Vozes, 2001.

JAPIASSU, H. Psicanálise: ciência ou contraciência? Rio de Janeiro: Imago Ed., 1998.

JONES, E. Vida e obra de Sigmund Freud. Rio de Janeiro: Zahar Editores, 1979.

KUPFER, M. C. M. Educação para o futuro: psicanálise e educação. São Paulo: Escuta, 2001.

LACAN, J. Seminário, livro 5: as formações do inconsciente (1957-1958). Rio de Janeiro: Jorge Zahar Ed., 1999.

Seminário, livro 17: o avesso da Psicanálise (1969-1970). Rio de Janeiro: Jorge Zahar Ed., 1992.

Escritos. São Paulo: Perspectiva, 1978.

LAJONQUIÈRE, L. de. Epistemologia e Psicanálise: o estatuto do sujeito. In: Percurso: Revista de Psicanálise, Ano VII, n. $13,2^{\circ}$ semestre de 1994, pp. 57-63.

- Infância e ilusão (psico)pedagógica: escritos de psicanálise e educação. Petrópolis, R.J.: Editora Vozes, 1999.

O esgotamento da infância e a educação. Insight: Psicoterapia $e$ Psicanálise. Ano XI, n. 121, setembro/2001, pp. 12-17.

Sigmund Freud, a educação e as crianças. Estilos da Clínica: Revista sobre a infância com problemas. São Paulo, Pré-Escola Terapêutica Lugar de Vida, IPUSP, n. 12, 2002, pp. 112-129.

LALANDE, A. Vocabulário técnico e crítico da filosofia. São Paulo: Martins Fontes, 1999. 
LAPLANCHE, J.; PONTALIS, J.-B. Vocabulário da Psicanálise. São Paulo: Martins Fontes, 1970.

LAPLANCHE, J. O inconsciente e o id - Problemáticas IV. São Paulo: Martins Fontes, 1992.

A tina: a transcendência da transferência - Problemáticas $V$. São Paulo: Martins Fontes, 1993.

LELLO, J.; LELLO, E. Dicionário prático ilustrado. Porto: Lello \& Irmão, 1966.

LO BIANCO, A. C. Freud: entre o movimento romântico e o pensamento científico do século XIX. Psychê: Revista de Psicanálise. São Paulo: Unimarco Editora, ano VI, n. 10, jul-dez/2002, pp. 149-160.

LOPES, E. M. T. A educação (não) é tudo. Estilos da Clínica: Revista sobre a infância com problemas. São Paulo, Pré-Escola Terapêutica Lugar de Vida, IPUSP, n. 15, 2003, pp. 112-123.

MAHONY, P. J. Psicanálise e discurso. Rio de Janeiro: Imago Ed., 1987. Sobre a definição do discurso de Freud. Rio de Janeiro: Imago Ed., 1990.

MANNONI, M. Um saber que não se sabe: a experiência analítica. Campinas, S.P.: Papirus, 1989.

MANNONI, O. Un comienzo que no termina: transferencia, interpretacion, teoria. Barcelona - Buenos Aires: Ed. Paidos, 1982.

MARINHO, N. C. Discussão da racionalidade da teoria psicanalítica a partir da epistemologia de Karl Popper: avaliações - impasses - alternativas. Dissertação (Mestrado em Filosofia). Departamento de Filosofia da Pontifícia Universidade católica do Rio de Janeiro, 2001.

MASSON, J. F. Correspondência completa de Sigmund Freud e Wilhelm Fliess - 1887-1901. Rio de Janeiro: Imago, 1986.

MENDONÇA, A. L. O.; VIDEIRA, A. A. P. A revolução de Kuhn. Revista Ciência Hoje, n. 189, vol. 32, dez./2002, pp. 77-79.

MEZAN, R. Interfaces da Psicanálise. São Paulo: Companhia das Letras, 2002.

Brasiliense, 1988.

. A vingança da esfinge: ensaios de Psicanálise. São Paulo: Ed. MILLOT, C. Freud Antipedagogo. Rio de Janeiro: Jorge Zahar Editor, 1995. 
MONTEIRO, E. A. A transferência e a ação educativa. Dissertação (Mestrado em Educação). Faculdade de Educação da Universidade de São Paulo, 2000.

MONZANI, L. R. Discurso filosófico e discurso psicanalítico. Prado Jr, B. (org.) Filosofia da Psicanálise. São Paulo: Ed. Brasiliense, 1991, pp. 73-107.

NASIO, J.-D. O valor da transmissão (entrevista). Percurso: Revista de Psicanálise, n. 26, 2001, pp. 93-101.

OLIVEIRA, C. L. M. V. de. Os primeiros tempos da Psicanálise no Brasil e as teses pansexualistas na Educação. Ágora: Estudos em Teoria Psicanalítica, Programa de Pós-Graduação em Teoria Psicanalítica do Instituto de Psicologia da UFRJ, vol. V, n. 1, jan./jun. de 2002, pp. 133-154.

PACHECO FILHO, R. A. O método de Freud para produzir conhecimento: revolução na investigação dos fenômenos psíquicos? In: Ciência, pesquisa, representação e realidade. Raul A. Pacheco Filho, Nelson Coelho Júnior e Miriam D. Rosa (orgs). São Paulo: Casa do Psicólogo: EDUC, 2000, pp. 235270.

PASSOS, C. L. R. V. A transferência: um percurso na teoria. Dizer: Boletim da Escola Lacaniana de Psicanálise. Rio de Janeiro: junho de 1991, n. 4, pp. 65-73.

PEREIRA, M. R. O avesso do modelo: bons professores à luz da Psicanálise. Dissertação (Mestrado em Educação). Faculdade de Educação da Universidade Federal de Minas Gerais, 1998.

Amor e rigor: ou o que pode dizer a psicanálise sobre o documentário "Ser e Ter". Estilos da Clínica [online]. 2005, vol.10, n.18, pp. 12-23.

PIMENTA, S .G. (org.) Pedagogia e pedagogos: caminhos e perspectivas. São Paulo: Cortez, 2002a.

PIMENTA, S. G.; GHEDIN, E. (orgs.) Professor reflexivo no Brasil: gênese e crítica de um conceito. São Paulo: Cortez, 2002b.

PINTO, J. M. Psicanálise e ciência - o sujeito da Ciência como ponto de estruturação interna da Psicanálise. In: Ciência, pesquisa, representação e realidade. Raul A. Pacheco Filho, Nelson Coelho Júnior e Miriam D. Rosa (orgs). São Paulo: Casa do Psicólogo: EDUC, 2000, pp. 165-173.

POPPER, K. Conjecturas e refutações. Brasília: Ed. Universidade de Brasília, 1972.

RABINOVICH, D. S. O psicanalista entre o mestre e o pedagogo. Boletin da Escola Lacaniana de Psicanálise - Dizer 4. Rio de Janeiro, junho de 1991, pp. 7-31. 
RANCIÈRE, J. O mestre ignorante. Belo Horizonte: Autêntica, 2004.

ROLIM, A. M. A. A Psicanálise é uma ciência: mas quem não se importa? Revista Psicologia Ciência e Profissão. Ano 20, n. 2, 2000, pp. 8-11.

ROMERA, M. L. C. Ensino-transmissão da Psicanálise: Ser ou Não ser...Algo Mais?! Jornal de Psicanálise, Instituto de Psicanálise - SBPSP, São Paulo, vol. 27, n. 51, 1994, pp. 51-62.

ROUDINESCO, E.; PLON, M. Dicionário de Psicanálise. Rio de Janeiro: Jorge Zahar Ed., 1998.

ROUDINESCO, E. Por que a Psicanálise? Rio de Janeiro: Jorge Zahar Editor, 2000. . História da Psicanálise na França: a batalha dos cem anos, volume 2: 1925-1985. Rio de Janeiro: Jorge Zahar Ed., 1988.

Maspero, 1977.

Pour une politique de la Psychanalyse. Paris: François

RUSSELL, B. História do pensamento ocidental: a aventura dos présocráticos a Wittgenstein. Rio de Janeiro: Ediouro, 2001.

SAFOUAN, M.; JULIEN, P.; HOFFMAN, C. O mal-estar na Psicanálise: o terceiro na instituição e a análise de controle. Campinas, S.P.: Papirus, 1996.

SAPORITI, E. A Cientificidade da Psicanálise: Popper e Peirce. São Paulo: Editora Escuta, 1994.

SILVA, F.L. Descartes: a metafísica da modernidade. São Paulo: Moderna, 1996.

TURATO, E. R. Tratado de metodologia da pesquisa clínico-qualitativa: construção teórico-epistemológica, discussão comparada e aplicação nas áreas da saúde e humanas. Petrópolis, RJ: Vozes, 2003.

VALE, E. A. N. do. Os rumos da Psicanálise no Brasil. Dissertação (Mestrado em Psicologia). Instituto de Psicologia da Universidade de São Paulo, 1986.

VOLTOLINI, R. As vicissitudes da transmissão da psicanálise a educadores. Anais do III Colóquio do Laboratório de Estudos e Pesquisas Psicanalíticas e Educacionais sobre a Infância - FEUSP. São Paulo: Scielo, 2001.

ZUMTHOR, P. Correspondência de Abelardo e Heloísa. São Paulo: Martins Fontes, 2000. 